Historic, Archive Document

Do not assume content reflects current scientific knowledge, policies, or practices. 



\section{MICHA EL}
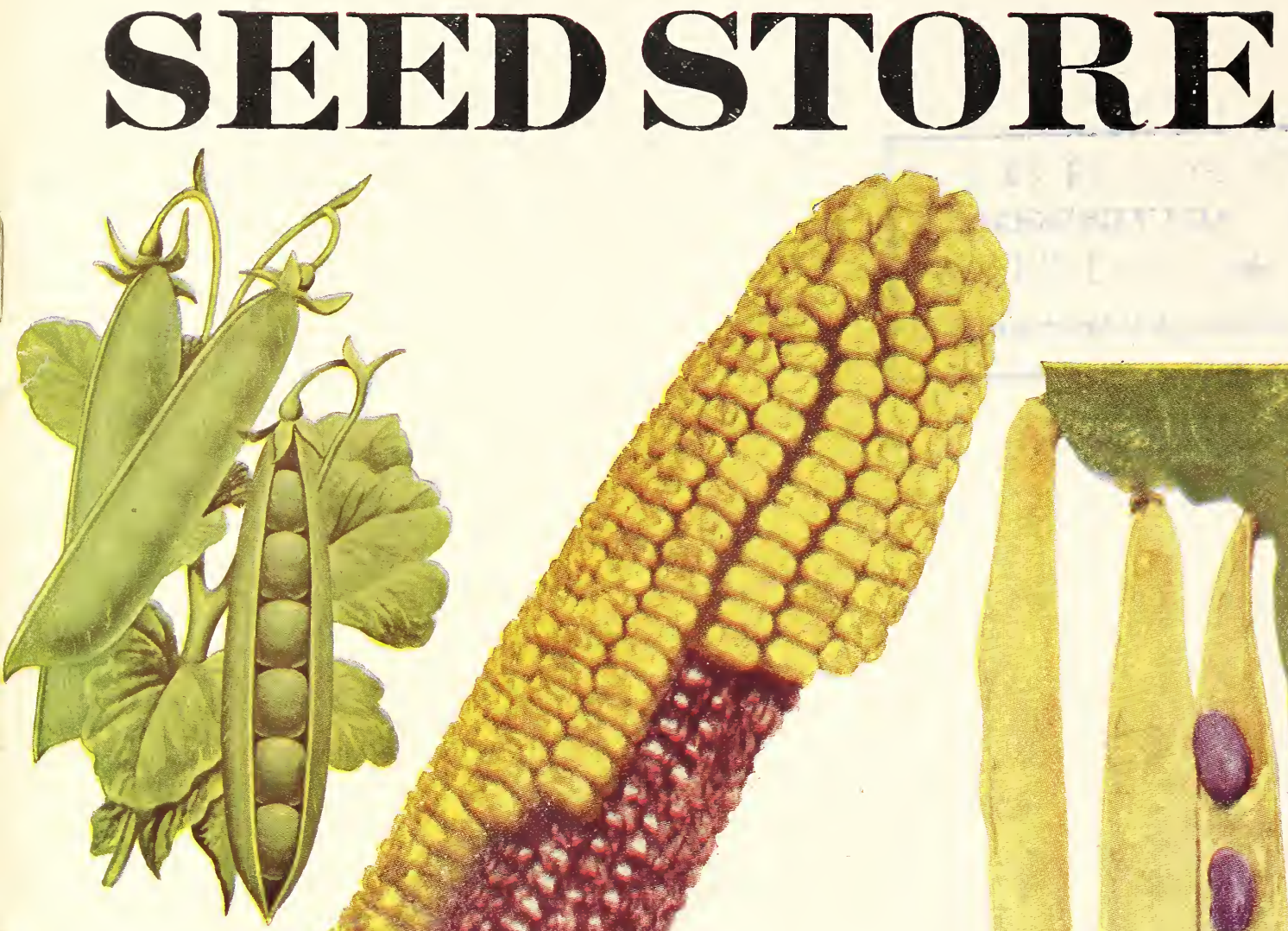

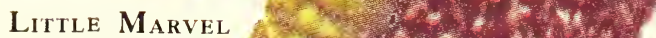

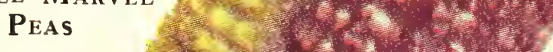

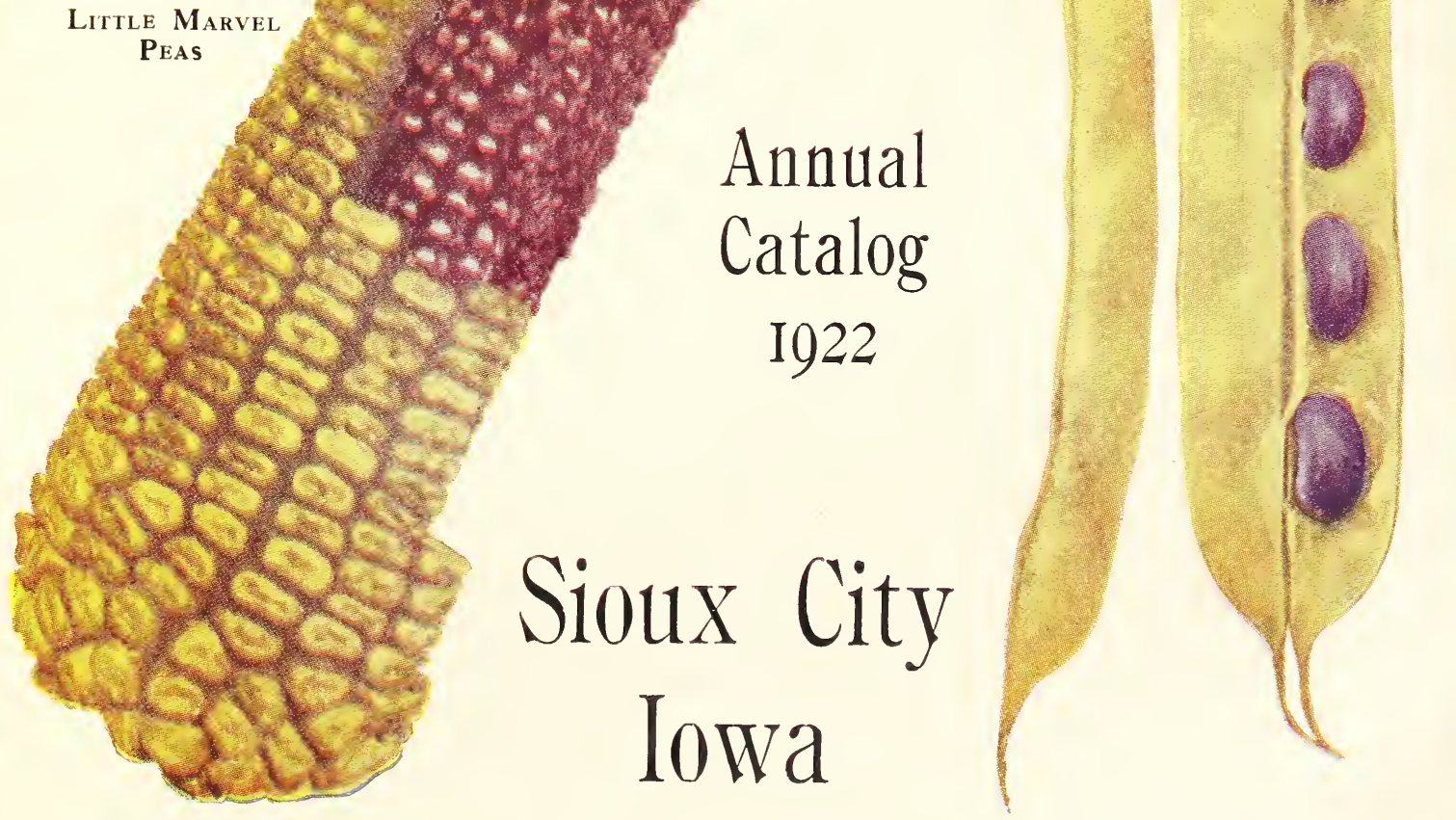

Pride of Minnesota

See Page 24

Royal Purple

WAX BEAN 


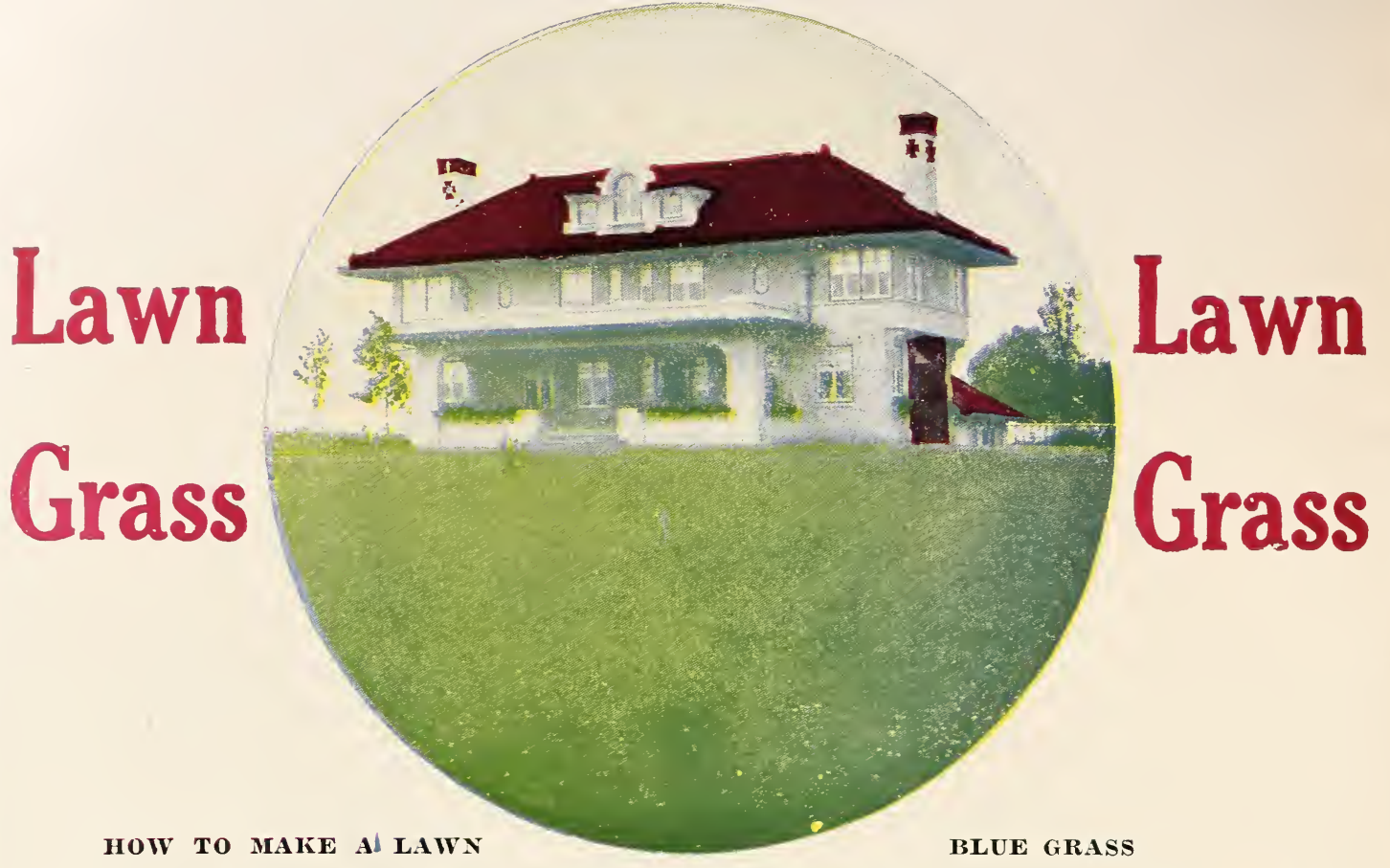

In preparing a seed bed so as to insure an everlasting lawn it is well that the earth be stirred deeper than merely scratching the surface, either with a good stirring plow or spaded to the depth of a foot or fifteen inches of eren more. This is the first step to be taken, and the next consideration is the fertility of the soil where you are making the lawn. Among the various methods which increase the fertility of the soil we find that Humus plays a most important part. Humus and organic matter such as barn manure, well rotted and pulverized or Bog Peat, well mixed in the soil when plowed or spaded has the effect to keep it sweet and porous. Aside from this fertilizing feature, humus- increases the capacity of the soil to retain moisture, an important feature in the verdant effect of a relvety lawn. Raw Ground Lime or Land Plaster (Cal. Sulphate) can be added to advantage and a coat of either of these 100 pounds to every 1.000 square feet is highly beneficial and the effect is lasting and permanent. The very best time to do the work of preparing the soil for a lawn is in the autumn season and then left for the winter. The soil is solidified by the winter condition. Then in the spring the surface should be lightly stirred and the seed sown, well raked in and rolled. When the summer is over and the winter comes on again, the lawn needs attention and it is a wise plan after the ground is slightly frozen to cover it with a moderate coat of well rotted manure. In the springtime before the growth of grass is started, this coat of manure should be well raked in the soil, and the roughage raked off, giving the grass a chance to get plenty of sunlight. Should, howerer, this be overlooked in the autumn, then in the springtime again it is well to apply a moderate amount of sheep manure, phosphate, or ground bone fertilizer, well raked into the soil just as soon as is possible and at such time it is well to apply a sprinkle of our blend of reseeding lawn grass.

These suggestions in regard to the making of a lawn will well repay the time and expense by the increased growth of grass.

\section{DEFP ROOTED LAWN GRASS}

This is a blend of strong, powerful rooted grasses. It is especially valuable and is blended on purpose for just such places where we have had trouble to get sod firmly set. Shady nooks, terraces, slopes, sun-baked corners, and other trying places difficult to get a catch and sod started with those velvety foliage surface rooted grasses. In these places Deep Rooted Lawn Grass planted early in the spring time with some good fertilizer well mixed in the soil brings the desired results. Per 1b., 50c.

WHITE CLOVER SEED. 60 per $1 \mathrm{~b}$.

FERTILIZERS. See page 43 . 


\section{THE MICHAEL SEED STORE}

Auto Phone 2142 New Phone 935-M

316 E. Pearl St., SIOUX CITY, IOWA.

\section{INDEX}

\section{VEGETABLE SEEDS}

Beans

Peas

Sweet

Mangel, Sugar Beets 5

Cabbage …..............5, 6

Cauliflower .................. 5

Carrots ............................

Celery

Cucumber

Lettuce

Muskmelons ................ \&

Mushroom Spawn ......14

Watermelons ........... ?

Onions ….................. 10

Onion Sets ...................10

Pepper ….....................11

Parsnip ........................12

Pumpkin .....................12

Radish ……................11

Spinach ….....................12

Squash
Tomatoes

Turnips ........................13

Miscellaneous

Vegetables

Herb Seeds

FLOWFR SEEDS

Flower Seed (Bulk) 15 Sweet Peas ................ 1s Nasturtium ....................1S

\section{ROOTS, BULBS,} PLANTS

Iris

Canna Roots

House Plants

Gladiolus

Conservatory Plants

Hardy Bulb Roots ....27

Tender Bulb Roots 27

Dahlia

Peonies

Iilies

Ferns, Hardy

Autumn Bulbs ..............28

Hanging Baskets ......29

Flowering Plants ...29

Vegetable Plants …...29

Vegetable roots ........29

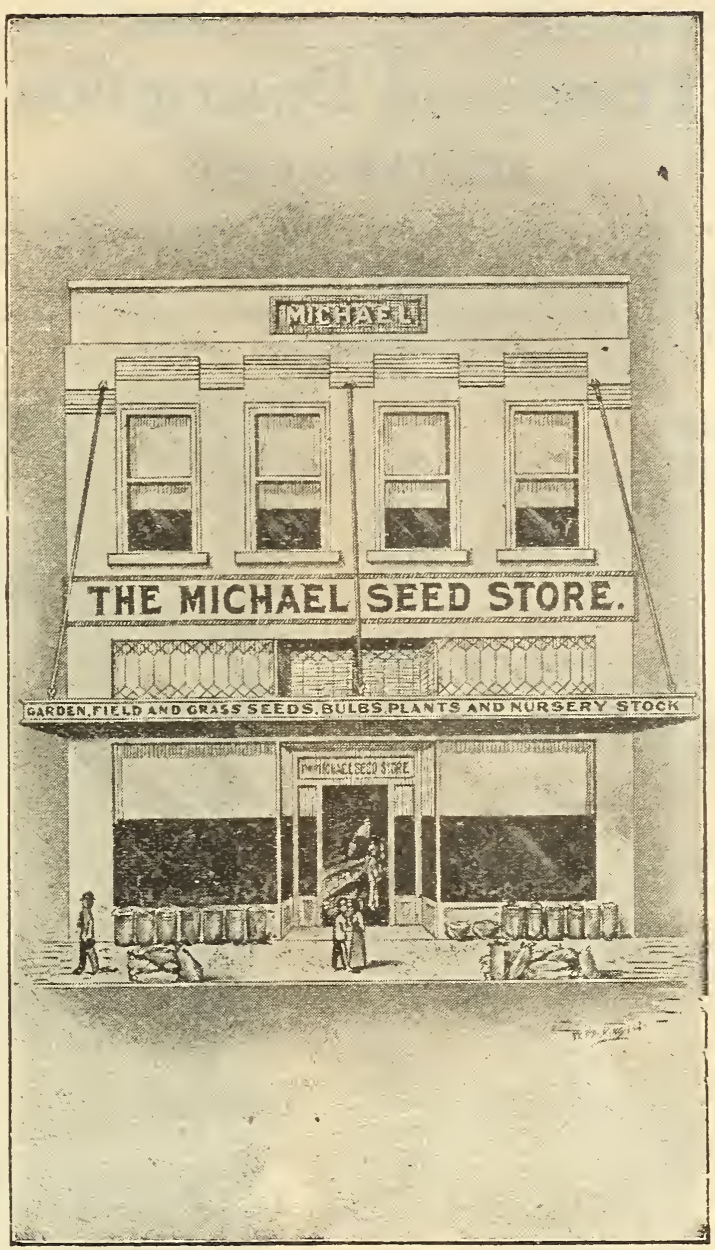

THE HOME OF GOOD SEEDS

Bulbs, Plants and Nursery Stock

\section{INDEX}

GRASS SEEDS

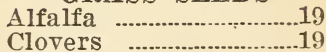

Sweet Clover ...............19

Bromus Inermis .....20

Ky. Blue Grass ..........20

Eng. Blue Grass ........20

Orchard Grass ..........20

Rye Grass ....................20

Timothy . 20

Cane Seed …...............23

Millet …….....................21

Sudan Grass ...............21

Feterita .........................22

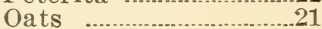

Rye

Barley

Speltz

Flax

Potatoes

Rape

Cowpeas

Buckwheat

Seed Corn

Wheat

Syrup Sorghum …....23

NURSERY DEPARTMENT

Apples ……........30, 31

Cherries ……...................

Currants .......................33

Plums

Pears …….......................32

Gooseberries …..............33

Buffalo Berries ........33

Grapes ……......................

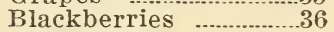

Raspberries …............36

Strawberry Plants ..34

Roses ................... 40, 41

Ornamental Shrubs 37

Ornamental Trees ...39

Shade Trees …...........39

Climbing Vines .......3s

Hedge Shrubs ............3S

Weeping Trees ….......39

Evergreens …................42

Seedlings ......................43

Insecticides …...............43

Fertilizers ….....................43

Pcultry Foods ........4t

Animal Foods .............4t

Sprayers …......................4t

Seeders

Garden Implements 44

Inoculations ..................44

\section{THE HOUSE THAT MICHAEL BUILT}

A FRIENDLY TIP: Plant a home garden this spring. It is a sure cure for spring fever, a healthful exercise and a swat at the High Cost of Living. This applies to the city man, the suburbanite and the farmer too. For the latter it is a boon. Any farmer can save \$500.00 a year with a good home garden.

CATALOG: in handing you our new catalog we wish to express our thanks and appreciation and good will in days gone by.

VEGETABLE AND FLOWER SEEDS: We carry a full line of these seeds and they are the best the country affords. Purest quality, of strong germination, grown and carefully selected for us by special growers; men who exercise the greatest care to have the seeds choice, pure and reliable.

CLOVER AND GRAss sEEDs: Our field and grass seeds are of superfine quality, extra recleaned, pure, free from foul and obnoxious weed seed as it is possible to render them by the best process of recleaning.

NURSERY STOCK: Our cellar arrangements for handling nursery stock surpasses anything in the country for keeping this stock in just as nice shape after it is dug up in the spring time and brought to our house as if it was just dug out of the ground when the purchaser comes to get it. We call your attention to page 30 for the Nursery Department.

DISCLAIMER: While we exercise the greatest care to have all seeds pure and reliable, it is positively understood we sell no seeds, plants, bulbs or nursery stock with any warranty expressed or implied in any respect and will not be in any way responsible for the crop. 


\section{The Michael Seed Store}

\section{J. S. MICHAEL, Manager \\ 316 Pearl Street, Sioux City, lowa \\ Auto Phone, 2142 \\ lowa Phone, 935-M \\ Prices and Description}

\section{VEGETABLE SEEDS}

BEANS, PEAS AND SWEET CORY come first-other SEEDS in alphabetical order.

NoticE-Prices quoted are f. o. b. Sioux City, Iowa. If ordered sent by mail, add 10c per pint, $15 \mathrm{c}$ per quart or $8 \mathrm{c}$ per pound to catalog prices.

Price per trade packet on seeds described below, except otherwise quoted: 8c each, 2 for 15c.

All prices quoted are subject to stocks on hand and market fluctuation.

\section{Beans}

Beans are very sensitive to both cold and wet. It would be useless to plant them until the ground is warm. They can be safely planted culture make Jour rows about 18 inches apart first when the apple is in bloom. For garden and $S$ inches apart in the rows. One quart plants about 100 foot rows.

Golden Wax The old standard wax sort. Prore and early with yellow Golden Wax also at same prices. Prices: $1 / 2$ lb., 25̃c; 1 lb., 25c; 10 lbs., \$2.00.

American Black Wax The old standard Black pods are round, brittle, of ax Bush Bean. The low color, and of buttery flaror when cooked. Prices: 1/2 1b., 15c; $1 \mathrm{lb.,} 25 \mathrm{c}$; 2 lbs., 45c; $10 \mathrm{lbs}$, \$2.00.

Davis White Wax A ner, white, rustless, productive, wax-podded bean; pods flat, very long, white waxy color, and handsome; seeds clear white. Price: 1/2 lb., 15c; 1 Ib., 25c; 10 Ibs., \$2.25.

Stringless Green Pod The earliest and hardiest arts : green podded measure six inches in length. Very productive, bearing profuseiy the beautiful green pods, perfectly round. straight, broad, tender, brittle, fleshy and entirely stringless. Price: $1 / 2$ 1b., 15e; 1 1b., 25c; 15 lbs., \$3.25.

Extra Early Round Pod Red Valentine $\begin{gathered}\text { For } \\ \text { Snaps }\end{gathered}$ there is nothing superior to this dwarf greenpodded sort, both for the lome and market garden. Many prefer it to the wax varieties. Pods medium length, curved cylindrical, with crease in back, Fery fleshr, crisp and tender. Price: 1/2 1b.. 15̃e; 1 lb., 25̃c; 15 lbs., $\$ 3.00$.

Improved Dwarf Lima A true bush form of ported by its own thick stems. Unsurpassed in productiveness and quality of its large, handsome pods. Price: 1/2 1b., 20e; 1 lb., 55e; 10 lbs., $\$ 3.50$.

Large White Lima Tine, tall growing, requires borne in clusters, long, broad, rery thin, dark green; seed very large, ova. flat, greenish white. Price: 1/2 1b., 15e; 1 1b., 30c; 10 1bs., \$2.50. Kentucky Wonder, or old Homestead. $\begin{gathered}\text { Pole } \\ \text { variety }\end{gathered}$ long, flat green pods, seren to nine inches in length, fleshy and stringless. Heary yielder. Excellent for snap beans. Price: $1 / 2$ lb., 15c; 1 lb., 30c; 10 lbs., \$2.50.

Field Bean White. The finest white field tions of the country. Price: 1 lb. 15c; 10 sec$\$ 1.00$; per 100 lbs., $\$ 800$. Bags extra.

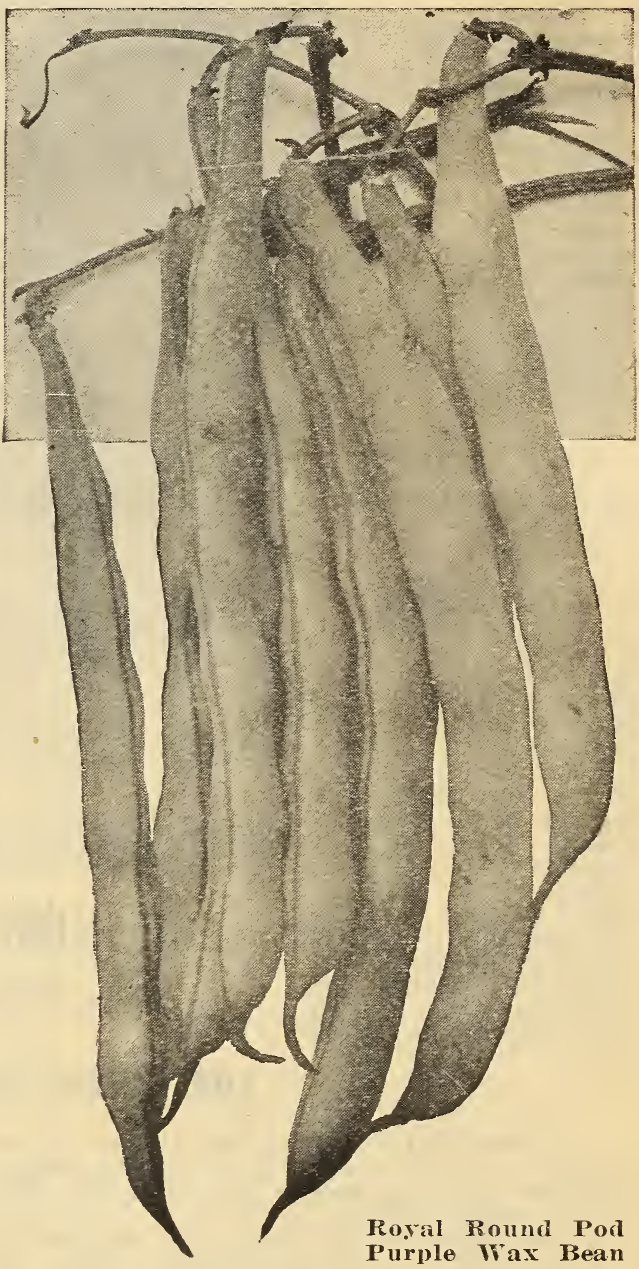

Royal Round Pod Purple Wax Bean We are this season as a specialty this splem offering bean. It has proven itself to be one of the very best of all the wax sorts. The plants are good size without runners; leaves are dark green. Pods are very round and deep yellow in color, very brittle, stringless, without fibre, and unsurpassed in quality. For the market gardener who wants a first class round podded wax bean, this is one of the best that has ever appeared. Price: $1 / 2$ 1b., 15c; 1 lb., 25c. 
Price per trade packet on seeds described below, except otherwise quoted: 5c each, 6 for $25 c$.

\section{PEAS}

Peas are among the earliest seeds that can be planted at the close of winter. The round, smooth sorts are the hardiest and are often planted without danger before the frost is out of the ground. The wrinkled sorts are not so hardy and cannot with safety be planted quite so early; but plant all kinds as early as possible and plant on a warm, quick, rich soil. Peas will mature earlier if planted only an inch deep. Where earliness is most important they should not be planted deeper. but larger pods and more of them may be had by deeper planting. Dwarf varieties are planted in rows 15 inches to 2 feet apart. Two quarts of seerls sow a hundred rards of rows.

Alaska or Earliest of All The rines are of of distinctive light color. The pods are of good size, about two and one half to two and threefouxths inches long. Seed small, smooth, and bluish green in color. This sort matures all of its crop at once and is an invaluable variety for market gardeners and canners. Price: $1 / 2$ lb., 15c; 1 lb., 25c; 10 lbs., \$2.00.

Ferry's First and Best The earliest and most even, extra early peas in existence, maturing well together. Price: 1/2 lb., 10c; 1 lb., 20c; 10 lbs., \$1.50.

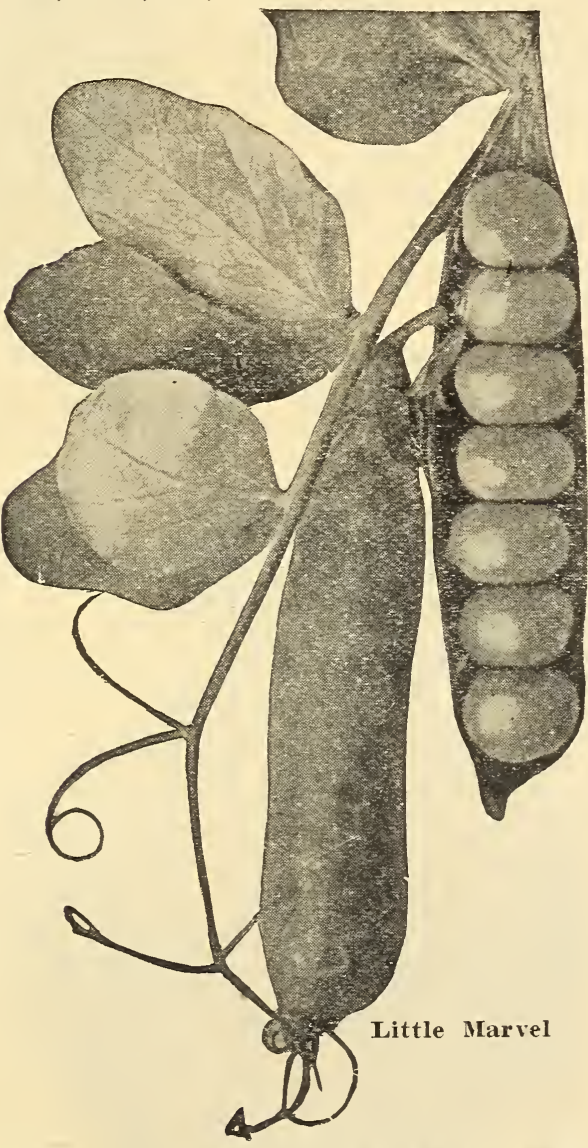

Little Marvel New improved variety lately inhome garden variety yet introduced, very early, large podded and a great cropper, 18 inches high, pods rery dark green, produced in pairs and glways well filled.Price: $1 / 2$ lb., 15c; 1 lb., $25 \mathrm{c}$.
Michael's Early June Pea This is actually the earliest pea known. Being a dented solid berry, it will stand planting two weeks earlier than the wrinkled varieties without injury from weather conditions which hardy quality gives it an extra early start. The berry is bluish green in color; vines grow about knee high and good averaged size pod; well filled and of a very rich quality. Price per $1 / 2$ lb., 15c; per 1b., 25c; 10 lbs., $\$ 2.00$.

American Wonder Somewhat similar to Nott's wrinkled nea; very dwarf. Pods quite large but not many to a vine. Price: 1/a lb., 15c; 1 1b., 25c; 10 lbs., \$2.25.

Little Gem Probably the best known and more widely grown second early. It comes in following the first earlies, grows about 15 to 18 inches high and bears heavily of large, plump pods. The peas are wrinkled and very sweet. Price: 1/2 lb., 15c; 1 lb., 30c; $10 \mathrm{lbs} ., \$ 2.50$.

Nott's Excelsior A rery sweet, very dwarf Nott's Excelsior early pea, small bush, about 15 inches high. Bears very heavily in a favorable season, but subject to weather conditions more than the smooth peas. Very high quality. Price: 1/2 lb., 15c; 1 lb., 25e; 10 lbs., $\$ 2.25$.

Harvester This handsome wrinkled pea is the largest of the dwarf varieties and almost identical with the Laxtonian. The pods are dark green, about four inches in length and of splendid quality; early in season; vines vigorous and productive; average 15 to 18 inches high. Price: 1/2 1b., 20c; 1 lb., 35c.

Telephone The Telephone is medium early in Telephone season, bears a long time; the pods are always of good size, well filled and the quality is of the very best. Price: $1 / 21$ lb., 15e; 1 $1 \mathrm{~b} ., 25 \mathrm{e} ; 10 \mathrm{lbs} ., \$ 2.00$.

Champion of England The best late season oldest rarieties of peas. There is no sweeter pea than the Champion of England. The vines grow almost 5 feet high, are very vigorous and produce a heavy crop of good sized pods filled from end to end with luscious peas. Price: $1 / 2$ lb., 15e; 1 lb., 25e; 10 lbs., \$2.25.

Marrowfat (Late) One of the oldest and best known peas. A great yielder of ordinary quality peas. Price: 1 lb., 20c: 10 lbs., \$1.75.

Edible Pod Pea This class of pea is but little brittle. succulent pod, and can be used same as snap beans, cooking both pod and pea together. Price: 1/2 1b., 15̃ ; 1 lb., 25e.

Canada Field Pea A splendid crop to sow with a crop and enrich the soil feed. Will produce a succeeds well almost anywhere same is very prolific. Price: 1 lb., 15c; 15 where and is very prolific. Price: 1 ib., $15 c$; 


\section{SWEET CORN}

DON'T PLANT SWEET CORN DEEP-Sweet Corn should not be planted over one inch deep; most people plant two or three inches deep-most sure to rot. Also do not plant too early... Not as early as field corn.

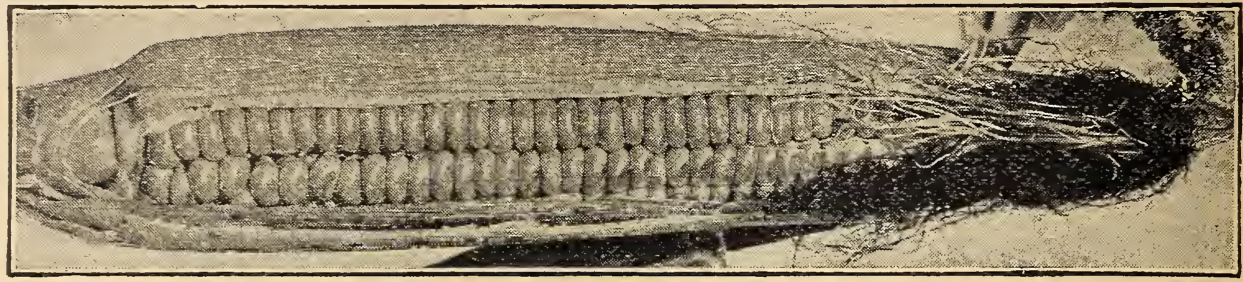

Dinner Bell

Dinner Bell This Sweet Corn for earliness surpasses anything yet introduced. It originated in North Dakota and while it is not as sweet as some of the later kinds it makes up for all this by coming in season so far ahead of them that it has served its purpose and gone before the others are ready to be used as green corn. The ears are not large but medium in size, pure white and of extra good quality for so early a corn. Price: 1/2 lb., 15c; 1 lb., 25c; 10 1bs., \$2.25. White Mexican Originated at Sioux City. Early Write Earlies and far sweeter than any of them. Price: 1 lb., 20c; 15 Ibs., \$1.75.

Golden Bantam A new variety of sweet corn: all corns. It may be planted thickly and as late as July 15 with splendid results for table use as green coln. Price: $1 / 2$ 1b., 10c; 1 lb., 15c; 15 lbs., $\$ 2.00$.

Extra Early Cory $\begin{aligned} & \text { Standard early sort, fair } \\ & \text { quality and very early. }\end{aligned}$

Price: 1 1b., 15̃c.
Minnesota Early The best and most popular of the older varieties. The stalks are short and bear two iong ears each, having eight rows of very sweet and tender kernels. Price: 1/2 1b., 10c; 1 lb., 15c; 15 lbs., \$2.00.

Country Gentleman This variety frequently while the average is three to a stalk. The cob is very small, giving good kernels of pearly whiteness. It is without doubt the sweetest and most tender of all sweet corn. Price: 1/2 lb. 10c; 1 lb., 20c; 10 1bs., \$1.75.

Stowell's Evergreen The standard big late and solid, and heavy yielder. Used extensively by the canning factories and for drying. Stays green and tender for a long time. Select hand picked stock. Price: $1 / 2$ lb., 10c; 1 lb., 15c; 10 lbs., \$1.40.

Sweet Corn for Fodder Good vitality; early plication.

\section{TABLE BEETS}

For earliest use sow seed of any round sort. Seed for main crop may be sown as soon as the ground can be gotten in proper condition. For table beets sow in drills 18 inches apart, and thin to stand 3 to 4 inches apart in the row. Use 1 ounce to 200 feet of drill and cover lightly; 5 to $6 \mathrm{lbs}$. per acre. Round and turnip shaped beets are best for spring and summer; the half long kinds for winter. For sugar beets and mangels make the rows $2 \frac{1}{2}$ to 3 feet apart, and sow 6 to 8 pounds per acre. A light, loamy soil is best for all beets. Extra Early Flat Egyptian $\underset{\text { The }}{\text { An }}$ tops are smali and the beets are round on top, but flat at bottom end. The color of flesh is light red. Price: oz., 10c; 1/4 1b., 25c; 1/2 1b., 35c; 1b., 50c.

Crosby's Egyptian A variety of beet which has Crosby's Egyptian nearly supplanted the orig. inal Egyptian and is more desirable because of its shape and fine quality. It is extremely early. Price: oz., 10c; 1/4 lb., 25c; 1/2 lb., 40c; 1b., 65̃c.

Early Blood Turnip A fine specimen of Blood good for summer and autumn use. Price: oz. $10 \mathrm{c} ; 1 / 4 \mathrm{lb}$., 20c; 1/2 1b., 30c; 1b., 50c.

Swiss Chard, or Spinach Beet The leaves of used as greens, cooked in same manner as Spinach and the large ribs are prepared like Asparagus, in which manner they are delicious. Price: oz. 10c.

Half Long Blood Dark Red flesh. Price: oz. Long Smooth Dark Blood Price: oz., 10c; Ib. 50c.
Detroit Dark Red A grand beet with tops exceptionally small and upright; roots are perfect turnip shape with small tap root. Color dark blood red. One of the best for market gardener and the home gardener. Price: 1 oz., 10c; $1 / 4$ lb., 25c; $1 / 2$ 1b., 35c; 1 lb. $2 n$.

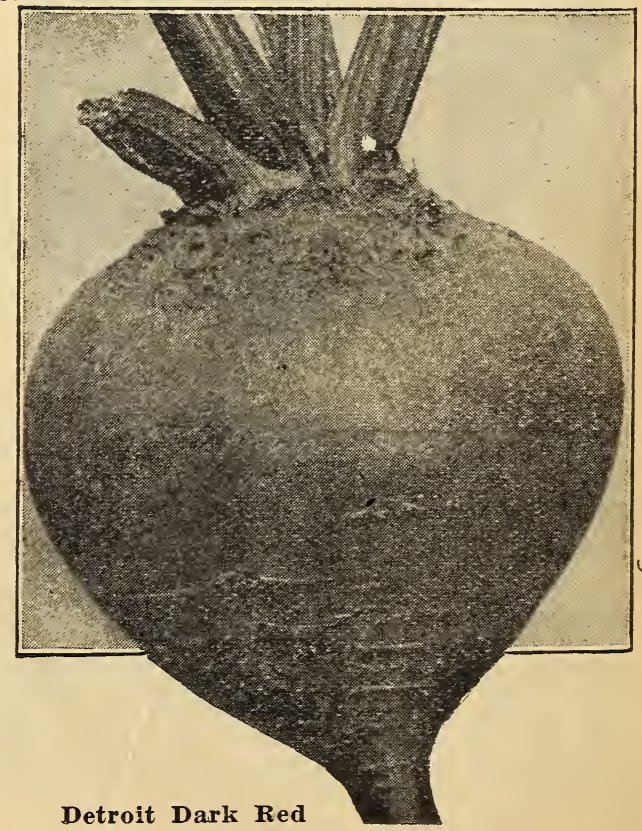


Priqu per trade packet on seeds described below, except otherwise quoted: 5c each, 6 for 25 c.

\section{Half Sugar Mangel Wurzel}

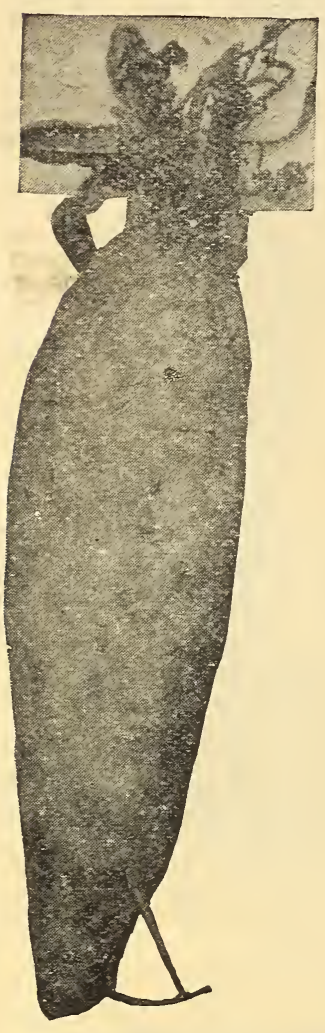

\section{Sugar Beets}

Sugar Beets may be grown in any tillable soil that is capable of producing good crops of regetables. A few rows of Sugar Beets in the garden will be sufficient for a supply of syrup for home use. A bushel of Sugar Beets will produce about a gallon of syrup. Splendid for stock food.

White French Sugar Price: oz., 10c; 1/4 1b.,

Write for U. S. Department of Agriculture for Farm Bulletin No. 823.

\section{Cauliflower}

One ounce of seed will produce about 3,000 plants.

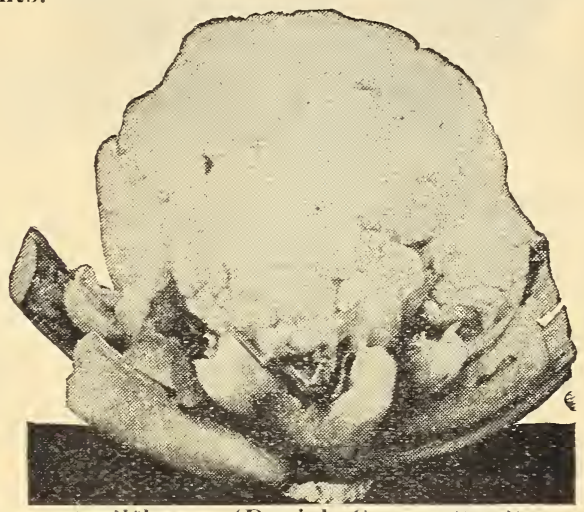

Cauliflower (Danish Grown seed)

Early Snowball Esteemed for its earliness and ing large, solid, pure white heads; dwarf in labit and as early as any; one of the best sorts for forcing. Price: Pkt., 15c; $1 / 4$ oz., \$1.00; 1/2 oz., \$1.50; oz., \$2.50.

Danish Giant One of the finest late varieties compact and thoroughly protected by leares. Price: pkt., 15c; $1 / 4$ oz., $80 \mathrm{c} ; 1 / 2$ oz., $\$ 1.50 ;$ oz., $\$ 2.50$.

CABBAGE

Culture. The Cabbage is a great feeder and well repays heavy manuring and high culture. It succeeds best on well drained soil. Early cabbage may be started in early spring in a hotbed. For main crop, summer and autumn cabbage, the seed should be sown in a rich bed in the open air in May or June. Sow shallow; $1 \mathrm{oz}$. of seed to 4,000 plants, 3 to 4 ozs. for an acre. Set the plants 2 to 3 feet apart each way. Give frequent cultivation.

Early Spring Cabbage The earliest flat head. Wakefield. Yields more than the early pointed heads. Solid, uniform and finely grained. Price: 1/2 oz., 15̃; oz., 25e.

Early Jersey Wakefield Considered by many Early Jersey Wakefield gardeners the very best early variety. Of large size for so early a kind. Heads hard and solid, and have few outside leaves. Our seed is extra select highest quality. American grown. Price: 1/2 oz., 10c; oz., 20c.

Winningstadt Cone-shaped summer sort; a Winningstadt sure header and a good keeper. Price: 1/2 oz., 15c; oz., 25c.

Danish Ball-Head (120 days) (Dutch Winter or Hollander). The heads are of medium size, solid and deep, averaging in weight nearly eight pounds. Their quality is superior and they are just as solid in spring as when put away in the fall. Price: 1/2 oz., 10c; oz., 20c; $1 / 4$ lb., 75c; 1 b.. $\$ 2.50$.

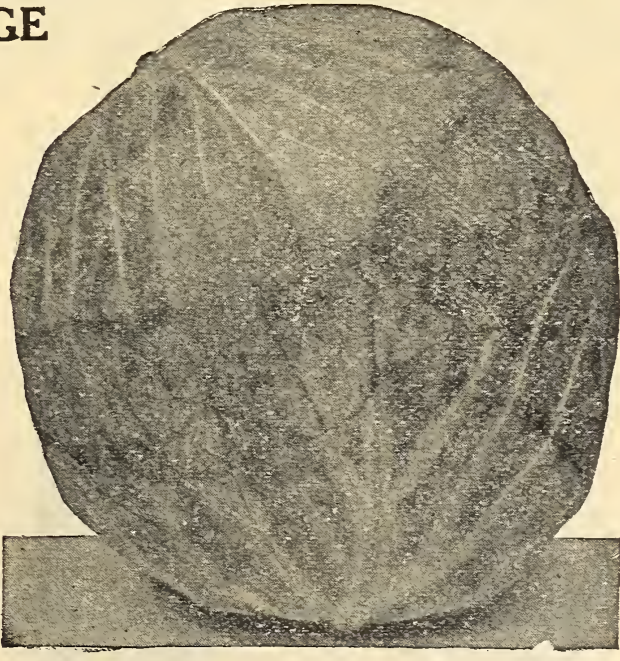

\section{New Early Cabbage}

Copenhagen An entirely new type of early Wakefield, as large as All Head, solider and better quality than either. Price: 1/2 oz., 15c; oz., 25c; 1/4 lb., 75c; 1b., \$2.50. 


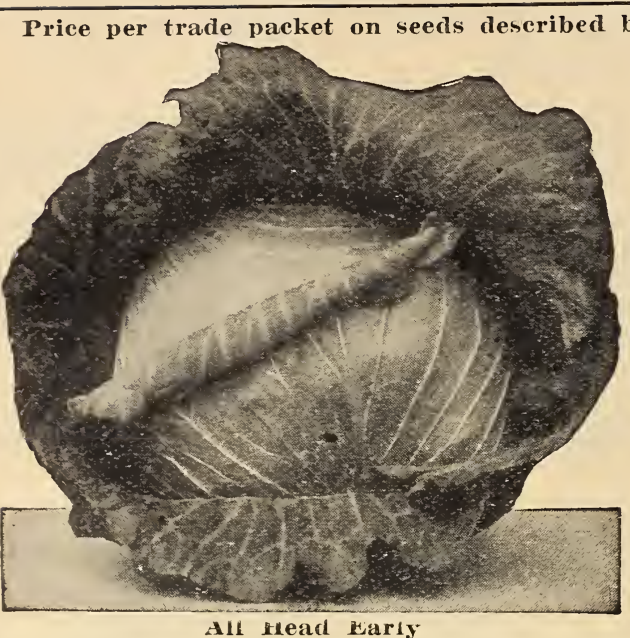

All Head Early All Head Early is of special herence to the type in habit of growth and the shape and quality of the head. Head large, very solid and flat. Quality excellent. By planting late it can be used also as a winter cabbage. Price: 1/2 oz., 10c; oz., 20c; 1/4 1b., 75e.

Early Flat Dutch Cabbage A valuable second good size, solid heads; sells well and are good keepers. Price: 1/2 oz., 10c; oz., 20c; 1/4 lb., \%̃c.

Henderson's Early Summer An excellent secSame as All Head. Price: See All Head.

Henderson's Succession An excellent variety maturing in midsummer. ${ }^{2}$ Same as All head. Price: See All Head.

Premium Late Flat Dutch This old and wellstill the standard winter kind. Heads large, solid and first-class keeper. Price: 1/2 oz., 10e; oz., 20c; 1 b., \$2.50.

Late Drumhead A very deep, solid, sure heading variety, which in rich soil will orow to a very large size; solid and excellent flavor. Price: $1 / 2$ oz., 15e; oz., 25e; 1b., $\$ 2.75$.

Haco The earliest of all Red Cabbage... The good red color to the center. Price: $1 / 2$ oz., 50e; oz., ซ5c.

For Cabbage Plants see page 21.

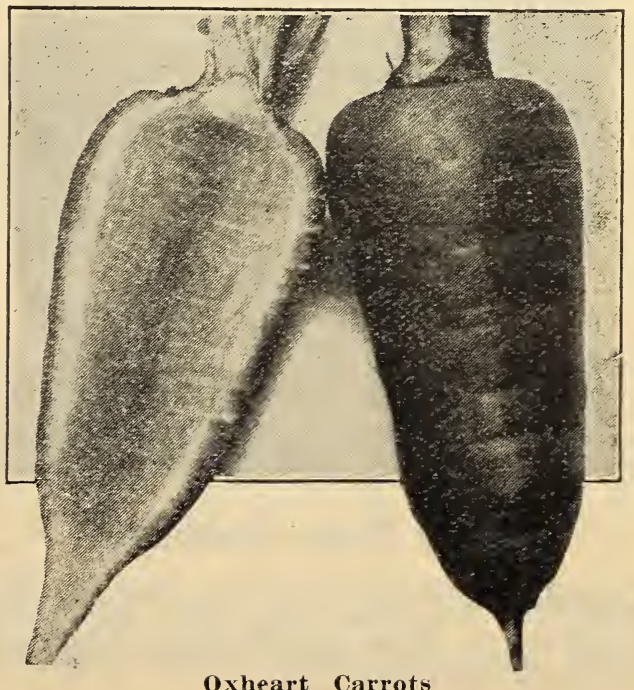

Oxheart Carrots

\section{CARROTS}

Carrots require a deep, well worked soil. Plant in rows 15 inches apart for table sorts; cover $1 / 2$ inch deep. One ounce plants 50 feet. Carrots are excellent for stock, especially for horses. Sow any time before July 1 st in rows 24 inches apart. Thin to 6 inches in the rows; two pounds of seed to the acre. Store in winter the same as turnips. For feeding stock grow the White or Yellow Belgian, which yields big crops.

Oxheart or Guerande We do not hesitate to call this the most valutween the Half Long and Horn rarieties, attaining a diameter of 3 to 4 inches at the neck, of beautiful shape and rich orange color. It is excellent for hogs and other live stock and has yielded 1,200 bushels per acre. Price: oz., 10c; $1 / 4$ ib., 35e; 1 b., $\$ 1.00$.

Earliest Short Horn (French Forcing). This Earhest Short Horn rariety is small, reddishorange, of globular shape and excellent flavor. Price: oz., 10̃c: 3 ozs., 35c; 1/2 1b., 75c; 1b., \$1.50. Danvers Half Long A popular standard racolor. Very smooth and handsome. In form halfway between Oxheart and the Long Orange, and wonderfully productive. Price: oz., 10c; 1/4 1b., 25c; 1b., ซ5c.

Chantenay Half-Long Resembling the Danvers, Medium early and heary cropper. Price: oz. $10 c ; 1 / 41 b ., 25 c ; 1 b ., 75 c$.

Improved Long Orange A well-known sort, near the roots long, thickset point, color deep orange. Price: oz., 10c; 2 oz., $15 \mathrm{c} ; 1 / 2$ 1b., 40c; $1 \mathrm{~b} ., 75 \mathrm{c}$.

Large Yellow Belgian Used for feeding cattle; productive. Price: oz., 10e; 1/4 lb., 25e; 1 lb., 75e; 5 lbs., \$3.00.

\section{Celery}

one ounce will produce 5,000 plants.

Celery... Celery seed is slow to germinate and ample time must be given. Sow thinly and cover lightly keep constantly moist. Count on about 4,000 plants per ounce of seed. WThen the seedling plants are 3 inches high they should be clipped at the top. Favor stock growth or lse transplanted.

\section{White Plume}

\section{Celery}

The earliest celery. The easiest to grow, as it blanches without oz., 10c; oz., 15c.

Giant Pascal A superior keeping sort. The crisp and of rich nutty flaror it blanches rery easily and retains its freshness a long time. Price: $1 / 2$ oz., 10c; oz., 15́c.

Golden Self Blanching The leading early raGolden Self Blanching riety. Stalks are broadsuperior in quality, while it is only a little later. Price: 1/2 oz., 15c; oz., 25c; 1b., \$2.50. 


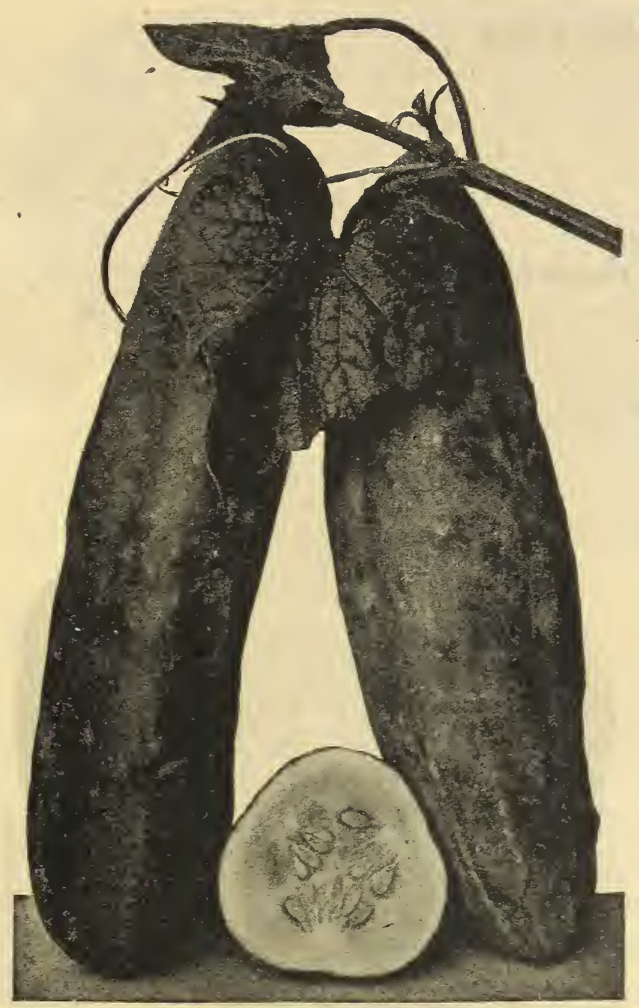

The Davis Perfect Cucumber

\section{CUCUMBERS}

Cucumbers thrive best on warm, rich, sandy soil, the richer the better. Crop should never be planted until soil is warm and the trees are out in full leaf. Plant in hills 4 feet apart and thin to about 4 plants to the hill. Second planting about the middle of July for fall. One ounce for 50 hills.

The Davis Perfect Cucumber An excellent new both outdoor use and forcing. It is a most carefully selected strain of the White Spine type. It is slim, slightly pointed, a dark glossy green color, very tender, brittle and of fine flavor, vigorous grower, withstanding blight and disease better than other sorts. Price: oz., 15c; 3 ozs., 35c; 1b., \$1.75.

Improved Early White Spine An excellent vaduces an early crop of straight, light green, with white spines. Price: oz., 10c; 3 ozs., 25c; 1b., \$1.25.

Early Cluster Vine vigorous, producing the and in bulk of the crop near the root thick end, dark green, but paler at blossom end. $A$ hardy and very productive sort. Price: oz., 10c; 3 ozs., 25c; 1b., $\$ 1.25$.

Early Frame Short Green This variety is an for table use and for pickling. Plants very vigorous, fruit straight, a little smaller at the ends, bright green, light at the blossom end. Comes into condition for use a little later than the Early Cluster. Price: oz., 10c; 3 ozs., 25c; 1b., \$1.25.
Boston Pickling A distinct and very productive Boston Pickling variety extensively grown for pickles. The fruits are of medium size, very smooth, symmetrical and bright green. Price: oz., 10e; 3 ozs., 25c; 1b., \$1.25.

Improved Long Green (Jersey Pickle). Fruits crisp. The small fruits are used for pickles and larger ones are excellent for slicing. The vines make a strong growth and are very productive. Price: 0z., 15c; 3 ozs., 35̃e; 1b., \$1.50.

Klondike Cucumber This variety is one of the is rich, dark green, and the fruits grow to a uniform size, measuring about 7 inches in length and 2 inches thick when in good condition to use. Price: oz., 10c; 3 ozs., 25c; 1b., \$1.25.

\section{LETTUCE}

Culture. Lettuce, to be at its best, should be grown rapidly, hence the soil should be made as rich and friable as possible by liberal manuring and thorough preparation. For winter, sow under glass from November to February and thin out as necessary. For general crop, sow outdoors as early in the spring as the ground can be worked, in drills 18 inches apart, and thin young plants to 4 inches apart in the row. As the plants begin to crowd, thin them out and use as required. In this way a much longer succession of cutting may be had from the same ground.

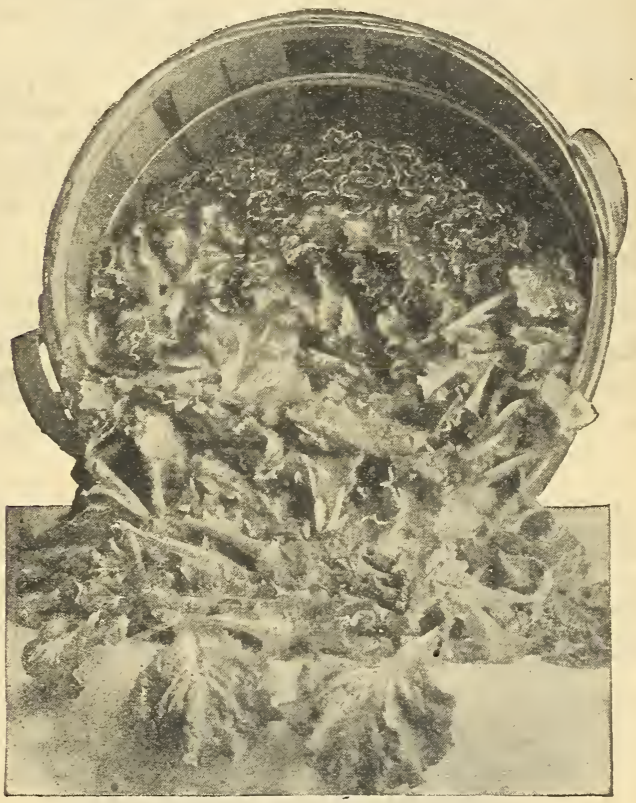

Black Seeded Simpson

Black Seeded Simpson Nearly double the size Black Seeded Simpson of an ordinary Curled Simpson. Stands summer well without becoming tough or running to seed quickly. By far the most popular variety for greenhouse forcing, mak ing large handsome heads in a very short time. Price: oz., 10c; $1 / 4$ 1b., 35c; $1 \mathrm{~b} ., 75 \mathrm{c}$.

Grand Rapids (Seed black). A lettuce for greenhardy, house forcing, quick growth, hardy, little liable to rot and remaining in constand shipping long distances better than most sorts. Price: oz., 10c; 1/4 1b., 35c; 1b., 75c. 
Price per trade packet on seeds described below, except otherwise quoted: 5c each, 6 for $25 c$.

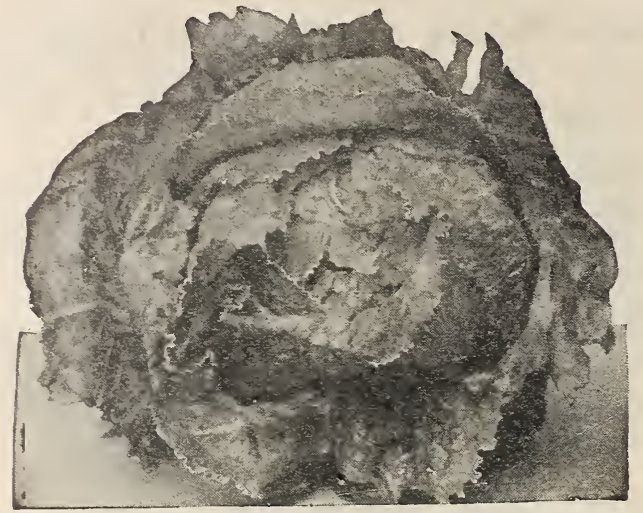

Big Boston

Big Boston. A (Seed White). Popular for large heading sort. Plants large, very hardy and vigorous; leaves broad, comparatively smooth, but wavy at edge, thin, very hard and crisp, color bright light green, the head slightly tinged with reddish brown. Price: oz., 10c; $1 / 4$ lb., 35̃e; lb., 75c.

New York This is one of the finest head letNew York tuce now being grown, extra tender and very brittle. While not as early variety as some it is one of the best for the garden or market. If you are fond of good lettuce don't fail to sow some of this excellent variety.

Price: oz., 10e: $1 / 4$ lb., 35e: 1 b.. $\$ 1.00$.

Early Prize Head. B (Seed White). A large clustering, non-heading lettuce. The most easily grown variety in cultiration. The leaves of the variety are crimped, bright green tinged with brownish red, very tender and sweet. Price: oz., 10c; 1/2 1b., 40c; 1b., 75e.

Early Curled Simpson White seeded. One of tuces. Quite similar to Early Curled Silesia. Price: $1 / 2$ 1b., 40c; 1 b., 75c.

Hanson Leaves are curly and tender and form Slow to a head as large as an early cabbage. $1 / 2$ lb., 40c; 1b., 75c.

\section{MUSKMELON SEED}

Culture. Plant seeds in hills 4 to 6 feet apart each way, after danger of frost is over. Use well rotted manure in the hills. One ounce of seed to 50 hills: 2 to 3 pounds to the acre. A light warm soil is best. In hoeing, draw the soil well up to the plants. Fight bugs with tobacco dust and slug shot.

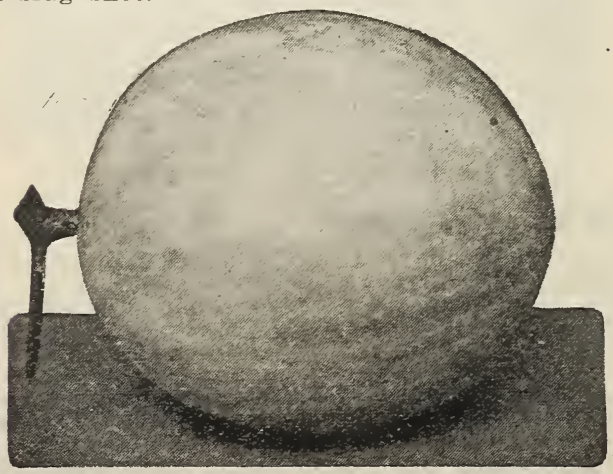

Honey Dew
Honey Dew The skin is a very delicate yelsmooth. The rind is thin, the flesh is very thick and in color blends from a near white at the rind to the daintiest of emerald green at the seed cavity. The flesh is crisp and delicious, very sweet, juicy and possesses a honey flavor, very pleasing to the palate. Price: $1 / 2$ oz., 10c; oz., 15 c.

"Hoodoo" Melon (Introducer's Strain). A new finest quality. Very vigorous, remarkably blight resisting and very productive. Fruits small and of uniform size. Netting exceptionally fine and dense. Flesh very thick. Price: oz., 15c; 1/4 $1 \mathrm{~b} ., 75 \mathrm{c} ; 1 \mathrm{b.}, \$ 2.50$.

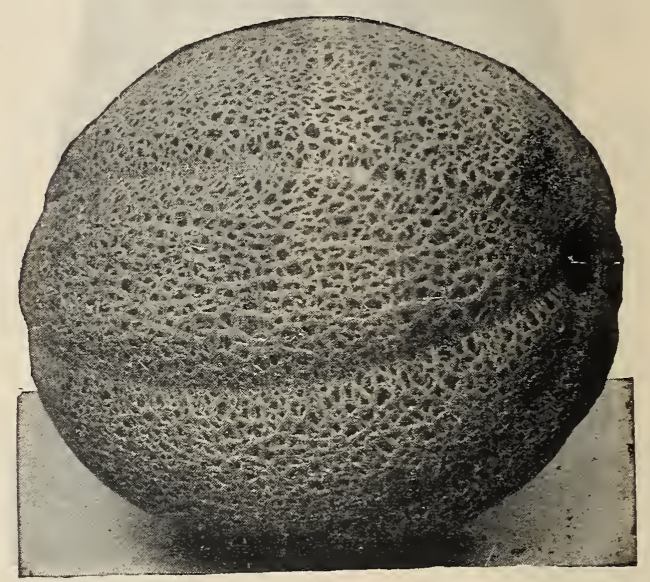

Rocky Ford

Rocky Ford (Netted Gem). The flesh is deep and thick, and light green in color. The flavor is exceedingly fine. The skin is regularly ribbed and thickly netted. It is a heavy cropper, and in wide favor as a market melon. Our seeds are saved from a field in which only seed melons are grown. Very dependable. Price: oz., 10c; 1/2 lb., 75e; 1b., \$1.25.

Emerald Gem One of the sweetest melons in cultivation; smooth skin, deep ideal home melon. Price: oz., 15c; 1/2 lb., 60e; 1b., \$1.00.

Extra Early Hackensack Ten days earlier than Flesh light green and excellent in flavor. Price: oz., 15c; 1/2 1b., \$1.00; 1b., \$1.50.

Hackensack or Turk's Cap The very largest sorts. The fruits are sound, flattened at the ends and have very broad ribs. Flesh is green, fine quality. Price: oz., 10c; 1/2 1b., 60c; 1b., \$1.00.

Osage (Salmon and Green). Medium to large sized, oval, slightly ribbed, dark green in color. Flesh is deep salmon color and very ting. Price: oz., 10c; 1/2 1b., 75c; lb., \$1.25.

Early Citron Landreth's Very early half flat of fair quality. Price: oz., 10c; $1 / 2$ lb., 60c; lb., $\$ 1.00$.

Banana Cucumber shape. Delicious odor. 1/2 lb., 60c; lb., \$1.00. 


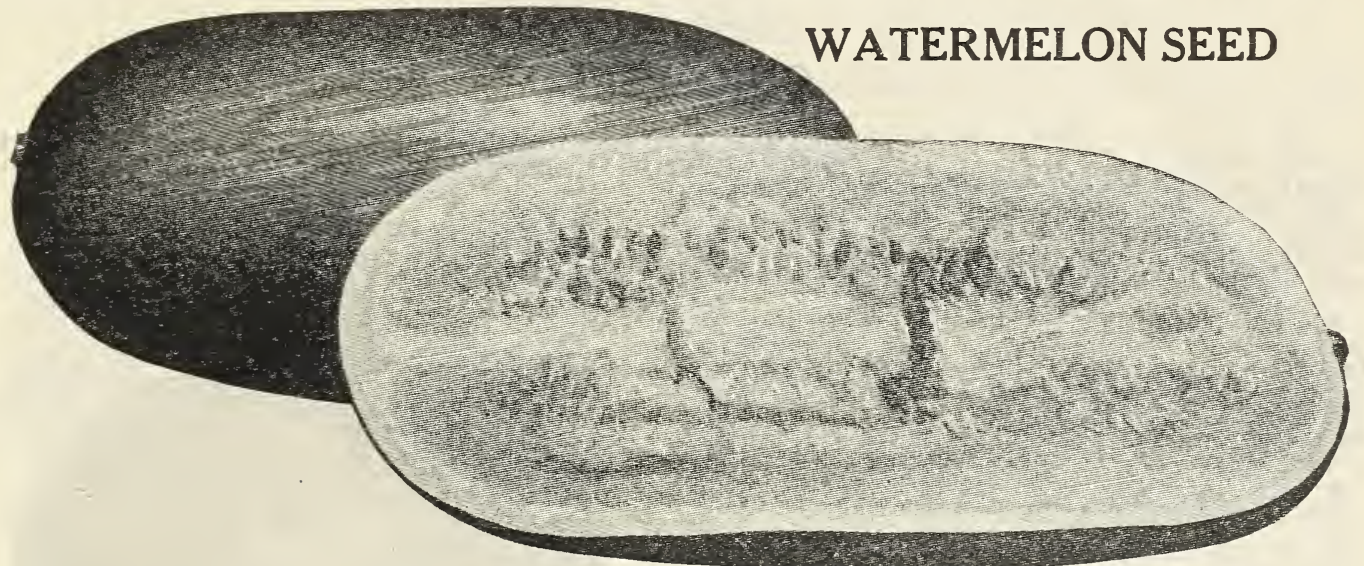

MeIvor's Wonderful Sugar

Culture. The essential thing in melon culture is to get good strong vines early in the season. To this end plant your melons in hills 8 feet apart, made rich with some good fertilizer or well-rotted manure thoroughly mixed with the soil. As soon as the ground is warm and dry plant 15 to 20 seeds in each hill, and thin out when the plants begin to grow, leaving only 3 to 5 of the most vigorous. Protect the young plants from insects and hasten their growth by the use of liquid manure. From 3 to 5 pounds plant an acre. Fight bugs with slug shot and tobacco dust.

One ounce will plant 50 hills and four pounds will plant one acre.

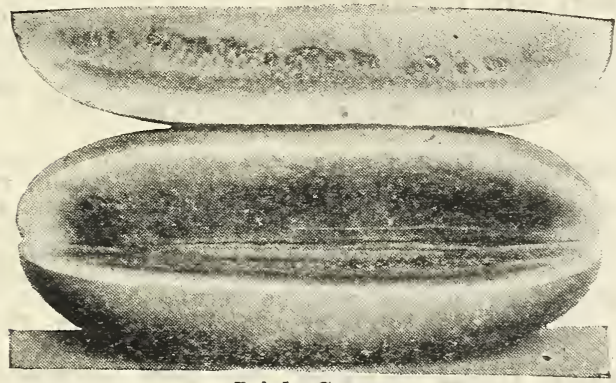

Irish Gray

Irish Gray The old ones go and the new ones Irish Gray come-sometimes the same old girl with a new dress, and then again something grander than ever appeared before-as for instance the Honey Dew in Muskmelons, we now have the IRISH GRAY in Watermelons. A superb new sort just out. Bright, sparkling red flesh, sweet, firm, with a yellowish gray rind. For the home it's better and sweeter than Kleckley's Sweet; has a tough rind; better than Tom IVatson and outyields either of those a half more. It's the thing to catch the market with. Price: oz., 15c; $1 / 4$ ib., 50e; 1b., \$1.25.

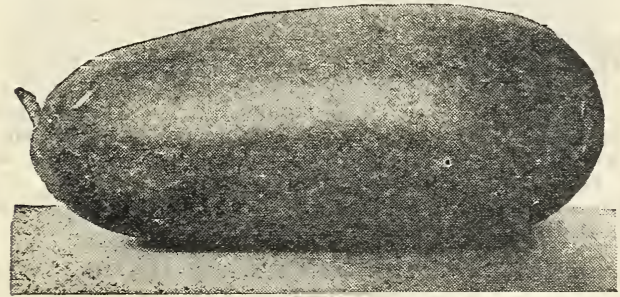

Monte Christo
Monte Christo or Kleckley's Sweets Unsurfor home use or near markets. Melons of medium size, oblong, tapering slightly towards the stem end; dark green. Flesh rery bright rich red, exceedingly sweet. Price: oz., 10c; 1/2 lb., 50c; lb., 90c.

Mclvor's Wonderful Sugar (90 days). This most famous melon for sweetness and high quality. The melons are long, averaging about 35 lbs. each. Rather light colored, irregularly striped and mottled with dark green. The rind is thin, but tough, so that it is a good shipper. Flesh is delicate, light red, entirely stringless, very tender, juicy and luscious. Price: oz., 15c; $1 / 4$ lb., 35c; $1 b ., \$ 1.00$, postpaid.

Cole's Early The earliest watermelon in cultiern states. Black seed, rich red flesh. Price: oz. $10 \mathrm{c} ; 1 / 2$ 1b., 40c; 1b., 75c.

Georgia Rattlesnake Oblong, dark and striped; Peerless or Ice Cream Very early; red flesh; Dark Icing Early, round, solid, with thin dark Dark lcing green skin; of superior quality. Light Icing Round in form like above; flesh Sweet Heart Nottled light green; large, oval, Sweet Heart heavy; red flesh; fine shipper.

Cuban Queen Early, solid and heary; skin Kolb Gem Very large; flesh red; a good shipKolb Gem ping sort; popular in the South.

Green Citron (Red seed), Round and handsome; for preserving only.

Above varieties not priced we quote as follows: Price: oz., 10c; $1 / 2$ lb., 40c; $1 \mathrm{~b} ., 75 \mathrm{c}$; in 5-1b. lots and over, 10c per 1b. may be deducted.

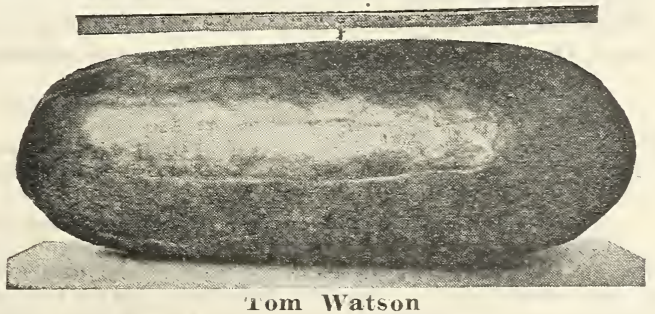

Tom Watson A large. oblong melon, the skin rind is thin but which is dark green. tractive red color, crisp, sweet and delicious. Price: 0z., 10c; $1 / 2$ 1b., 50c; 1b., 80c. 
Price per trade packet on seeds described below, except otherwise quoted: 5c each, 6 for $25 c$.

\section{ONION SEED}

The onion not only contains considerable nutriment and has valuable medicinal properties, but is most useful in counteracting the bad effects of sedentary life. The odor it imparts to the breath may be avoided by thorough cooking.

In onion culture, thorough preparation of the ground, careful sowing and the best of after culture, though essential, avail nothing unless seed of the best quality be used.

Sow the seed as soon as the ground can be gotten ready, and it can be done best with a Planet Jr. hand seed drill adjusted to sow the desired quantity of seed about one-half inch deep. The quantity needed will vary with the soil, the seed used and the kind of onions desired. Thin seeding gives much larger onions than thick seeding. Four to five pounds per acre is the usual quantity needed to grow large onions.

Gathering. As soon as the tops die and fall the bulbs should be gathered into windrows. Cut off the tops when perfectly dry; leave lay a few days.

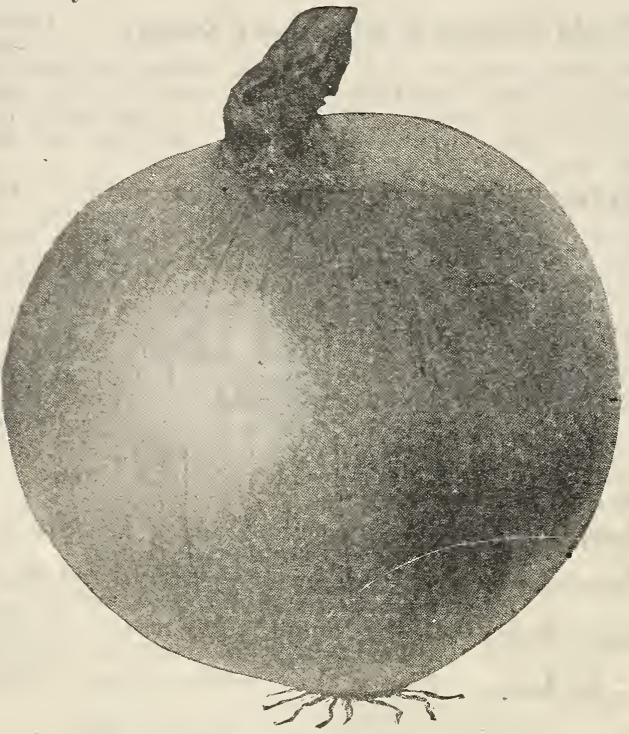

White Globe

White Globe This is the largest successful pure White onion in cultivation. Perfect globe shaped, very solid; keeps well and always brings the top of the market. Price: $1 / 2$ oz., 10c; 1 oz., 20c; 1/2 lb., \$1.25; 1b., \$2.25.

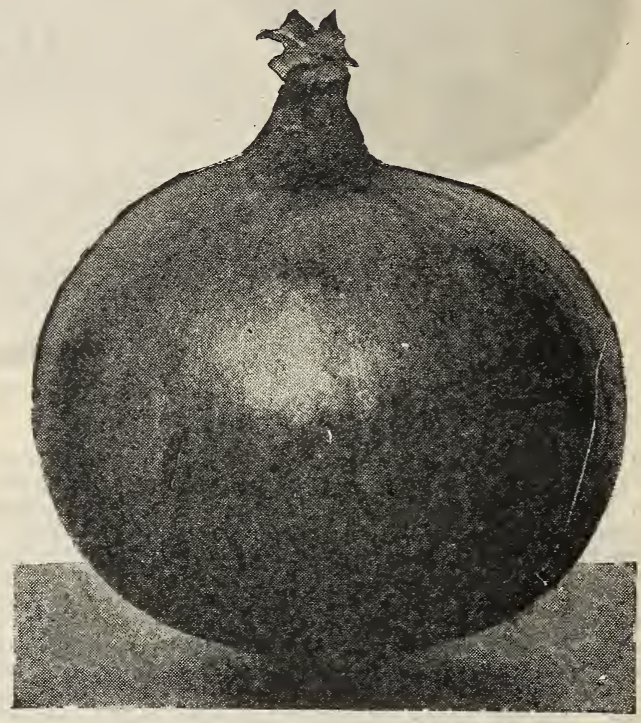

Red Wethersfield

Large Red Wethersfield The best known of all the onions. Good seller, great keeper, the best of all standard sorts. My stock of this onion seed is most select and sure to grow. Price: $1 / 2$ oz., 10c; oz., 15c; $1 / 2$ lb., 60c; lb., $\$ 1.00 ; 10$ lbs., $\$ 9.00$.

Southport Red Globe On account of its beautiful shape and rich red color, these onions bring a premium in any market and is an excellent keeper. The seed we offer is grown from true type bulbs. Subject to test before planting and if not absolutely satisfactory, money will be refunded. Price: $1 / 2$ oz., 10c; oz., 15c; 1/2 1b., 60c; 1b., \$1.00; 10 lbs., $\$ 9.50$.

Yellow Globe Danvers The most extensively Yellow Globe Danvers used yellow onions. Bulbs of medium size, uniformly globe shaped, with small neck and ripen very evenly. Flesh white, crisp and of mild and excellent flavor. Price: 1/2 oz., 10c; oz., 15c; 1/2 lb., 75c; lb., \$1.25.

\section{ONIONS-}

Prize taker (the largest onion grown, very mild)

White Silver Skin, round, white, medium

Mammoth Silver Skin, a large, white onion

New Queen, early, small white onion for pickling

\begin{tabular}{|c|c|}
\hline $\begin{array}{l}1 / 2 \quad 0 z \\
\$ 0.10\end{array}$ & $\begin{array}{l}1 \text { oz. } \\
\$ 0.15\end{array}$ \\
\hline .10 & .15 \\
\hline .10 & .15 \\
\hline .10 & .15 \\
\hline
\end{tabular}

\section{ONION SETS}

Many prefer to grow onions from sets, as they are less trouble and are ready for use earlier than those grown from seed. Sets grown from seed are known as bottom sets. One quart will plant a row 50 feet long. Ten bushels will plant one acre. Multipliers are fine for bunching green. Wo sell by the pound only. Special prices in large lots on all varieties. Bottom onion Sets, per 1b., 15c; 3 lbs., 40c. Perennial Sets, 15c lb., 3 lbs., 35c. Summer Top Sets, 25c lb. Multiplier or Potato Sets, 20c per 1b. Add 6e per 1b., 2 lbs., 8c; 5 lbs., 11c, if by parcel post.

NOTICE-ALL PRICES SUBJECT TO MARKET CHANGES AND STOCKS ON HAND. WhEN out of any one kind. we reserve the right to fill with next best at price of next best. 
Price per trade packet on seeds described below, except otherwise quoted: $5 \mathrm{c}$ each, 6 for $25 c$.

\section{RADISH SEED}

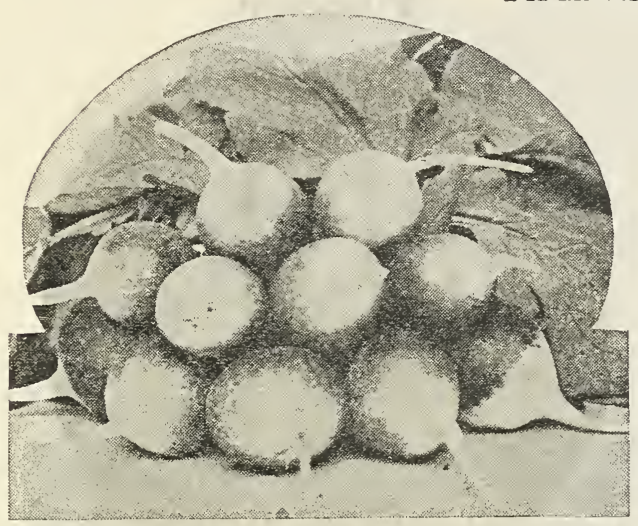

Culture. For forcing under glass, scatter evenly over the surface 100 seeds to the square foot and cover with one-half inch of soil, sifted. For open ground culture, sow on rich, sandy soil as soon in the spring as it is fit to work, in drills twelve inches apart and thin out the plants if necessary to prevent crowding. A good dressing of nitrate of soda will greatly stimulate growth and insure tender and brittle roots. Successional sowing from one week to ten days apart will keep up a supply. After the hot weather of summer begins it is better to sow the summer and winter varieties, as they do not become tough and stringy nor pithy as the earlier sorts are apt to do when planted in late summer time. One ounce sows about 50 feet of row.

Remember, a succession is secured by planting seed every ten days.

Saxa Globe Radish This is the best forcing Saxa Globe Radish and quickest outdoor radish to date. A new 20 -day variety. Remarkable for the small size of its leaves. The flesh is firm, crisp and fine quality, dark red, globe shaved bulbs of even size. Price: $1 / 2$ oz., 10c; oz., 15c; $1 / 416 ., 50 c$.

Icicle The finest eating, a most Distinctive cicle Long White Radish... The best eating radish, and the best white variety. This sort has long, slender, pure white roots, which remain mild and crisp until they grow of larger size. Tops are quite short, making it early, and also allowing close planting. A succession is secured by planting seed every ten days. Price: pkt., $5 c$; oz., 10c; 1/2 lb., 60c; lb., $\$ 1.00$.

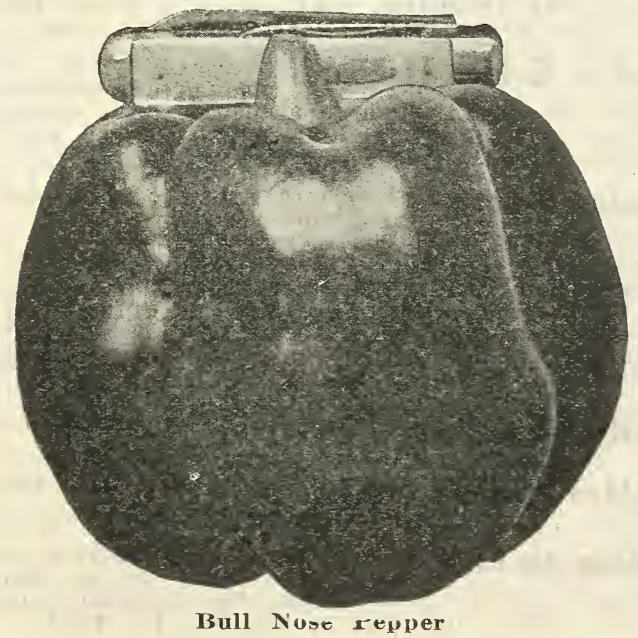

SPECIAL PRICES 5 TO 10 LB. LOTS ON ALL SORTS.

Scarlet Turnip, White Tipped One of the the turnip radishes and a great favorite in many large markets for early outdoor planting. Roots slightly flattened on the under side, color very deep scarlet with a white tip; flesh white and of the best quality. Price: oz., 10c; 1/2 lb., 50c; lb., $\$ 1.00$.

Early Scarlet Turnip A splendid extra early, Price: oz., 10c; 1/2 1b., 50c; 1b., 80c. Plant every ten days.

Early Scarlet Globe A desirable sort for hotEarly Scarlet Globe bed forcing and outdoor planting... Very early; top small. One of the best selling and most attractive radishes on account of its bright scarlet color and handsome shape; flesh white and tender, fit to pull in 28 days. Price: oz., 10c; 1/2 1b., 75c; 1 lb., $\$ 1.40 ; 5$ lbs., $\$ 6.00$.

Crimson Giant An early sort, looking much Globe, but more perfect in shape. It comes early b-it keeps on growing and remains tender, solid and sweet until it gets as large as a teacup or larger. Price: oz., 10c; 1/2 1b., 75c; lb., \$1.25.

\section{Radishes}

French Breakfast, stump rooted

1 oz. $1 / 2$ lb. $1 b$.

French Breakfast, stump rooted $\$ 0.10 \$ 0.60 \$ 1.00$ Long Scarlet Short Top ……........ Chartier Half Long White,

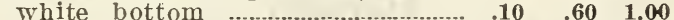

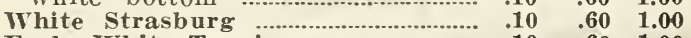

Early White Turnip .................................

\section{Winter Sorts}

Cal Mam White Winter Rose White Winter ............................. .10 .601 .00 Black Spanisl, round or long......

Manure Ash Fertilizer Analyzes 2 per cent phomonia, 8 per cent hosphoric acid and 2 per cent potash, and is manufactured solely with animal and vegetable matter. It is recommended upon actual knowledge of results for home gardens, radishes, truck gardens, potatoes, and most field crops. Price: 4 lbs., 25e; 15 lbs., 50c; 100 lbs., \$3.50.

\section{PEPPER}

(One ounce will produce about 1,800 plants). Sow seed in hotbed early in spring; transplant to open ground when the weather is farorable. Seeds germinate slowly and require considerable heat. Chinese Giant Most gigantic of all Giant Pepper, of enormous size, magnificent appearance and brilliant, glossy scarlet color. The flesh is mild and unusually thick. Price: $1 / 2$ oz., 25c; oz., 50c; 1/4 1b., \$2.00.

Large Bell, or Bull Nose An early standard Red Cayenne Pods long and slim, of medium $1 / 1$ 1b., 75̃e.

Ruby King Very large size. When ripe they color. Price: oz., 25c; $1 / 4$ lb., $\$ 1.00$. 


\section{Spinach}

An easily grown plant; the seed may be planted in the fall to secure good spinach early in the spring or even throughout the winter. The better and richer the soil, the larger and more tender the leares will be. Use 8 pounds of seed per acre. For the home garden use one-half ounce for 100 feet of row.

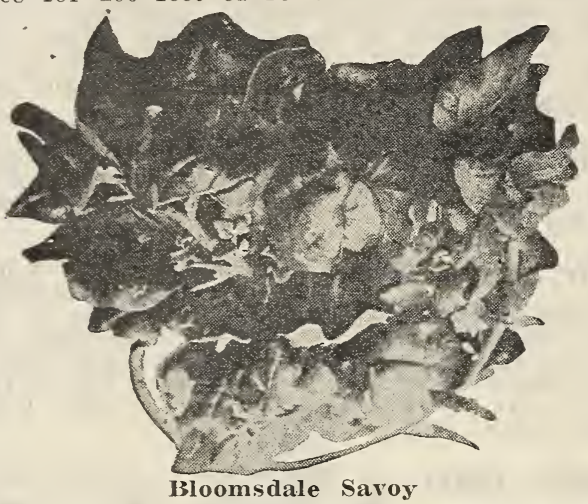

Long Standing A deep green variety with rathSeed, round. Stands a long time without running to seed. Price: oz., 10c; 1b., 60c.

Bloomsdale Savoy The variety most generalround and thick. Very much savoyed and rich dark green. One of the earliest rarieties. Price: oz., 10c: 1 lb., 75c.

\section{Parsnip}

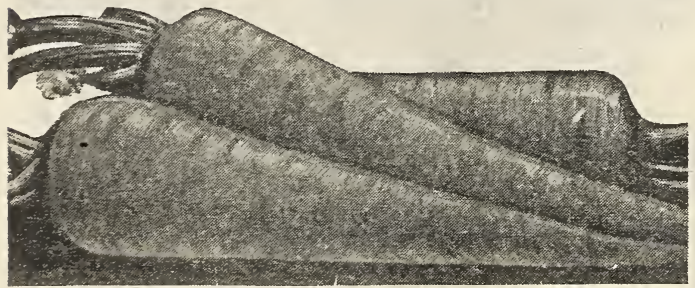

(One ounce will sow 200 feet of drill).

Sow early in spring in good, rich soil, which has been plowed deep. They are improved by frost.

Improved Hollow Crown Fine grained and $10 c ; 1 / 4$ lb., 30c; 1b., ซ5c.

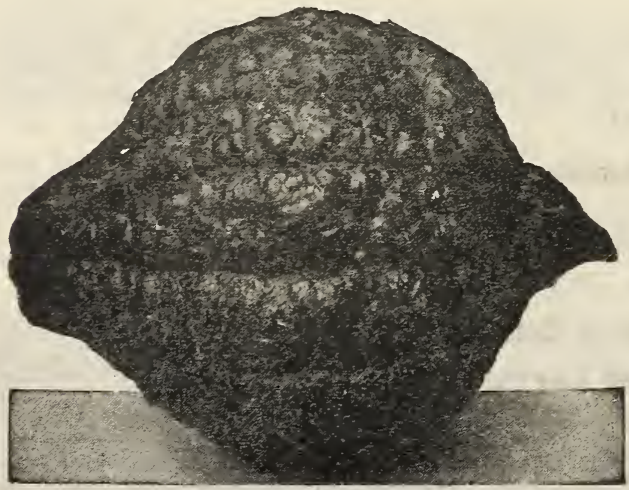

Hubbard Squash, True Warty

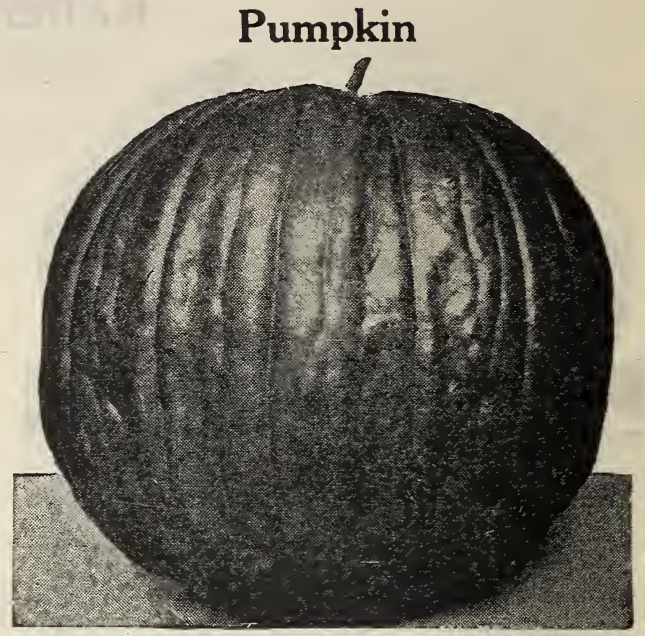

Sugar Pie Pumpkin

Culture. Plant from May to July in hills 6 feet apart each way. One ounce for 15 hills: two pounds to an acre.

Connecticut Field or Cow Pumpkin The big kind that is grown so much in the corn fields. Price: oz., 10c; 1 lb., 75c: 4 lbs., \$2.50.

Small Sugar Best of all Pie Pumpkins. very a Tankee Pumpkin but smaller. Early and prolific. Price: oz., 10c; $1 / 4$ lb., 35c; lb., $\$ 1.25$.

Quaker Pie A very prolific variety; a good pies. Price: oz., 10c; $1 / 4$ 1b., $40 \mathrm{c} ; 1 \mathrm{~b} ., \$ 1.50$.

Green Striped Cushaw Fruits rery large, with creamy white, irregularly striped or traced with green. Flesh light yellow, very thick, rather coarse, but sweet. This sort is very productive and popular in some sections. Price: pkt., 5c oz., 15̃c; 2 oz., $25 \mathrm{c}$.

\section{Squash}

True Warty Hubbard The standard winter shaped, with dark green skin and very rich flesh. Almost everyone is well acquainted with the Warty Hubbard. Our strain is extra tine and very warty. Price: $1 / 4$ lb., $30 \mathrm{c} ; 1 \mathrm{b.}, \$ 1.00$.

Red or Golden Hubbard A perfect type of the green hubbard except in color, which is a bright, deep orange yellow, very showy and attractive. Flesh deep, golden yellow. Price: oz., 15c.

Boston Marrow This is a very productive fall and winter variety of medium to large size, oval shape, and thin skin. It is much used for canning and making pies. The fruits when ripe are bright orange with a shading of light cream color. The flesh is of rich salmon yellow color, finely grained and of excellent flavor, but not as dry as the Hubbard. Price: pkt., 5e; oz., 15c; 1/4 lb., 40c.

Early White Bush Price: oz., 15c.

Golden Summer Crookneck Price: oz., 15 c. Mammoth Chili A very large and attractive raorange yellow, flesh thick, fine grained and sweet. Price: oz., 15c; $1 / 4$ lb., 50c; 1b., \$1.25. 
Price per trade packet on seeds described below, except otherwise quoted: 5e each, 6 for 25 .

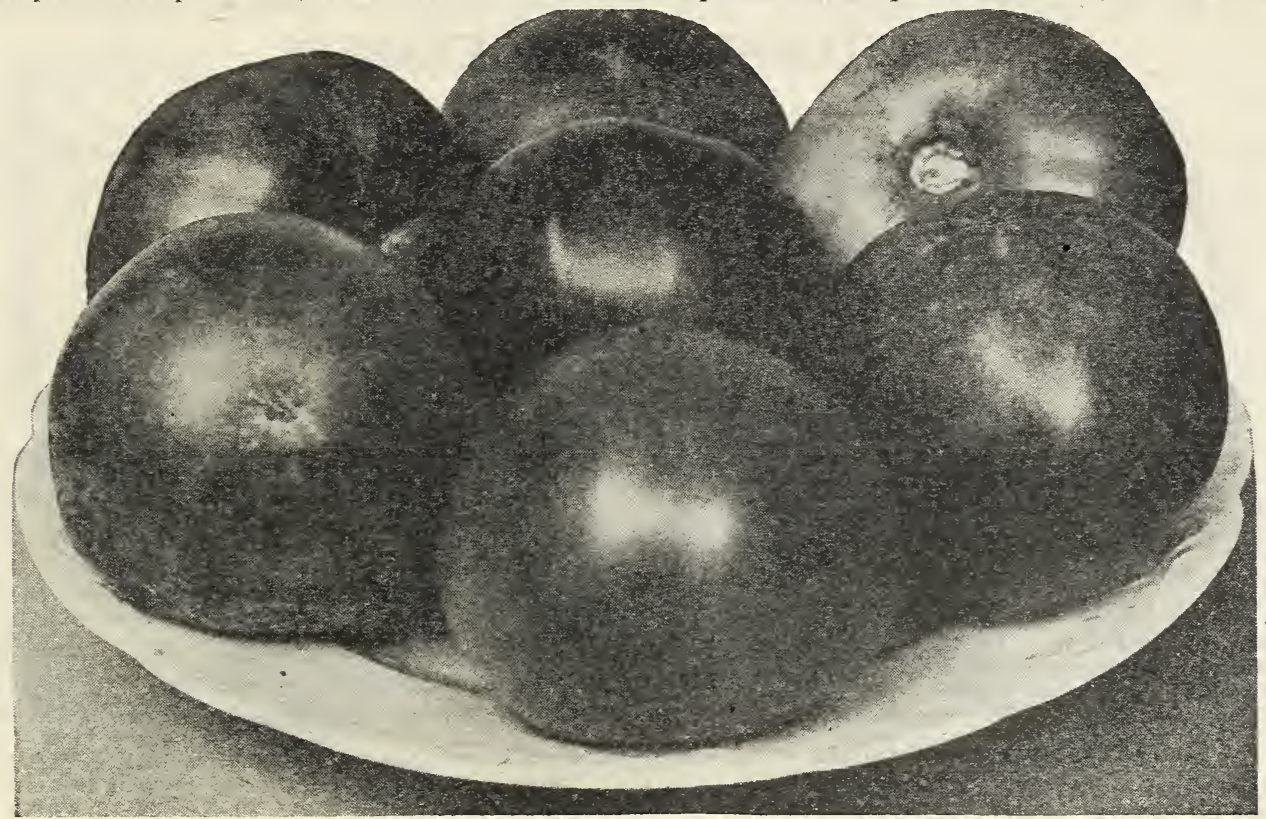

bonny Best

\section{SPECIALLY SAVED TOMATO SEEDS}

We do not use canning factory seed. One ounce produces about 2,000 plants. For early crop sow in hotbeds in January or February. For late crop, in open beds in May.

Culture. Sow in a hotbed in early spring or the seed may be sown in shallow boxes and placed in a window when one does not wish to have the trouble of making a hotbed. Transplant to the open ground when all danger of frost is past, setting the plants three or four feet apart each way. Use Bone and Yotash Fertilizer, or well rotted manure in the hills.

Bonny Best The fruits of this desirable early and color. The crop ripens more uniformly than any other early scarlet fruited sort, and is of superior solidity and interior color. The vines are vigorous and produce a good crop of exceptionally round and deep fruits. One of the best for gardeners whose trade demands fruits of beautiful shape and color. Price: $1 / 2$ oz., 20c; oz., 35c; $1 / 4$ 1b., \$1.25.

Dwarf Champion A purple fruited variety bushy plant two feet high. Often sold as Tree Tomato, Fruit smooth, medium sized, fairly solid and of good flavor. Desirable for forcing, as it can be planted more closely on the bench than the tall growing kinds. Price: 1/2 oz., 15e; oz., 25e; 1/4 1b., \$1.00.

Ponderosa The largest variety in cultivation. Price: $1 / 2$ oz., 20c; $1 / 4$ lb., 75e.
Earliana It is a full week ahead of all others. Plants of strong growth and very productive; fruit large, deep red, and of superior quality. Smooth and free from cracks. Price: 1/2 0z., 10c; oz., 20c; 1/4 lb., 75c.

Early Acme One of the earliest and handsomest varieties. Medium size, perfectly smooth and regular, very solid fruit, borne profusely. Dark red with purplish tint. Price: 1/2 oz., 10c; oz., 20c; 1/4 1b., 60c.

New Stone One of the heaviest and most solid Vines vigorous and productive farge tomatoes. slightly flattened, very large, very rich scarlet. Price: 1/2 oz., 10c; oz., 15c; $1 / 4$ 1b., 50c; 1b., \$1.50. Dwarf Stone Plants grow dwarf and stocky, like those of Dwarf Champion, out close together. The fruit is like Stone, solid and deep red, and of fine quality. Ripens a little earlier than Stone. It is worth planting in every home garden. Price: 1/2 oz., 15̌c; oz., 25e; 1/4 1b., \$1.00.

Golden Queen A very handsome yellow tomato of large size. Price: 1/2 Yellow Pear and Yellow Plum A small yelis grown fol preserves. Price: 1/2 oz., 15e; oz., 25̌c.

Other Varieties We can supply any of the here or not.

For Tomato Plants see page 29.

\section{TURNIPS}

Early Turnips should be planted very early. Late Turnips can be sown in July or August and will keep growing until the ground freezes. Use 2 pounds of seeds to an acre.

Extra Early White Milan The earliest turnip. very erect and compact. Price: oz., 15c; $1 / 2 \mathrm{lb}$., $60 \mathrm{c} ; 1 \mathrm{b.}, \$ 1.00$.

Extra Early Purple Top Milan Similar to the except the upper portion is a beautiful purplered. Price: oz., 15c; $1 / 2$ 1b., 60c; 1b., \$1.00.

Purple Top, Strap-Leaved The most popular grown than any other turnip; will form good size bulbs in seven or eight weeks. Price: oz., 10c; $1 / 2$ lb., 40c; 1b., 60c.
Purple Top White Globe of a perfect shape skin. Flesh pure white, firm and crisp and of quick growth. Price: oz., 10c; 1/2 1b., 40c; 1b., 60c.

\section{Rutabaga or Swedes}

Improved American Purple Top For the fine productiveness this is the best. The roots are finer and larger than the ordinary; the flesh is a rich yellow. Price oz., 10e; $1 / 2$ lb., 40c; lb., 65̃e. 
Price per trade packet on seeds described below, except otherwise quoted: 5c each, 6 for 25̃.

\section{MISCELLANEOUS VEGETABLES}

\section{Asparagus}

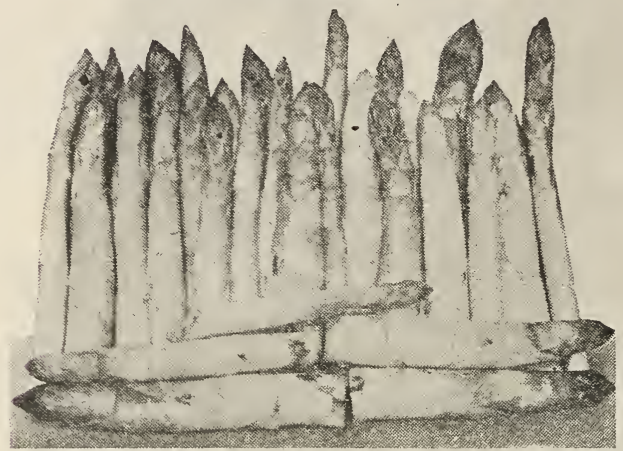

The Asparagus bed furnishes the first green delicacy for the table in the spring, is universally popular and requires but little care.

Bonvallet's Giant. Price: oz., 15c.

Columbia Mammoth White. Price: oz., 10c.

Conover's Colossal. Price: oz., 10c.

Asparagus Roots. Two years old. See page 29.

\section{Cress or Pepper Grass}

Early Curled. Well-known salad. Sow at intervals all season. Price: oz., 20c.

True Water. Sow seeds along the border of running water. Price: $1 / 2$ oz., 20c.

\section{Egg Plant}

A tender plant that should be started quite early in a hotbed and transplanted.

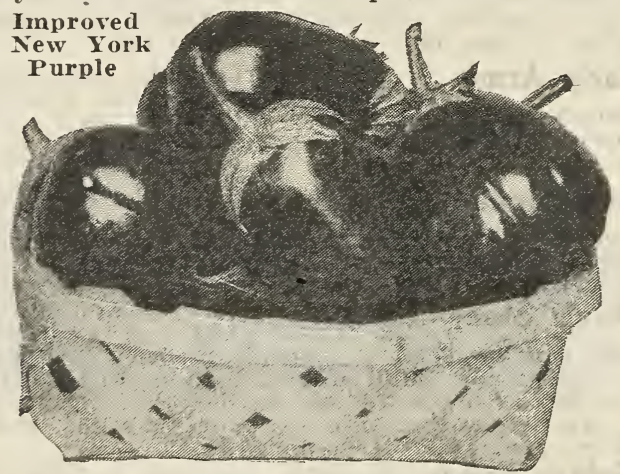

New York Improved Large Purple. Fruits large, nearly round, dark purple, free of thorns. Price: 1/2 oz., 30c; oz., 50c.

Black Beauty. Fruit large, symmetrical in shape and of a rich dark purple color. Little earlier than our Improved Large Purple. Price: $1 / 2$ oz., 30c; oz., 50c.

\section{Endive}

(One ounce will sow about 60 square feet).

One of the best salads for fall and winter use. Sow seed in April for early use or in June or July for winter use. When leaves are eight inches long tie them together with a string near top to blanch. Price: oz., 15c.

\section{Broccoli}

The culture is the same in all essentials as for cauliflower. Withstands greater extremes of temperature than cauliflower

Early White Vienna... Extremely early, with distinctly small tops. Price: $1 / 2$ oz., 15c.

1 iarly Purple Vienna. Very early, with small top, the left stems being tinged with purple. Price: $1 / 2$ oz., 15c.

\section{Mustard}

New White Chinese. Leaves tender and delicious. Price: oz., 10c.

\section{Kohl Rabi}

The Kohl Rabi is a vegetable intermediate between the cabbage and turnip and somewhat resembles each in flavor. The edible part is a turnip shaped bush formed by the enlargement of the stem. Price: $1 / 2$ oz., 15c.

\section{Brussels Sprouts}

Improved Half Dwarf. The plants grow two to three feet high and produce from the sides of the stalk numerous little sprouts which resemble small cabbages one or two inches in diam. eter. Price: 1/2 oz., 25c.

\section{Kale or Borecole}

Dwarf German. Very hardy, with dark green leaves; much improved by frost. Price: oz. 15c.

Dwarf Curled Scotch. Dwarf, beautifully curled, bright green. Price: oz., 15c.

\section{Leek}

Belongs to the onion family. Set the roots deep and draw the earth to them when cultivating.

London Flag. The variety generally cultivated in this country. Price: oz., 20c.

\section{Parsley}

(One ounce will sow 150 feet of drill).

Sow very early, thinly in drills one foot apart and half an inch deep. Soak seed in warm water a few hours before sowing.

Champion Moss Curled. A rery select stock finely crimped and curled. Price: oz., 10c; $1 / 4$ lb., 25c; 1b., 75̃c.

Hamburg. Turnip-rooted variety; used for flavoring soups.

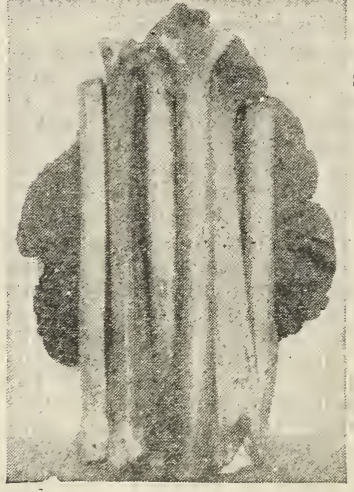

Large Victoria Rhubarb

\section{Rhubarb} seed.

Easily raised from

Large Victoria. The s t a ll d a r d variety. Price: oz., 10c; $1 / 4$ lb. 30c; lb., 85e; postpaid.

For Rhubarb Roots see page 29.

\section{Salsify}

Mammoth Sandwich Island. By far the largest and best for market. Roots of superior quality and double the size of the old variety. Price: oz., 25c.

\section{Sweet Herbs}

Anise Seeds, aromatic

$1 / 2$ oz. $\$ 0.10$

Caraway (Cat Mint)

Coriander, for flavoring

Dill (2 oz., 30c; $1 / 4$ 1b., 50c)

Lavender

Marjoram, Sweet

Saffron

Sage, Broad Leaf

Savory, Sumner

Thyme

\section{Mushroom Spawn}

Mushroom Culture. Mushrooms may be grown any place where the conditions of temperature and moisture are favorable. A shed, cellar, cave or vacant space in greenhouse. Twelve page painphlet telling how to prepare bed, plant and grow the crop, 25c each, free with order for $\$ 1.00$ worth of spawn.

We carry the American Spawn Co.'s Pure Mushroom Spawn, conceded to be the best spawn sold. Always fresh.

American Spawn, in bricks, each ........................\$0.30 One brick, by mail, postpaid .40 
Price per trade packet on seeds described below, except otherwise quoted: 5c éach, 6 for $25 c$.

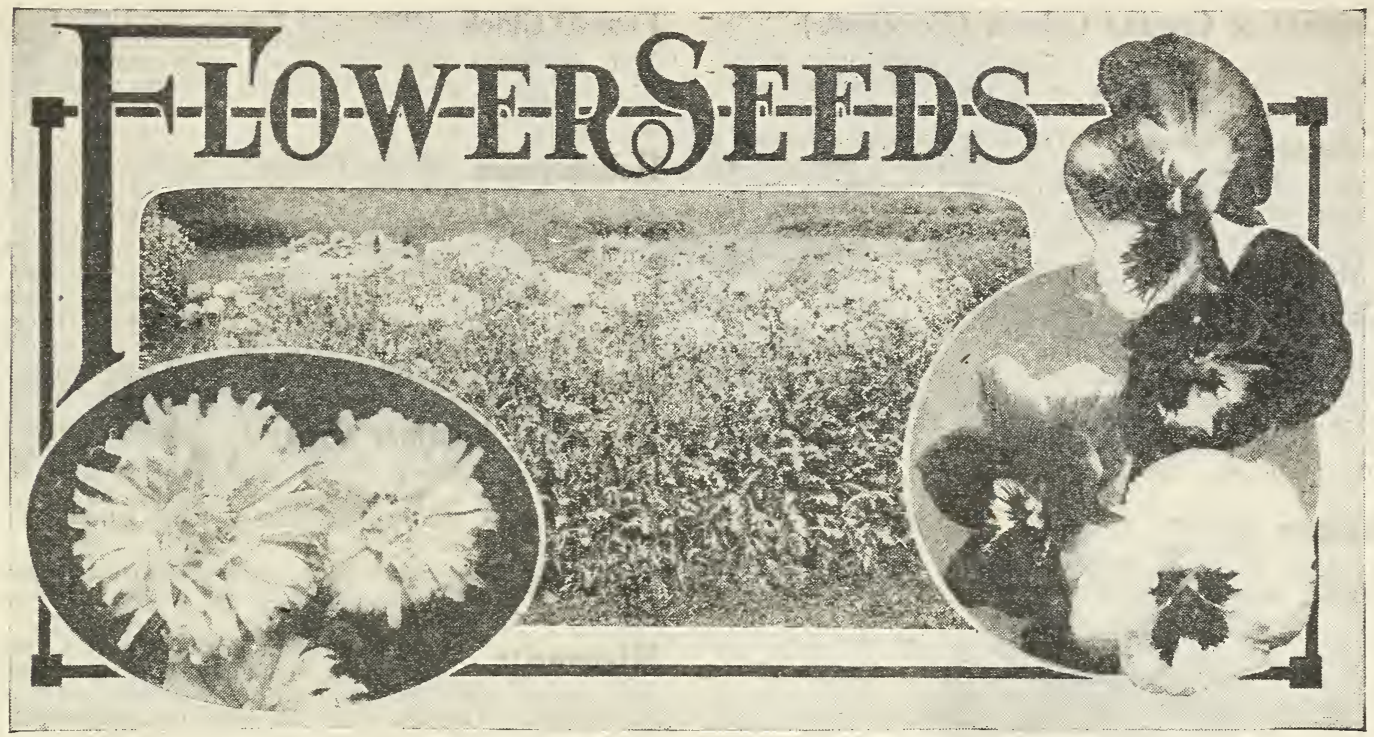

\section{BULK FLOWER SEEDS}

Are better, cost less, more certain to grow than paper seeds.

One of the most cherished recollections that we have of our mother's or grandmother's home is that of the beautiful array of brilliantly colored flowers-marigolds, daisies, pansies, balsams, asters, pinks, poppies, nasturtiums and other flowers in great array.

\section{NOTICE!}

Prices: All Flower Seeds in Bulk put up in quantities of 10c, 15c and 25c worth of each sort to suit buyer. In ordering items not priced in this list state value of each kind wanted and we will fill accordingly. Trade packet, 5c each; 6 for $25 \mathrm{c}$.

Alyssum Sweet scented, hardy annual, blooms early in the spring; a pure white Alyssum Procumbens (Carpet of Snow). This sweet scented annual, It grows 2 inches high with the appearance of a flat pancake. The mass of blooms completely hide the foliage giving the appearance of a corering of snow. Pkt., 5c; 1-8 oz., 15c.

\section{Asters}

Asters. In their many varieties and colors, are the grandest and most beautiful flowers that bloom in the home garden.

American Beauty This new type of Aster of the most attractive of all large flowering branching sorts, vigorous grower and profuse bloomer with whorled center as the flower unfolds. Comes in three shades:

$$
\text { American Rose (September Beauty) }
$$

American Pink American Purple Trade Pkt., 15c; 1-16 oz., 25c; 1-8 oz., 40c.

Extra Early Express or Early Wonder These the earliest blooming Asters, commencing to bloom with us in Julv. Flowers large and full, of the Comet type. Finest mixed. Trade pkt., $15 \mathrm{c} ; 1-8$ oz., 25c.

Michael's Giant Branching Plants 21/2. to 3 ing and robust habit. Flower large and double, throwing no single flowers. Our selected stocks of these are the best money can buy. Mixed. Pkt., 10c; 1-16 oz., 15c; 1-8 oz.; 25c.

Sensation Bushy and branching plant about incurred, resembling a Dahlia and the flower a lively cardinal red. This is the rery best of the red Asters. Pkt., 10c; 1-16 oz., 15c; 1-8 oz., \&5̃c. Calliopsis Snowy border plant, flowers bright colored or with these colors and red contrasted. All sorts mixed.

Candytuft Showy, branching plants six to July to September, or if planted in the fall from May to July. All sorts mixed.

Castor Bean (Ricinus). Tall, majestic plants mer lawns, with leaves of green very quick growth in rich soil. Zanzibariensis, very large green; and the Gibsonia, beautiful bronze foliage. Pkt., 5c; 1/2 oz., 15c.

Calendula (Officianalis). This variety has and form the finest Aster. It blooms profusely with a succession of bright deep orange flowers from July until frost.

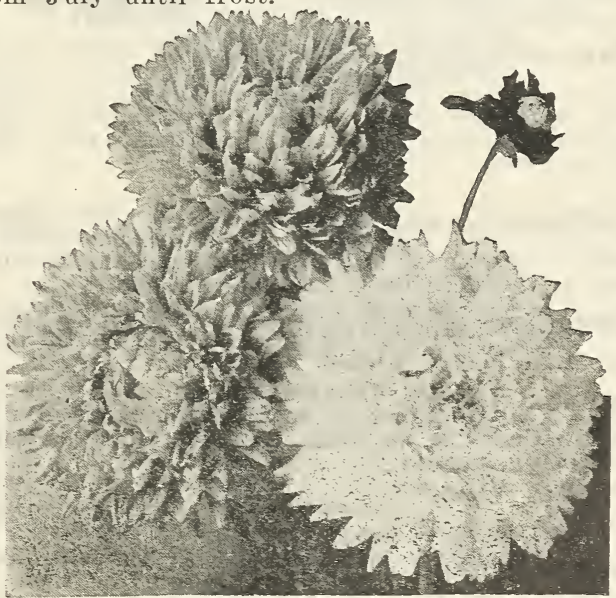

American Beauty Aster 
Cristata or Crested Celosia (Coxcomb) Verylar annuals of easy culture, producing large, ornamental, comb-like heads like ruffled chenille. Prized for pots or summer flower beds.

Celosia (Plumosis). Distinct variety bearing a profusion of beautiful ball-shaped wooly flower heads of intense scarlet. Sometimes called the Wool Flower. Surpassing the Red Geranium in blooming effect and blooms all summer until frost comes. Price: Pkt., 10c; 1-16 oz., 25c; 1-8 oz., 40c.

Celosia. Plumosa Cristata A plumed cockses large plumes of many colors which are as delicate and fluffy as the finest ostrich feathers and are wonderfully beautiful. Cockscombs of various shapes with a texture like relvet plush, the most brilliant and lasting annual. Pkt., 10c; 1-16 oz., 25c.

Balsam Known as Lady 'Slipper and TouchBalsam Me-Not. The colors range from white to dark purple. Hardy Annual, one to two feet high. Mixed Double Sorts.

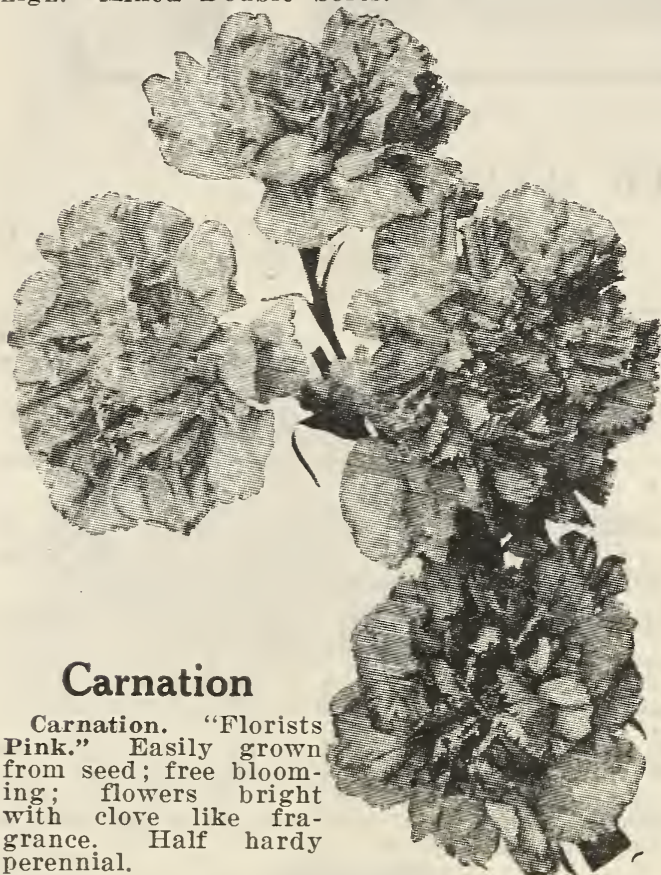

Margaret These are deservedly the most popular Carnations with the amateur. This strain is extra fine quality, producing an abundance of large, double, beautifully-fringed, highly scented flowers. All colors mixed, pkt., 10c; 1-8 oz., 20c.

Centuria-Cyanus (Bachelor Buttons, Corn Flowone of the most attractive of garden flowers. One to two feet high. Double mixed.

Coreopsis Very showy, free flowering plants, ders and beds. Yellow Flowering.

Cosmos A rery effective autumn flower, bushCosmos like plants 3 to 5 feet high, and covered with large, single, dahlia-like flowers. Early Flowering, mixed.

Cypress Vine A most beautiful climber with delicate, dark green, feathery foliage, scarlet blossoms. Tender, annual.

Forget-Me-Not (Myosotis). A farorite oldprofusion fashioned flower, bearing in well in the. shade or open border. Hardy perennial.
Four-0'Clock (Marvel of Peru). The flowers are four funnel-shaped and open about four 0 clock in the afternoon and remain open all night and generally perish before noon next day; will grow in any soil. Hardy annual, "2 feet high.

Helichrysum (Straw Flower). A great demand Helichrysum for this everlasting flower has induced us to list it. It is an ornament to the garden and is everywhere prized for winter decorations in vases as permanent boquets. The flotrers intended for drying should be gathered when partially in flower and suspended. with heads down in a cool place. Pkt., 10c; 1-16 oz., 15c; 1-8 oz., 25c.

Heliotrope Highly valued for the fragrance of their flowers and duration of bloom.

Kochia or Summer Cypress (Kochia Tricopornamental annual, having a cypress-like appearance. Its bright autumn coloring has given it two other names: "Mexican Fire Plant" and "Burning Bush."

Marigold Old-fashioned flower blooming in protill frost comes.

Mignonette A well-known hardy annual, proMignonette ducing exceedingly fragrant flowers. Seed sown in autumn will bloom early in the spring; thrives best in cool temperature; 1 foot high. Mixed Sorts and New Machet.

Morning Glory Handsome, showy climber, suitable for covering windows, vines. Hardy annual. 10 feet high. Giant Japanese Mixed,

Pinks For beautiful and lasting cut flowers, ease of culture and freedom of bloom, annuals: 18 inches high Chinese Double, fine mixed; Midnight Blood Red, Double White.

\section{Petunias}

For freedom of bloom, variety of color and effectiveness these have no equals. If only a little care is bestowed upon them. Petunias will produce their handsome. sweet-scented flowers in their delicate and gorgeous colors throughout the whole summer.

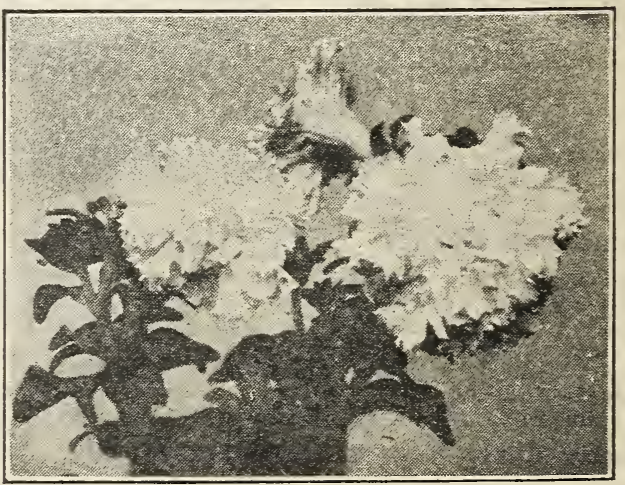

Michael's Double Fringed

Michael's Superb Double Fringed Sared from unrivaled collection: will produce a large percentage of double flowers of the largest fringed varieties in bright colors. Per 100 seeds, 25c.

Howard's Star.A beautiful, free flowering with a clearly defined five-opointed star of blushwhite. For bedding, baskets, rases, etc., this is exceptionally fine. Pkt., 10c; 1-16 oz., 25c.

Rosy Morn Soft carmine-pink with white at the same time effective border. 1-8 oz., 75c. 
Price per trade packet on seeds described below, except otherwise quoted: $5 c$ each, 6 for $25 c$.

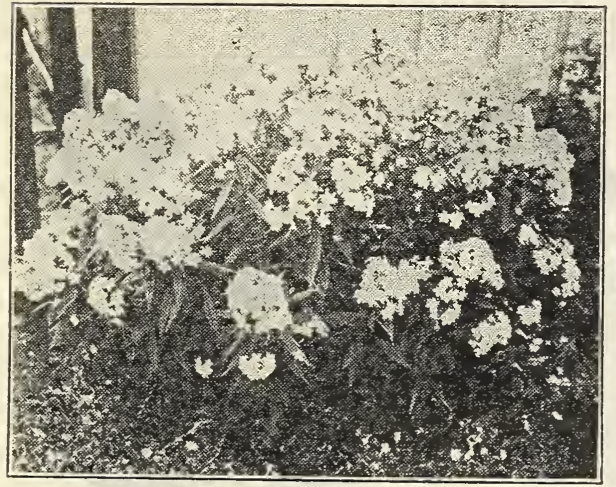

Phlox Drummondi

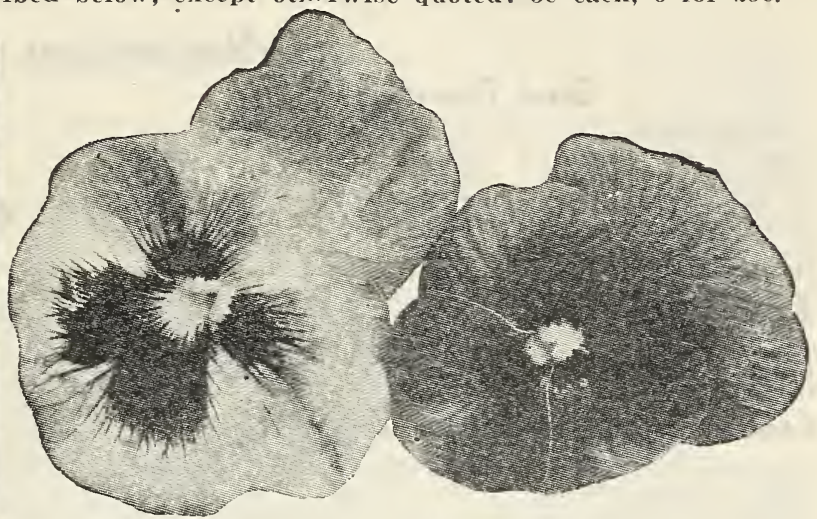

Pansy
Phlox (Drummondi). The Phlox is the earPhlox liest and hardiest of all the annuals. it occupies a most prominent place in the flower garden and produces a rariety of flowers of beautiful colors, which is varied with stripes, reins and points of contrasting shades. Fine Mixed. Pkt., 10c; 1-16 oz., 15e; 1-8 oz., 25e.

Poppies Great advance has been made in rePoppy. No other flower produces a more brilliant display of colors during the blooming period. Single Mixed: Pkt., 5c: 1-16 oz., 10c.

Double Mixed: Pkt., 5e; 1-16 oz., 15c.

American Legion (New Poppy from Flanders) This new single Shirley is a dazzling orange scarlet of enormous size, borne on long, stout stems. The plants are of very erect robust growth. Pkt., 10e; 1-16 oz., 15e; 1-8 oz., 25c.

Portulaca or Rose Moss There are a few flowthat ers in cultivation The flowers close in shadow but are open in sunshine. Single Mixed: Pkt., 5c; 1-16 oz., 15c; 1-8 oz., 25c. Double Mixed: pkt., 15e; 1-16 oz., $25 \mathrm{c} ; 1-8$ oz., 40c.

Salvia Among the most brilliant colored flowSalvia ers and extremely useful for bedding. Blooms are of fiery red crimson color, continuing to flower for a long time. Tender perennial; blooms until frost; height 2 to 3 feet. See page 19 for plants. Salvia Splendens: pkt., 10e; 1-16 oz., 25c; 1-8 oz., 40c.

Salpiglossis. Very showy bedding or border plants, with richly colored, funflowers, which are purple, scarlet, crimson, yellow, buff, blue and almost black; height, 1 foot. Fine Mixed Sorts.

Stocks To such perfection has selection brought this flower that good seed will have a large proportion of exceedingly double flowers. Average height, $1 \frac{1 / 2}{2}$ feet. Double Mixed, pkt., 10c; 1-16 oz., 25̃c.

Sweet Williams For displav in the garden, the Sweet Williams Sweet William is unsurpassed. The seed can be planted in the spring in the open ground and will blossom in the fall. Hardy perennial; $11 / 2$ feet high. Fine mixed single. Mixed Double.

Verbena Sown in May, they will bloom in in pots in should be soaked in luke warm water before planting and care should be taken that the soil be very rich. Half hardy perennial trailer; 6 to 10 inches high. Fine Mixed Hybrida Giganta: pkt., 10c; 1-16 oz., 25c; 1-8 oz., 40c.

Lucifer (New) Brilliant scarlet, no eye, an im25e; $1-8$ oz., 40 c.

\section{Pansies}

Pansies. Pansies are now produced in almost infinite variety of form, color and markings. We have the plants as well as the seed. See page - for plants. Giant Flowering, 1-16 oz., 15c; 1-8 oz., 25e. Choice mixed, many colors. 1-16 oz., 15e; 1-8 oz., 25c.

Masterpiece (New Giant Curled or Spencer Pancurled so the flowers appear double.

\section{Zinnia}

Showy plants with large, double flowers. Might be taken for dwarf dahlias. Few flowers are more easily grown or bloom more abundantly throughout the season.

Double Giant A special strain of this grand duces flowers of colossal size, specimens measuring from 5 to 6 inches across. Mixed colors: pkt., 10c; 1-16 oz., 15c; 1-8 oz., 25e.

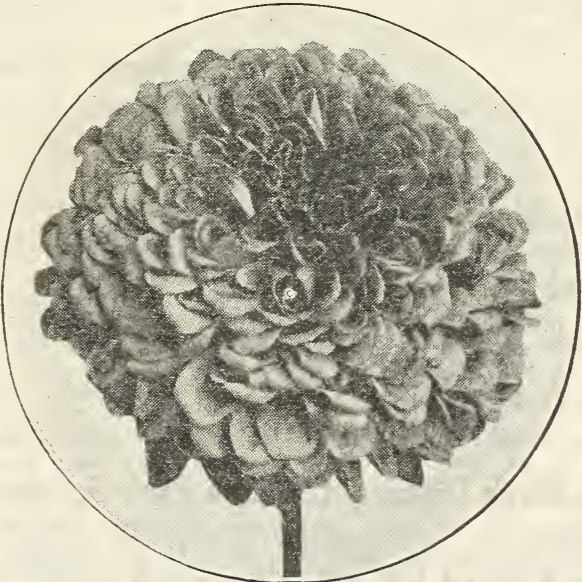

Dahlia Flowered Zinnia (New). Similar in in our illustration above. The range of colors not only include the usual shades, but many unusual tones, such as salmon, old rose, cerise, strawberry-red, etc. Pkt., 10c; 1-16 oz., 20c; 1-8 oz., 35c.

Jacqueminot Zinnia This splendid red flowering Zinnia is just covered with velvety, double red flowers through out the summer until frost, with the effect of red roses. Pkt., 5c; 1-8 oz., 15c.

Giant Picotee (New Double Zinnia). A remarkable new and distinct class with of dark, resembling the Picotee Carnations-most attractive and pleasing. All colors mixed. Pkt., 10c; 1-16 oz., 15c; 1-8 oz., 25c. 
Price per trade packet on seeds described below, except otherwise quoted: $5 c$ each, 6 for $25 c$.

\section{Giant Flowering}

Nasturtium. Few flowers equal the Nasturtium in richness and rariety of colors, freedom of bloom and ease of culture. They are suitable for bedding and handsome climbers, grow quickly, thrive in the poorest soil and furnish the greatest abundance of long lasting, sweet-scented cut flowers.

King Theodore (Tall Growing). Rich, deep, King Theodore crimson flower; most striking and beautiful of all tall-growing Nasturtiums. Foliage dark green and vigorous. 1 oz., 15c; 1/4 lb., 40c.

Lobb's Climbing Nasturtiums These should founded with the common tall Nasturtiums, as they surpass them by far in the remarkable brilliancy of the flowers. The flowers are much larger than those of the old-fashioned kind, and in nearly all of them the petals overlap each other. 1/2 oz., 10c; oz., 15̄c.

Tall Chameleon The flowers of this new nasturtium are in color crimson, cold and bronze, bordered and flamed, changing in hue almost daily, hence named "chameleon." $1 / 2$ oz., 10c; oz., 15c.

Tall Mixed (California Giants). In this mixof all colors and varieties. found the choicest 1b., \$1.00.

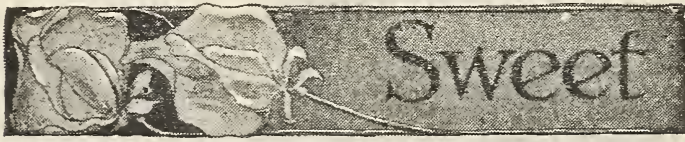

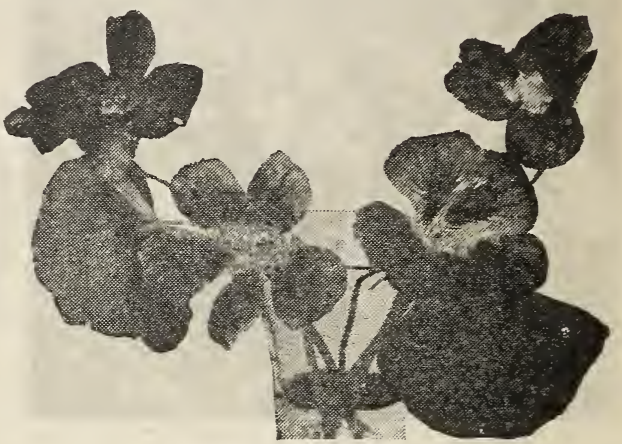

Dwarf Nasturtium

King of Tom Thumb A dwarf variety with iners, dark green foliage. 15c per oz. 1/4 1b., 40c.

Dwarf King Theodore Velrety red flowers iage. Price 10c per oz., 1/4 1b., 40c.

Dwarf (Mixed). A special mixture of Dwarf Nasturtium of a great many colors in even proportions. 10c per oz., 1/4 lb., 25c; 1b., 75c.

Sweet Peas. Sweet Peas are among the most beautiful of all our hardy annuals. Select a sunny, open place several feet from any building and as far as possible from large trees. Sow as early in the spring as possible. Plant in rows and have the rows trenched for planting 4 to 6 inches deep. In dry weather water freely and keep the flowers picked closely. If allowed to go to seed the plants will stop blooming.

\section{Spencer Standards Varieties}

The Spencer Types are exceptionally large size, with long stems, the wings waved or frilled and the effect remarkably graceful and attractive. All Spencers are decidedly shy seeders. The price higher than for the older (Grandiflora) type. We offer in the different shades, what we consider to be the best varieties.

Apple Blossom Spencer (Rose Spencer). Standard with true Spencer form. Per 1/2 oz., 15c; oz., 25c; 1/4 1b., 75c. Blanch Ferry (Pink Spencer) Usually a little darker some of the flowers show striping. It is one of the most attractive varietfes ever introduced. Per $1 / 2$ oz., 15c; oz., $25 \mathrm{c} ; 1 / 4$ lb., 75c.

Etta Dyke (White Spencer) Standard and wings of waved and fluted. An especially attractive variety of very large size. Per 1/2 oz., 15c; oz., 25c; 1/4 1b., 75c. Mrs. Hugh Dickson (Salmon Pink Spencer) on cream background, strong growers; throws four flowers to a stem. Per 1/2 oz., 15c; oz., 25c; 1/4 lb., 75̃.

King Edward VII (Red Spencer) The best pure red Wither; very large $1 / 4$ lb., 60c. Otheilo (Maroon Spencer) of immense size, with rich maroon. Per 1/2 oz. 20c; oz., 35c; 1/4 lb., \$1.25.

Spencer Mixed All the Spencer varieties included in makSpencer Mixed ing up this magnificent mixture. A large size and wonderfully attractive form. Per 1/2 oz., $10 \mathrm{c} ; 0 z ., 15 \mathrm{c} ; 1 / 4$ lb., 50c; 1b., \$2.00.

\section{GRANDIFLORA TYPE}

Eckford Mixture This is an old and well known mixsome of the entire list and cannot fail to give the very highest satisfaction of the Grandiflora Sweet Peas that have for years been the pride of the flower garden. Price: per $1 / 2$ oz., 5c; oz., 10c; $1 / 4$ lb., 25c; 1b., 60c.

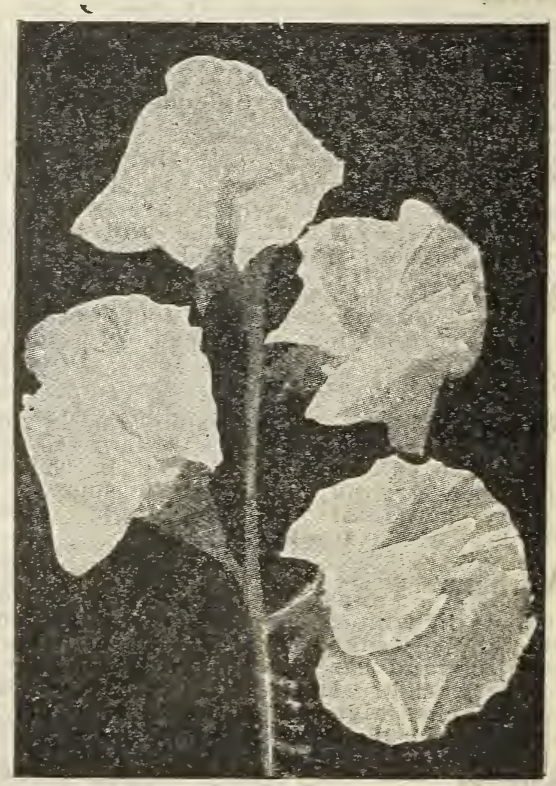

Spencer Type 


\section{ALFALFA AND CLOVER SEED}

\begin{abstract}
Caution. It is fully as incumbent upon the part of the buyer to see that he gets what he bought as it is upon the part of the seller to exercise every caution and care to furnish what he sold. Mistakes occur in the best regulated business. The buyer should therefore check his purchases over, examine it carefully just before planting, and know positively that all is correct.

\section{Alfalfa}

The Clover and Grass Seed we handle are clean and free of all foul and obnoxious weed seed. We invite everyone interested to call and inspect our stocks before buying elsewhere.
\end{abstract}

Remember, all prices we are not quoting on the changes without notice. Grain bags, extra, 60c each.

Turkestan Alfalfa Our seed is imthe cold northern country of Asiastic Turkestan, on the Siberian plains of Russia. Recommended by the U. S. Government Department of Agriculture for years as the hardiest strain of this great forage plant to be found anywhere on Mother Earth. We offer this seed for sale, true and tried, 99 per cent purity, highest germination. Superfine quality, subject to market changes, we quote $\$ 10.00$ per bu.

Native Alfalfa-Non-Irrigated $\begin{gathered}\mathrm{T} h \mathrm{is} \\ \text { clover }\end{gathered}$ frand plant is now a success everywhere. Every farmer has either heard of or knows its worth and merit. The plant grows, thrives and does well on any of the rolling prairies or well-drained bottom lands. The young plants are tender; the seed should not be sown until the frost has left and the ground is warm. One bushel of 60 lbs. will sow three or four acres. It should not be cropped or pastured the first year. Can be planted with a light nurse crop of barley, speltz or wheat.

The stock we handle is northern grown native Nebraska, super-fine quality, which we quote subject market change, per bu., $\$ 10.00$, and Dakota grown seed, superfine quality, per bu., \$12.00.

Grimm Alfalfa A very hardy, acclimated strain Grimm Alfalfa developed in Minnesota. The roots are more or less of lateral tendency, and do not consist entirely of one straight tap root. For this reason it is desirable for land having a hard sub-soil, which is difficult for the roots to penetrate. It is claimed by the Department of Agriculture that it has come to be through its long continued acclimating absolutely one of the hardiest varieties that we have in America. Price on application.

\section{Red, Alsike and White Clover}

Medium Red Clover This by far the most imrieties for practical purposes. Sow in spring or fall, and if no other grasses are used, at the rate of 15 pounds per acre... More is used on old soil than on new. Per bu., $\$ 12.00$.

\section{Mammoth Red or Sapling Clover (Trifolium}

Similar to Red Clover, but coarser, more hardy. Sow from 12 to 15 pounds per acre. Alsike or Swedish Clover The most hardy of rich, moist soil it yields an enormous quancity of hay or pasturage, but its greatest value is for sowing with other clover and grasses, as it forms a thick bottom and oreatly increases the yiela. Sow in spring or fall at the rate of

10 pounds per acr
seed, $\$ 11.00$ per bu.

White Clover A small perennial variety vallawns. It accommodates itself to a variety of soils and can be grown anywhere. Can be used to great advantage in pasture mixtures. Sow in spring at rate of 8 to 10 pounds per acre. Per lb., 60c; price per 100 on application.

\section{Sweet Clover}

There are two preferred varieties, White and Yellow Flowering Biennial Varieties. The White Flowering Biennial is preferred to all others because it grows taller, makes a more powerful root growth and produces more forage. It can be planted very early in the spring-time with or without a nurse crop. Its first year's growth is two to three feet. The first year's crop for hay should be cut in the latter part of the summer or early fall. It can be cut close without injury to the plants. The second year's crop for first cutting should be cut high for hay, not later than the first appearance of the blossom. White Flowering, fancy seed, per bu., $\$ 6.00$. Yellow Flowering, fancy seed, per bu., $\$ 6.00$.

Giant White Annual This is a new type brot Hughes of the Iowa state College. It is just like the big biennial white except that it is annual and makes its entire growth and seeds the first season. Also called Hubam. We quote subject to market changes, $\$ 1.00$ per $1 b$.

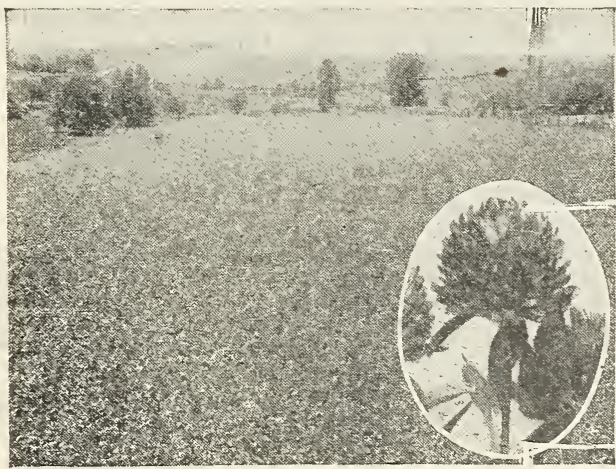

Field of Medium Red Clover

See Page 44 for Nitragin cultures, inoculation for Alfalfa, Sweet Clover and other legumes. 


\section{Timothy}

Timothy. This well-known grass is the best of all grasses for hay. Succeeds very well on all moist land. Should be cut just when the blossom begins to fall. Can be sown in spring or fall. one bushel sows 3 acres. Is used in mixture with clover and other grasses to good advantage. We quote subject to market change, superfine quality, per bushel, $\$ 2.50$.

\section{English Blue Grass}

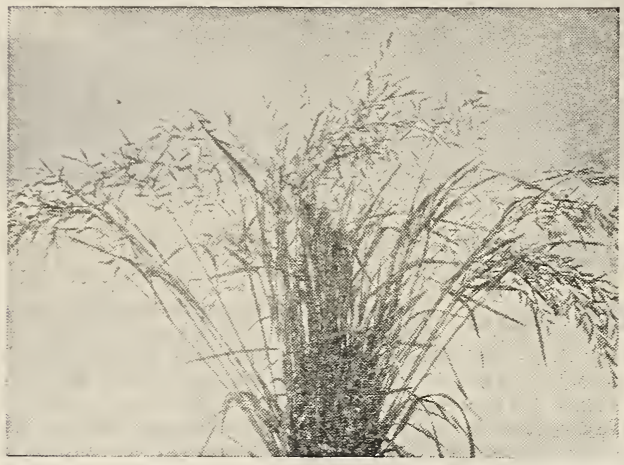

English Blue Grass kinds of soil, but is well adapted to moderately

\section{Kentucky Blue Grass}

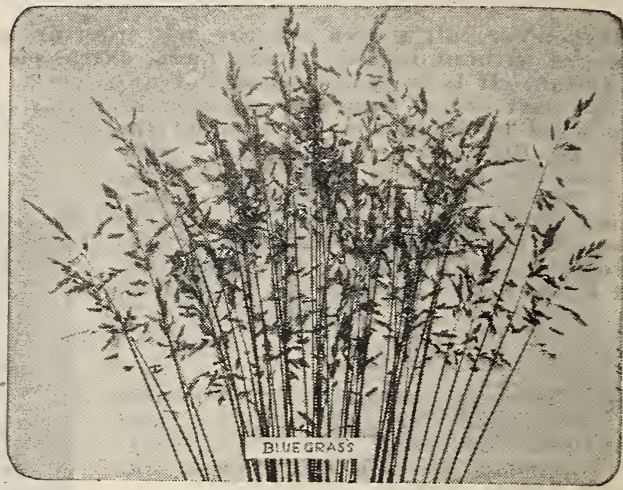

Kentucky Blue Grass

The universal pasture grass of America and the finest lawn grass in the world is our own Kentucky Blue Grass.

It starts like magic with the first smile of spring and is a velvet green until winter comes. It can be grown on the wild prairie and will catch, but the best results are to be had by getting the seed well mixed with the soil. The seed we offer is fresh, clean and pure. Sold at rate of $14 \mathrm{lbs}$. per bushel, which we quote subject to market changes, 21 lb., quality, $\$ 8.00$ per bu... For lawn culture, double weight, our Purity Brand, 100 per cent pure, highest germination, y5e per $1 \mathrm{~b}$.

\section{Red Top}

It is a success everywhere, on all kinds of land and never freezes out. It comes early in the spring, is green all summer and lasts until late autumn. It's an early quick crop and a nutritious pasture grass. It's a perennial, 2 to 3 feet high, and heads out in June. Best seed, per 1b., 35̃c. About 15 Ibs. per acre. $\$ 25.00$ per 100 lbs.

\section{Bromus Inermis}

\section{(Awnless Brome Grass)}

A hardy perennial standing extremes of heat, cold and drouth better than any other of our cultivated grasses. It is especially adapted to the Northwest. It grows with great rapidity and produces luxuriant pastures. The aulysis made shows that it is exceedingly rich in fleshforming ingredients. Sow about 15 to 20 pounds to the acre. Per lb., 25c. Choice Dakota grown seed, per bu. of 14 lbs., \$2.75.

\section{Orchard Grass}

Orchard Grass, This grass does well everywhere, and for hay can be cut much earlier than timothy. Succeeds the best of grasses in timbered lands or orchards. Sow one to two bushels per acre. Per 1b., 30c; bu., of 14 lbs., \$3.00.
Red Top. This

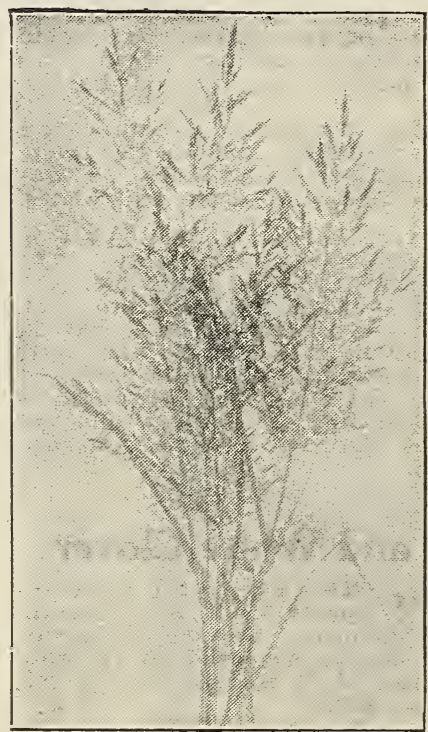

Red Top grass is especially suited to low, we t, s pout y lands; is in fact, the only grass which is a real success on such soil. St and $\mathrm{s}$ our northern winters, can be sown on wet l aind without cultivation, and will catch. Into the wet soil it spreads its network of roots, tames the land, and in a few y e a $\mathrm{r}$ s makes a d e e p, substantial sod. The seed of te $n$ comes in the chaff, but the only thing to $p$ lan $t$ is the solid seed, clea $n$ from chaff. Sow 10 pound s per acre. We quote best solid seed, rery best, per lb., 35c; per 100 lbs., \$22.50.

\section{Rye Grass}

This grass, though but an annual in this climate, in a very short time after the seed is sown it makes as fine pasture as other grasses of long standing. The leaves are very dark green with a rich tint to the blade. It makes a pasture quick as oats or rye would, and being a grass is of far greater value. It makes a splendid winter pasture if left to cure on the ground. Per lb., 25c; per 100 lbs., \$12.50. 


\section{FORAGE AND FIELD SEEDS DEPARTMENT}

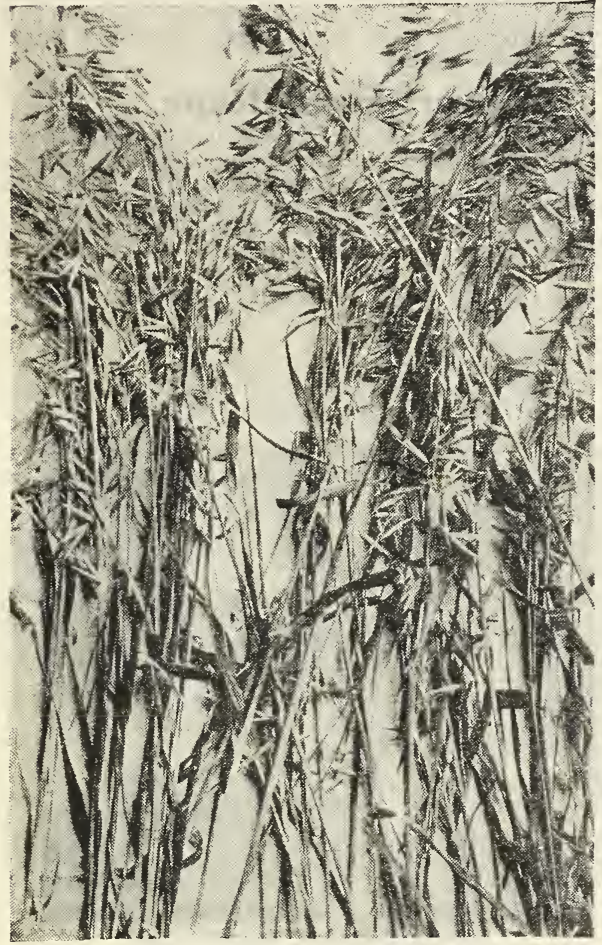

\section{Seed Oats}

Iowa No. 103 Seed Oats. This is a very probred lific new variety of white oats, in a plant of that variety on the Iowa Agricultural College ground at Ames. Attention to this sport developed what is known as the Pedigree Iowa No. 103 Oats. It is an immense cropper, great yielder. outyielding the parent stock by almost double. Has a good, strong stock and stands well under adverse conditions. Every farmer interested in these crops should get at least enough to get his seed stock started from this valuable sort. Price: Per bu., \$1.00. Special price on quantity.

Pedigree Oats No. 105 This is a yellow oat bred Iowa Agricultural College, who recommended it with unstinted praise as the best yellow oat ever introduced. J. O. Westrum, of Hamilton County, writing, says: "It is an early rariety with strong. stiff straw that stands well on rich, black soil or slough land, is a great yielder and beats anything in oats ever raised around here." $\$ 1.00$ per bu. Special price in quantity.

Fancy Oats. Under this heading we offer standto get from our customers who make a specialty of oats. These oats are carefully recleaned and are able to offer at a very reasonable price and make special prices in quantity.

\section{Sugar Cane for Fodder}

The greatest of all forage and fodder plants. It will yield two crops of fodder and a good fall pasture in one season. Roots deep into the subsoil and stands the drouths that often destroy other crops. As a rough provender it is unsurpassed. Sow 1 to 2 bushels per acre. Subject to market change, \$1.25 per bu., bags extra, 35c. Special prices in quantity on application.

\section{Tennessee Millet}

Pure Tennessee Millet of all the well-known kinds, by far the most valuable. This well known sort aches the acme of perfection in the more southern tates, and it is a fact that when the southern aller stalk, and heavier growth of foliage than can ossibly be raised from our own northern grown Plant three-fourths bushel per acre. Price: n application.

\section{Sudan Grass}

Vhat U. S. Department of Agriculture thinks bout Sudan Grass. That it is a tall annual grass, rowing when sown broadcast, to height of 4 to 6 eet. It stools abundantly, as many as 100 stalks ming from a single root. Yields two cuttings in nemi-arid sections of the West. Drilling or broadasting 15 to 25 pounds of seed per acre. Lb., 10c; 00 lbs. for $\$ 5.00$. Price in quantity on application.

\section{Speltz}

Has now been grown in the United States in a way for several years and each succeeding at only emphasizes its value, but sees its roduction increasing to an enormous extent.

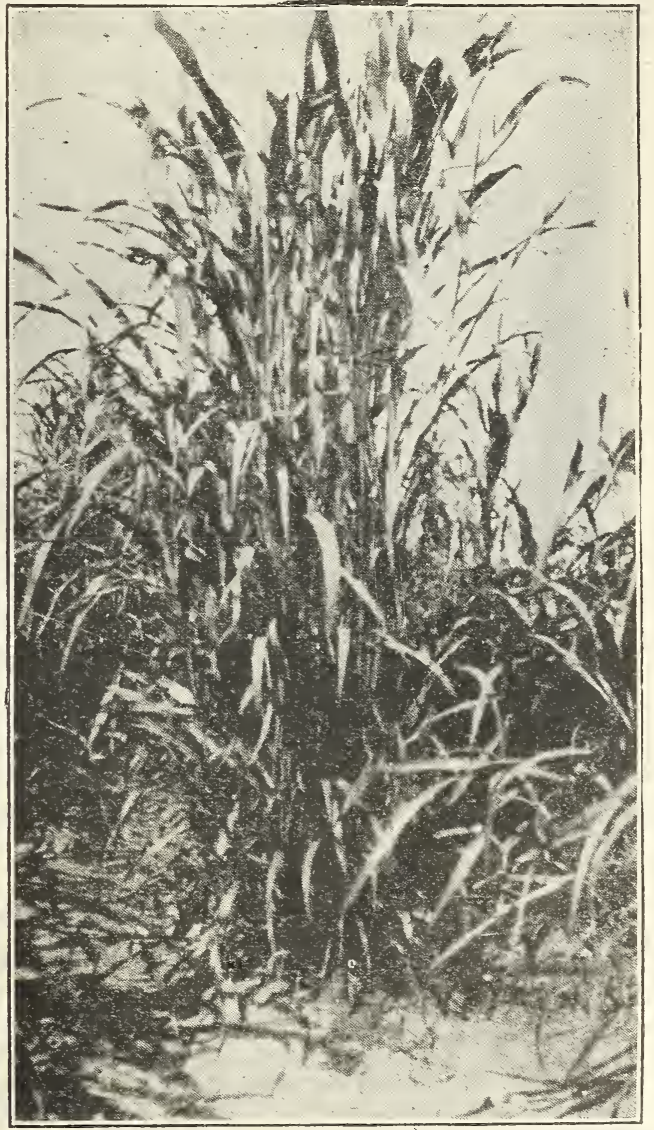

Sudan Grass 


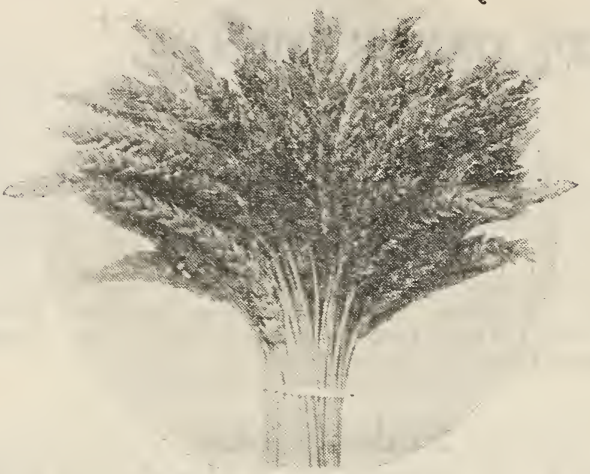

\section{Marquis Wheat}

A Thousand Dollar Prize Wheat of Canadian Origin

Unquestionably the best all-around spring wheat grown. Has yielded as high as 50 bushels to the acre. Extremely early and productire as well as hardy. A favorite in Minnesota and is the best beardless wheat for Iowa farmers. Grows stiff, strong straw and is two weeks earlier than Blue Stem. Easy to handle at harvest, for it is free from beards. Millers praise it highly. Price on application.

\section{Winter Rye}

ROSEN RYE. This is a variety of recent introduction by the Michigan Agricultural College. It is a stiff-strawed, hardy, white winter variety of wide adaptation. It is developed from Russian parentage. Has large, white kernels, yielding in abundance. $\$ 1.50$ per bu., bags extra.

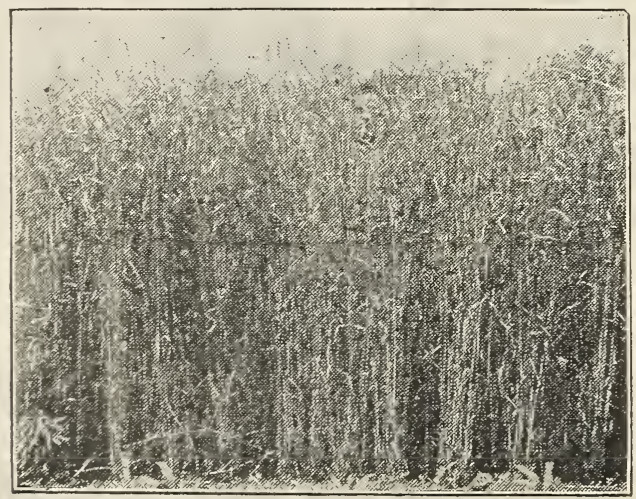

Field Rosen Rye

\section{Feterita}

A Variety of Kaffir Corn, the New Drouth Resisting Plant

Feterita was introduced recently and has al ready in one year made a great name for itself in the drouth stricken southwest country. It is 25 days earlier than Kaffir Corn, outyield Kaffir by far and is little affected by drouth. Per bu., \$1.50. Regular White or Red Kaffir Corn at $\$ 1.25$ per bu.

\section{Buckwheat}

This is very valuable for use on ground that cannot be seeded until late in the summer, as it can be sown as late as July..1st and still makes a good crop. Per bu., $\$ 1.50$.

\section{Flax Seed}

MINNESOTA No. 25. A wilt-resisting Flax which is a selection made by the Minnesota Experiment station from stock received from the department of agriculture at Washington. Fine seed recleaned for seeding purpose. Price on application.

\section{Barley Seed}

SIX ROIVED. There are many who want to ob tain or change their seed of barley, but who do not want to pay the price necessary to ask for the newer sorts. This is a good standard sort Price on application.

\section{Dwarf Essex Rape}

An annual plant of the cabbage family, grows rery quickly in any weather and makes a big, loose bunch of leaves, somewhat like cabbage Feaves, but long and narrow; grows all summer without going to seed. When eaten off it sprouts up from near the ground. All kinds of stock eat it readily and thrive on it, but most valuable for hogs, especially young stock. Broadcast, 5 lbs. per acre on well-prepared land early in the spring, and after it gets started it will keep a dozen shoats to the acre all summer without other feed. Price subject to change. Per 1b., 15c; per 100 lbs., $\$ 10.00$.

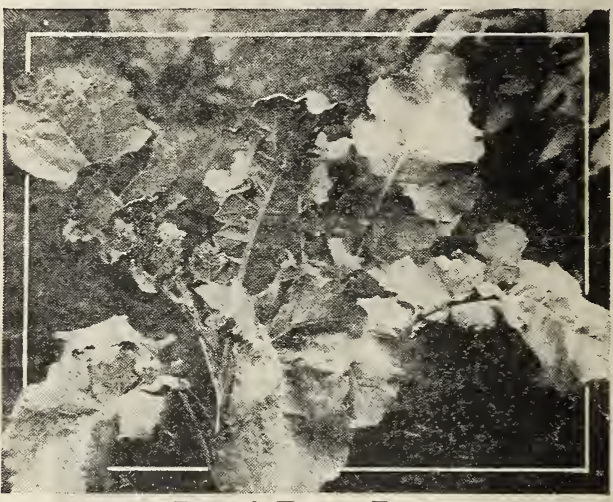

Dwarf Essex Rape

\section{Cowpeas}

Culture. Cowpeas should not be sown until the ground is thoroughly warm, say about the time corn is coming up. They should be drilled. as they do much better that way than broadcast. Can be some times drilled with a wheat drill, using one bushel per acre Could be also drilled with a corn-planter, leaving them either full corn-row width or straddling the rows and making them closer together. In this way you use from a peck to a half bushel per acre. They can be grown for hay or green feed, or can be plowed under for green manuring. For the cornbelt country the Whippoorwill and New Era are the two best varieties. Price on application.

\section{Canadian Field Peas}

This is the variety of peas grown so extensively in the North and Northwest as a field crop. They are somewhat similar to the ordinary garden pea, but make longer vines and more pods. They should be sown very early in the spring, either alone or with oats or barley at the rate of from one to two bushels per acre. They may be cut and cured for hay or let ripen and threshed like small grain. Price subject to change, per $1 \mathrm{~b} ., 10 \mathrm{c}$; per bu., \$4.00. Bags extra.

\section{Soy or Soja Beans}

Northern Grown. Valuable for hay or soiling food for cows, hogs and sheep pasture, also green manure. They resemble the navy bean in general appearance. Like clover they are great soil enrichers, gathering in nitrogen from the air and storing it in the soil. Many tests show that they may be grown wherever corn will ripen. They should be planted after corn in rows $2 \frac{1}{2}$ feet apart with 6 to 8 plants to the foot of row if grown for the beans, requiring about one half bushel of seed per acre. When grown for hay, it is preferable to plant the rows closer together or sow broadcast, at the rate of 40 lbs. per acre. Price on application. 


\section{Syrup Cane Seed}

Ames Amber This is a new syrup producing bred up by the College at Ames, Iowa, and it is one of the greatest sap producing varieties of sorghum in existence. It makes a better flavored variety of syrup and ripens in this climate earlier than any other variety and has been cut last year in just ninety days from the time it was planted, with a yield of about 200 gallons to the acre. In the northern half of Iowa it can safely be planted as late as the first to tenth of June. Per lb., in the head, 20c; 6 lbs. for $\$ 1.00 ; 10 \mathrm{lbs}$. for $\$ 1.50 ; 25$ lbs. for $\$ 3.00$.

Short Orange Syrup Cane The Orange type ier stalked than the Amber, but generally later. We have, however, an extra strain of it called "Short Orange" which is the best Orange Cane we have ever found, and while not quite so early as the Amber, it is very sweet and makes a very heavy yield. Per lb., 20c.

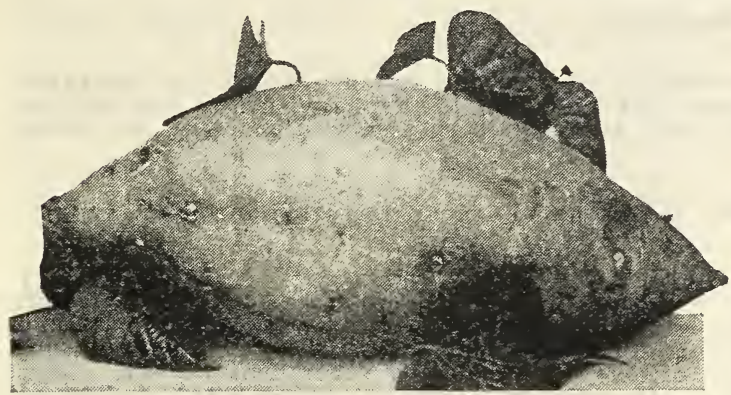

Yellow Jersey

\section{SWEET POTATOES}

\section{Grown Especially for Seed}

The potatoes should be planted in a well prepared hot-bed. We can offer Yellow Jersey (the most popular Northern sort). Lb., 15c; 15 lbs., \$1.25; per measured bushel, \$2.50. Write for special prices on quantity.

\section{SEED POTATOES}

All These Prices Subject to Market Changes

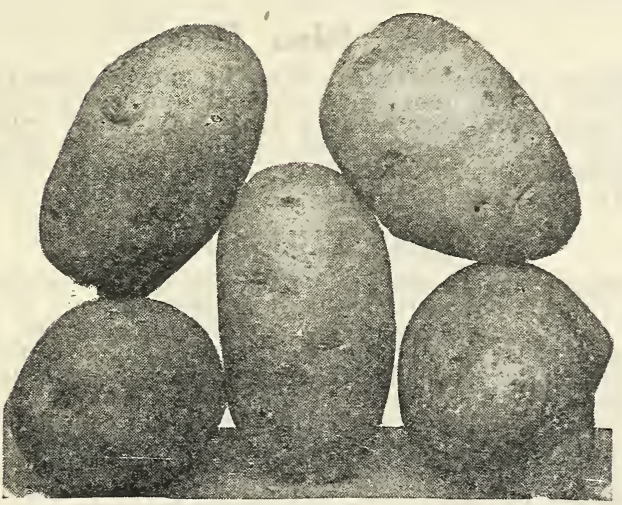

Red River Early ohio

Red River Early Ohio The stock of Early grown in the Red River Valley of the North. They are from ten days to two weeks earlier than common stock; are pure bred and free from scab, and were raised especially for seed. If you want something earlier than anything else, don't fail to get a few bushels of these choice earliest. Price: Pk., \$1.00; 1/2 bu., \$1.25; bu., \$2.00.

Irish Cobbler Potato One of the most valulrish able first early potaform in size, pure white. Pk., $\$ 1.00 ; 1 / 2$ bu., $\$ 1.50$; bu., $\$ 2.00$.

Red River Triumph The Triumph is the The tubers are nearly pound, smooth, medium in size, reddish pink in color. Price: $1 / 2$ bu., \$1.25; bu., \$2.25.

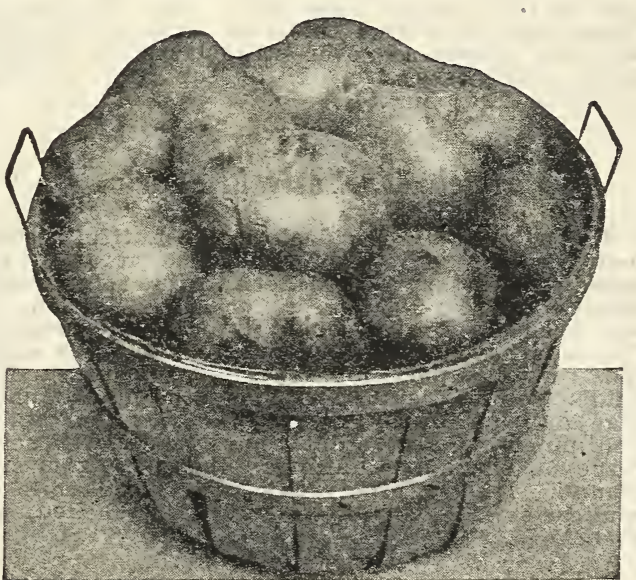

Carman No. 3

Carman No. 3 This potato is of large and mense crops. It uniform size, yielding imbut a few eyes, and they are shallow; the skin and flesh are extremely white, and its cooking qualities are very fine. It is a remarkably handsome potato, enormously prolific. Per pk., $\$ 1.00$; bu., \$2.25. 


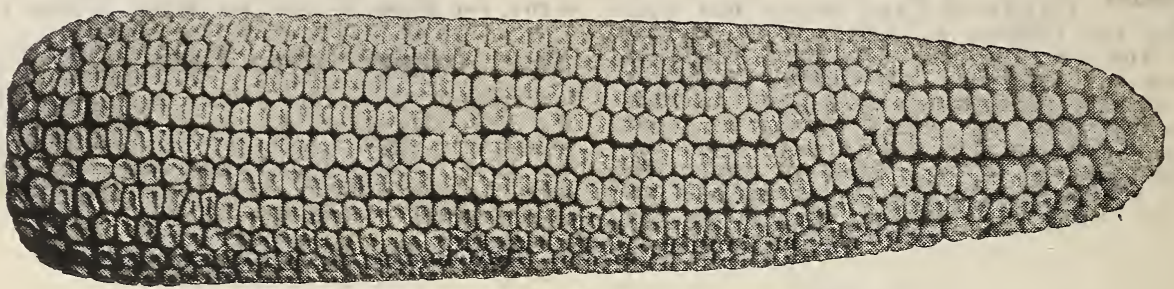

Pride of Minnesota

Our seed corn is grown here in the North, acclimated, selected and tested. We give no guarantee of crop, either expressed or implied, or guarantee of any kind, but if anyone wishes to test our seed corn before planting and is not satisfied with the test, he can return the seed and get his money back.

ALL PRICES SUBJECT TO MARKET CHANGES. Write, phone or call for price on quantity.

\section{Pride of Minnesota}

This splendid new early yellow dent corn originated in the central part of Minnesota on the Minnesota River Bottoms west of Mankato. It is a well-established cross between the early, short-eared yellow corn known as Minnesota No. 13 and Reid's Yellow Dent. Bred in the climate of Minnesota it makes a variety of great importance to the farmers in the southern Minnesota counties and the northern half of Iowa. It is about a 100 -day cropper and retains in size of ear nearly the length of Reid's, slightly more tapering. A great yielder and very much earlier on account of its parent blood of Minnesota No. 13. Length of ears 8 to 10 inches; stalks strong and vigorous. As a seed proposition it is much stronger in germinating properties than the regular Reid's and more certain to come up and grow under severe conditions which often happen in the spring time after corn is planted. Those who have tried this corn in the Iowa corn belt this season are over-enthusiastic on account of its earliness, size of its ear and yielding qualities. Per bu.,.\$1.50.

\section{Michael's Early Murdock}

Michael's Early Murdock. A beautiful yellow Dent variety, well adapted on account of its extreme earliness, to Southern Minnesota, South Dakota and the Northwest Corn Belt Section. It was bred up in Wisconsin by careful selection. The ears have well filled out tips, 16 to 20 rows, and very compact on the cob, something like Reid's Yellow Dent, fairly smooth on the outer edge and uniformly a rich yellow. The stalks medium in height, stout and stocky, with ears borne at regular, uniform distance from the ground. It is a ninety-day variety. Sample on application. Price for selected seed, shelled, per bushel, \$1.50.

\section{The Improved Leaming}

The Improved Leaming. The Improved Leaming corn is a medium early yellow variety; large, slightly tapering ears, good grain, and medium sized red cob. It is one of the seven varieties recognized by the Illinois Experiment Station, where it has been first in yield more times than any other variety in "test of varieties." per bu., \$1.25.

\section{Silver King}

Silver King has almost revolutionized corn growing in Southern Minnesota, South Dakota and Northern Iowa. It will yield more bushels of fine corn than any other dent variety.

Description. Ears averaging 8 to 9 inches, always filled out clear to the tips, and very uniform in size and type. The corn is pure snowwhite in color with good length kernels set compactly in straight rows. The corn is a strong grower, early enough to mature as far north as Oshkosh, Wisconsin, and is especially adapted to resist cold weather. It has a decided doubleear characteristic, one reason for its tine yield records. Per bu., $\$ 1.50$.

\section{lowa Silver Mine}

Iowa Silver Mine. This is more generally grown throughout the corn belt and more widely and favorably known than any other white gorn. It is a sure cropper, middling early, deepgrained, pure white, and a good corn in every way. Per bu., shelled, $\$ 1.25$.

\section{Reid's Yellow Dent}

Reid's Yellow Dent. This corn is light golden in color. The ears are 9 to 11 inches long; 18 to 24 rows of kernels, each containing 50 to 60 kernels. The cob is completely covered with solid corn. The kernels are moderately rough, rather narrow, medium in thickness, knit very closely. together, with no lost space between the rows, and of all corn this is easiest to shuck. Shelled, per bu,\$1.50; on ear, in burlap bag, per bu., \$2.25.

\section{Smut Nose Flint}

Smut Nose Flint (8-rowed). A yellow flint corn blazed with red at one end. This is a very early variety, and a great favorite in many localities. Average length of ear, 10 inches. Average height of stalk, about 7 feet. Average distance base of ear from ground, 3 feet. Per. bu., $\$ 2.00$.

\section{POPCORN}

Japanese Dwarf Rice. A very tender and almost hulless popcorn. Ears short and chunky; heavy yielder and is regarded as the coming commercial variety and the right and the proper thing to raise now to get the highest market price in popcorns. Price on ear, 15c per lb., 10 lbs., $\$ 1.00$.

White Rice. Most popular grain pointed rariety. Price: $121 / 2$ c per $1 b$. on the ear; $10 \mathrm{lbs}$., $\$ 1.00$.

We have other varieties of field corn and shall be pleased to quote prices on application for any other variety suited to our climate. All prices subject to market changes. 


\section{DEPARTMENT OF BULBS, ROOTS AND FLOWERING PLANTS}

\section{Peonies}

Peonies. These big hearted flowers are as much liked today as they were by our grandfathers a century ago. Peonies will grow and do well anywhere pie plant will grow. Give them a deep, rich soil, plenty of barnyard manure, or better still, manure from the hen house, and they will repay you one hundred fold. The Peony, once planted, lasts a generation and grows better every year. They are perfectly hardy and need no winter protection whatever.

Festiva Maxima Peony Is the Queen of all. tion, with every point of excellence. Without exception the plant itself is one of the hardiest. most robust and powerful growers of the entire list of peonies. The flower, a glorious form of purest white combines great size with wondrous beauty. Flecked here and there with a speck of crimson which seems to bring out the white in clearer relief. 3 to 5 eye roots. Price: Each, 40c; Large undivided Field Clump, \$3.00.

Edulis Superba Exceedingly fine, vivid rosecolored flowers, high, full center, very compact, very early and free blooming, highly perfumed. The best fragrant rosecolored peony. 3 to 5 eye roots. Price: 35 c each. Undivided clump, \$2.50.

Felix Crousse. The ideal self-colored red Peony; Felix Crousse. large, globular and compact, an even shade of bright red without trace of any other color; a strong, vigorous grower. 3 to 5 eye roots. Price: 75e each. Large undivided clump, $\$ 3.00$.

Golden Harvest Flower creamy yellow with guards, 3 to 5 eyes, 50c markings and blush clumps, \$2.50.

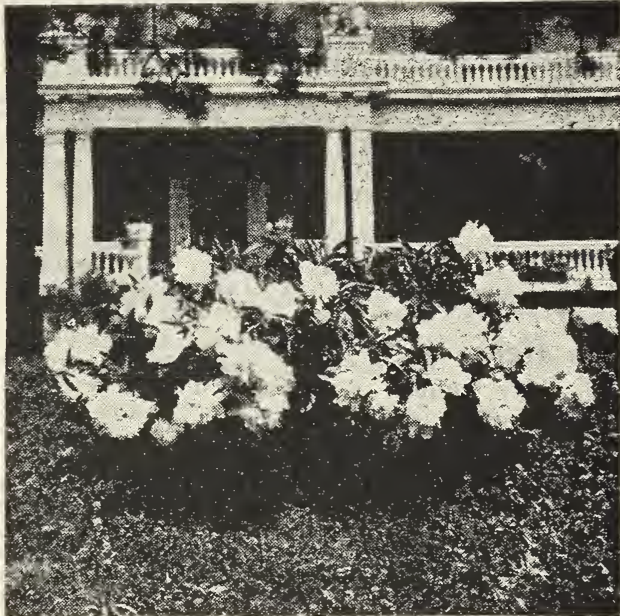

Humei Sweet scented carmine pink with imeye roots, 35c each. Large 3-year old undivided field elumps, $\$ 2.00$ each.

Mixed Peonies Our Mixed Peonies are made up of broken lots of our very best named varieties, some of which are worth five times the price we ask for them. Price: 25c each; 6 for $\$ 1.40$.

\section{Dahlias}

As a home flower nothing equals the Dahlia. Plant the roots two feet apart, about four inches deep; lay them flat on side.

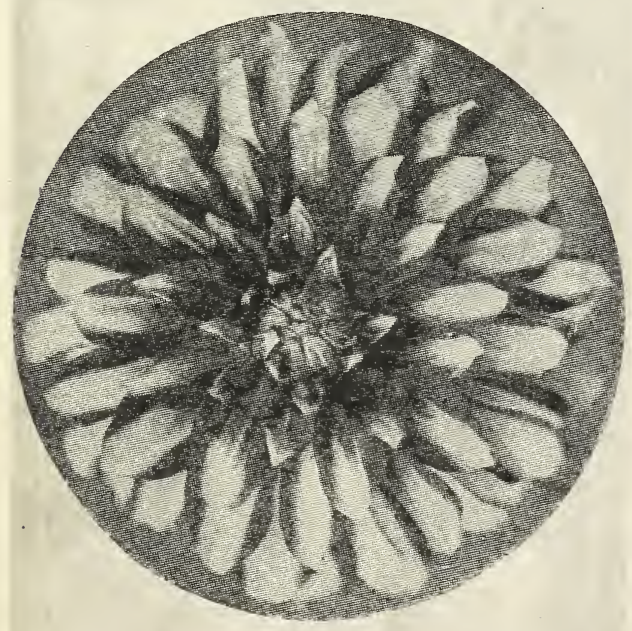

American Beauty Brilliant, crimson red, rich shade to the American Beauty Rose. One in the most prolific bloomers ever introduced. Price, 25c each.

Souvenir Douzon (Decorative). An immense als and full to the center. The largest red in the decorative section. Price each, 25c.
Purple Manitou Immense flower; often solid mottled with purple in color's sometimes $25 \mathrm{e}$ each.

Tango Masterpiece A gigantic flower of clear, 作 ing; borne on long stems. Blooms early and continuously through the season. Color, clear rich tango. It is indeed a masterpiece. Height, 4 feet. Price, $35 \mathrm{e}$ each: 3 for $\$ 1.00$.

Delice Its beautiful soft, yet lively color, a glowing rose-pink, together with its perfect shape, stout, stiff stems, which hold the flowers well above the foliage. Price 25c each; 3 for roc.

Moonbeam (1916). (Decorative). An immense flower, borne on excellent stems. of the light yellows. Plant a sturdy grower. Blooms very freely and an excellent keeper when cut. Price, 25c each.

Gaiety A superb new decorative, vivid scarlet, are long and flowers are produced freely. Price, 25c each.

Mrs. Winters (Decorative). This superb white Dahlia is generally and favorDivays reliable, always satisfactory. As a white it has neither superior nor equal. Price: 25c each.

D. M. Moore (Show). A flower of mammoth long, stiff stems. Its color is a deep, velvety maroon. It has no equal in its color. Price, each, 25c.

Souvenir Franz Liszt (Peoneo flowering). Veined and shaded with white. Flowers very large. Price, each 35c.

Mixed Sorts Various colors and kinds, mixed. Price, each, 15e; 2 for $25 \mathrm{c}$. 


\section{Canna Roots and Plants}

The king of bedders. The plant requires deeply dug, well enriched soil. . Plant when ground is warm. Set the taller kinds for the center'and dwarf kinds for the outer edges. Canna plants ready about May ist.

King Humbert (4 ft.) Bronze foliage. Velvety, mine. heartshaped ears of a deep purple. Price: per root, 15e each; doz., \$1.75.

Beacon ( 4 to $4 \frac{1}{2}$ ft.) Heavy, lateral growing rich green 1oliage. Flowers of very rich cardinal, which are produced in great masses. Its immense flowers with handsome foliage are very striking. Per root, $15 \mathrm{c}$ each; 3 for $40 \mathrm{c}$; doz., \$1.50.

Wyoming (7 ft.) Purple foliage. One of the ange colored, true Orchid shape, with large, rounded petals. Per root, 10c; doz., \$1.00.

Queen Helen (Yellow Humbert). Identical with Queen helen bronze King Humbert in growth. Flower pure yellow, sometimes dotted with red and sometimes the petals are red and yellow mixed. The foliage rich green. Size about $41 / 2$ feet. Roots, 15c each; $\$ 1.75$ per doz.

The President The best new Canna yet introThe President duced, flowers a glowing scarlet of immense size; foliage rich green, broad leaf of lateral growing habit, borne on a stout, heavy stock about 4 feet high. This combination of flower, foliage and stock are qualifications of special value in the enchanting effect in any bed of Cannas. Roots 25c each, \$2.50 per dozen.
Musafolia (8 ft.) Green foliage with Bronze Musafolia border. Grown for foliage only, which on account of its enormous Mussa-like leaves is used for making screens and backgrounds. Per root, 5c; doz., 50c; 100, \$3.75.

\section{CANNA PLANTS (Potted)}

Canna Plants. The Canna is a tender, subtropical plant; roots easily affected by severe weather changes and often rot in the ground by being planted too early. The most effective way of planting them is to use plants which are started in a greenhouse early in the season and in 4 in. pots having 2 to 5 leaves on them by the first of May, at which time, weather permitting, they can be planted outdoors.

Per Doz.

Wyoming, Tall bronze, orange orchid flower grown in 4 in. pot .................. $\$ 3.00$ Beacon, Dwarf Green, red orchid flower grown in 4 in. pot ...................................... 3.00

Humbert, Dwarf bronze orange scarlet flower grown in 4 in. pot ............................ 3.00 Musafolia, Tall green foliage, red flower grown in 4 in. pot ............................. er grown in 4 in. pot. Each, 35c ................ 4.00 Queen Helen, Medium size green yellow flow-

er grown in 4 in. pot. Each, 25c ................ 3.00

\section{Gladiolus Bulbs}

Gladiolus. Planted every two weeks from time soil can be cultivated until July; will give a lot of bloom from June until cut down by frost. Plant 6 inches apart in rows. The varieties listed below are a selection of the finest and most distinct kinds, including the sorts best suited for our soil and climate. We quote only first size, first quality bulbs.

America Soft lavender pink, very light, almost a immense flowers, first size bulb. 5c each; doz., $40 \mathrm{c}$; per $100, \$ 2.75$.

Empress of India Dark, blackish-red, the darkest and extremely rich, first Gladioli; immense flower, $\$ 1.00$.

Mrs. Frances King Effective Flower spike with a Mood line of reserve buds conmilion scarlet. Each, 5c; doz., 50c; per 100, $\$ 3.00$.

Panama A new seedling of America, which is a flowers large and well arranged, first size bulb. Each, $8 \mathrm{c}$; 2 for $15 \mathrm{c}$; doz., 75c.

Peace Flowers are large with good form, correctly 6e each; doz., 60c.

Princeps The flowers are 5 to 6 inches broad. The color is brilliant scarlet crimson, earrying y three broad, white blotches on the lower petals, first size bulb. Each, 10c.

Niagara In color the flowers are a delightful cream ments blending to a canary yellow. The throat is splashed with carmine, first size bulb. Each, 8c; doz., 75c.

Willy Wigman Beautiful large white flower with throat of the lower petals, first size bulb. Each, 6c; doz., 60c.

War Deep blood red, shaded to an almost black tive and enchanting. 8c each; 2 for 15c; doz., 75c.

IMPORTED BULBS MIXED. First size, first quality bulbs, beautiful blend of colors. Doz., 35c; $\$ 2.00$ per 100.

NATIVE MIXTURES. All kinds home-raised bulbs. Doz., 25e; \$1.75 per 100.

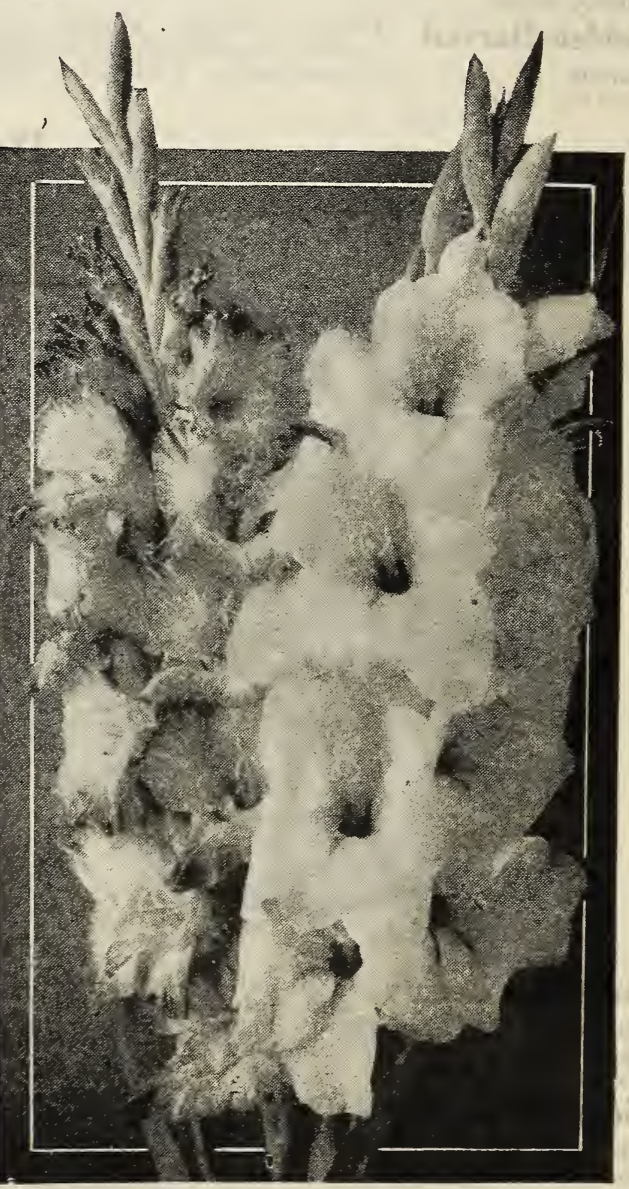




\section{HERBACEOUS FLOWERING PLANTS, ROOTS AND BULBS}

\section{Lilies}

Auratum Lilium (Gold Banded Lily). The grandest of all hardy Lilies; flowers white, spotted with maroon, having a bright yellow band through each petal. Each, 25c; doz., \$2.50.

Auratum Rubrum (Lily). Enormous flowers, Auratum Rubrum sometimes measuring 10 inches across; pure white, beautifully spotted and with a deep crimson stripe. Each 25 ; doz., $\$ 2.50$.

Lily Album One of the mrost popular of all each, 25c; per doz., \$2.50.

Lily Tigrinum (Tiger Lily). Single and hardy with purple. Price each, 25e; per doz., \$2.50.

Lily Tigrinum (Double Tiger Lily). Well blossom. Price each, 25c; per doz., \$2.50.

Lilium Candidum (Madonna or Annunciation oldest, loveliest and Lily). This is one of the flowers are snow whitest known Lilies. The ful fragrance. Each, 25c; doz., \$2.50.

Lily Funkia The bell-shaped bluish lavender Llowers are produced on a flower stock 3 to 4 feet high. Each, doz.,

Lily of the Valley The most charming of the Ling perennials. each, 5c; doz., 50c; large clumps, each, $25 \mathrm{c}$.

\section{Hardy}

Bleeding Heart An old-fashioned favorite, forcing as for planting the open border. Price: Clumps, each, 60c.

Campanula (Bell Flower). Bell-shaped flower's, well known and most easily grown. Price: Field Clumps, each, 25e; doz., \$2.75.

Columbine (Rocky Mountain). (The Colorado Columbine State Flower). Flowers very large; lavender and white; each root forms a large clump. Each 25c; doz., \$2.50; Potted Plants, doz., $\$ 2.00$.

Coreopsis Grandiflora A showy border plant Coreopsis Grandiflora with large, handsome orange yellow flowers; blooms through the season. Each, 20c; doz., \$2.00.

Delphinium (Hardy Larkspur). Few plants Delphinium are so handsome in the garden as these perennial Larkspurs. Each, 25c; doz., $\$ 2.75$.

Chrysanthemums These are gaining in poputhe reason that they establish themselves to withstand the severity of winter.

\section{outdoor Variety}

J. Lagravere. Rich garnet, large flower... Each, $25 \mathrm{c}$; per doz., $\$ 2.75$.

St. Illoria. Silvery rose, quilled perennial. Each, 25e; per doz., \$2.75.

The Hub. Large, double white flower.Each, $25 \mathrm{c}$; per doz., \$2.75.

Yellow King. Large double yellow flower. Each, $25 \mathrm{c}$; per doz., $\$ 2.75$.

$1 / 2$ doz., either variety, $\$ 1.40$.

Golden Glow (Chrysantliemum). A large, very showy plant, attaining a height of six feet, producing hundreds of flowers resembling yellow Chrysanthemums. Each, 15e; doz., \$1.5e.
Dianthus (Hardy Garden Pinks). Charming summer flowering border plants, more or less fragrant. Two-year clumps, each, $20 \mathrm{c}$; doz., \$2.25.

Digitalis (Foxglore). 3 to 5 feet. Stately old garden favorites for garden and places. Field Clumps, each, 25c; doz., \$2.75.

Gaillardia A showy flower, beginning to bloom season. Petals vary from scarlet-orange to crimson. Field Clumps, each, 25c; doz., \$2.75.

Hardy Phlox This is one of the most attractive flowers in summer decoration. Colors range from bright red to deep crimson. A hardy perennial, once planted they last for many years.

Mîss Lingard. An ever-bloomer, pure white, earliest of all. Price, per each, 25c; per doz., $\$ 2.50$.

Richard Wallace. White, with red eye. Price, per each, 25c; per doz., \$2.50.

Rosenberg. Reddish-purple, very large flower. Price, per each, 25c; per doz., \$2.50.

Mixed Phlox. Price each, 10c; per doz., \$1.00. Hollyhock Roots This old-time flower appeals to our sentimental affecgood back-ground for the lower growing plants. Separate colors, pink, white, crimson or yellow. Roots, each, 15c; doz., \$1.50.

Shasta Daisies (Alaska). Immense snow white flowers. Bloom through the season. The best daisy in the list. Each 25c; doz., \$2.75.

\section{Not Hardy}

Begonias (Tuberous-Rooted). For brilliancy of color, duration and profusion of ous-rooted. Begonias offered. Price on application.

Elephant's Ear (Caladium Esculentium). Grand tropic-looking plant. In rich soil, if freely watered, they will produce enormous leaves, frequently four feet long, three feet wide. Height, 4 to 5 feet. Fair sized bulbs, each, 15c; medium sized bulbs, 25c; monster giant bulbs, 50c each.

Tuberoses Large blooming bulbs; this is one Tuberoses of the bulbs all should have. Synonym of sweetness and purity. Price: Each, 5c; 12 for 50c.

Montbretias One of the brightest and most July to October they are one mass of blooms; graceful, bright and cheery. Each, 5c; doz., 50e.

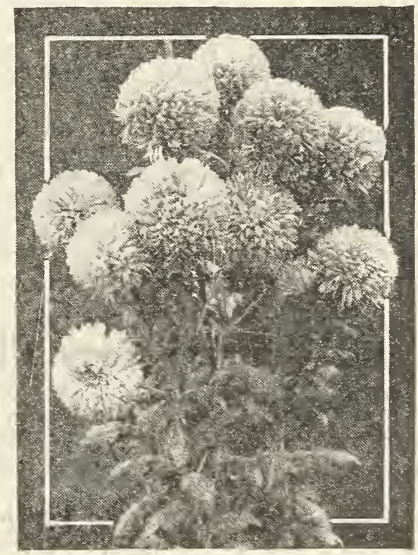

Hardy Outdoor Chrysantlemums 


\section{Hardy Irises}

(FLECR DE LIS)

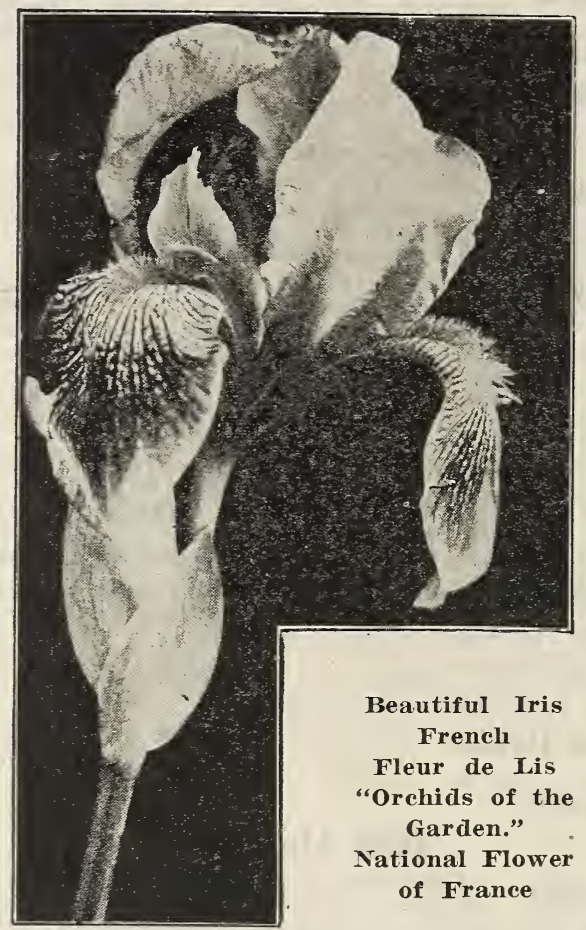

There is a peculiar charm about the Iris that appeals to all lovers of the beautiful in flowers. The blossoms are of rich and varied colors, quaint forms and some varieties are very fragrant.

Culture. A very sunny location suits them best. They can be planted in the spring, but the most favorable time is after blooming, late summer or early autumn.

Mixed Iris These are made up from choice in brilliant colors. Each, 5e; doz., 50c; 50 for $\$ 1.75$.

Florentine Alba Very large flower, pure white and rare. Each, 10c; doz., 75c; per 100, $\$ 5.00$. Pallida Dalmatica one of the most beautiful Exquisite shade of larender. Each, 10c; doz., \$1.00. Juniata Standard petals and falling petals ; Juniata clear blue; large, fragrant flower. The tallest of the Bearded Irises, with unusually long, drooping foliage. Noted for its fragrance. Each, 35e; 3 for $\$ 1.00$.

Kochii Richest of all the clear dark purple, the Black Prince type. Each, 15c; doz., \$1.50.

Dwarf Iris (Chamari). Very dwarf. Earliest Dwarf Iris bloomer of all, blooming early in work. Each, 5c; doz., 60c; 100, $\$ 4.00$.

\section{House and Conservatory Plants}

Asparagus Plumosis (Lace Fern). Fine for able for hanging baskets and porch boxes. 6inch specimen plants, each, $\$ 1.00 ; 4$-inch pots, each, 50c.

Asparagus Sprengerii (Emerald Feather). For boxes and hanging baskets. Price: for porch doz., \$2.50; 4-inch, 25e each, \$3.00.
Cyperus Alternifolius (Umbrella Plant). Explant. 3-inch pots, each, 50c; 4-inch pots, each, 75c.

Dracaema Indivisa Much used for vases, win5-ind dow boxes and hanging -inch pots, each, $\$ 1.00 ; 6$-inch pots, each, \$1.50.

Boston Ferns Long, graceful, drooping fronds. Fern. Each, 4-inch pots, 75c; 6-inch pots, $\$ 1.00$.

Dish Ferns We sell thousands of these handfern dishes. Each, 10c; doz., \$1.00.

Pandanus (Screw Pine) Utilis. Green leaves, red spines. Variegated Veitchi green and white. 4-inch pots, each, $\$ 2.00 ; 6$ inch pots, each, $\$ 3.00$.

PALMS We have Kentia Belmoreana and and Roebelenii; fine plants. Price: 4-inch pots, each, 75c; 6.-inch pots, each, \$2.00.

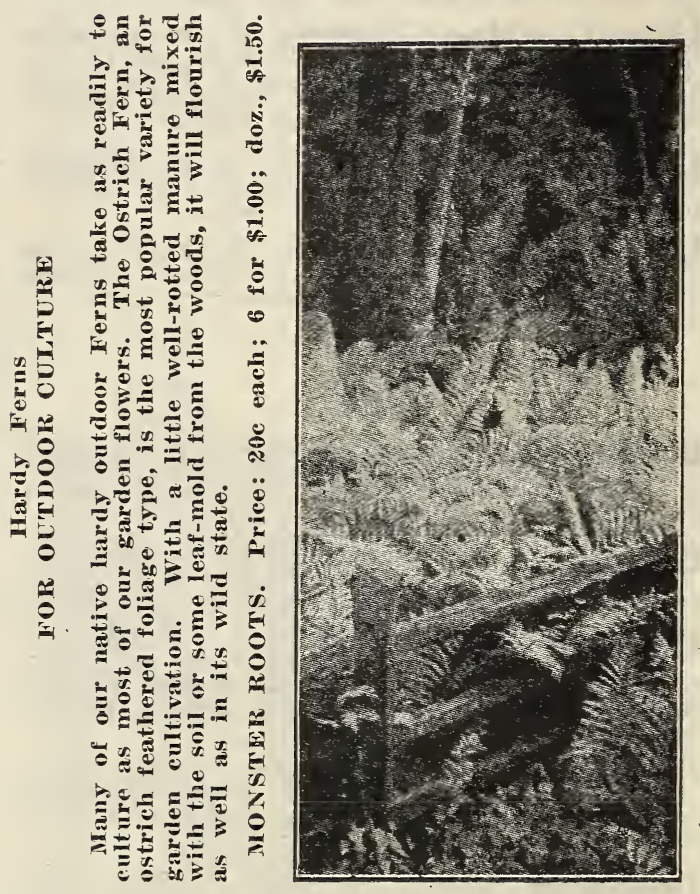

\section{Autumn Planting Bulbs}

FOR FARLY SPRING FLOWERS.

SEASON TO PLANT, OCTOBER AND NOVEMBER.

Hyacinth, Tulips, Narcissus, Jonquils, Crocus, and Snowdrops, which bloom so early in the spring are for autumn planting only.

Many persons, seeing these beautiful flowers all abloom in early springtime, think they can get some, too, right away, but alas, their surprise and chagrin when informed that to have them in Springtime all abloom the bulbs must be planted the autumn before. We have a catalog of all these Bulbs and Herbaceous Perennial Roots for autumn planting, prices, descriptions, etc., free for the asking.

Remember-We hare a complete line of these bulbs in season. September until December. 


\title{
Plant Department
}

\section{Flowering Plants}

\author{
FOR HANGING BASKETS
}

We grow large quantities of all these popular varieties of flowering plants.

Hanging Baskets All filled with beautiful the ceiling on porch or veranda, are charming and attractive to the home. Each, \$2.50 and $\$ 3.00$, according to size and plants used.

Plumosis Hanging Baskets Dark green feathEach, $\$ 3.50$ to $\$ 4.00$.

Sprengerii Hanging Baskets Everlasting rich Price: Eacli, $\$ 3.00$ to $\$ 3.50$. Wire Hanging Baskets empty, 60c each. Green Sheet Moss For lining hanging baskets.

FOR BEDDING, WINDOWBOXES AND VASES Aster Plants American type. American purGiant ple and American Beauty Rose. Giant Branching. Potted plants, doz., 50c; mixed in baskets of 1 doz., $40 \mathrm{c}$.

Coleus Plants For border work. Either variegated foliage. Price: $21 / 2$ inch pots, doz., 75c. Dusty Niller Plants For foliage only; border Price: 21/2 inch pots, doz., 75e.

\section{GERANIUMS}

Prices do not include pots.

Geranium Plants The grandest of all bed Geranium Plants ding plants. Double flowering clark red, pink and white; potted plants only.

S. A. Nutt. Best of the dark crimson-scarlet bediers. Perfectly double and a remarkably free bloomer; blooms all summer.

La Favorite. The best double white bedding Geranium.
Madame Perkins. Large flowering, cerise pink unparalleled for beauty and freshness.

Price: 4-inch pots, each, 25c; doz., \$2.75.

Ivy Leaved. A free flowering variety. Extra fine for porch boxes. Price: Each, 4-inch, 25c.

Mme. Sallerio. The best border Geranium. Foliage variegated green and white. Price: $21 / 2$ inch pots, doz., \$1.00.

Lobelia Plants Easy culture, used in rases Lobelia Plants and border; blue flower. Price: 21/2-inch pots, doz., 75c.

Pansy Plants Mixed colors, finest French 75c. In baskets, earth, basket of doz:, 50c.

Petunia Plants Single large.fringed flowering Italian strains. Price: $\mathbf{2}^{1 / 2}-\mathbf{i n c h}$ pots, each, 15̃c; 3 for 35c; doz., \$1.00. Double flowering sorts, each, 25c; doz., \$2.50.

Salvia Plants Richest scarlet flower; finest of Salvia Plants all bedding plants; long spikes of dazzling red, lasting all summer until frost. Price: $21 / 2-$ incl pots, doz., \$1.00; 4-incli pots, doz., \$2.50; growing in baskets, earth, basket of doz., $50 \mathrm{c}$.

Sprengerii (Enerald Feather). For foliage only Price: 3-inch pots, doz., \$2.50; 4-inch, 25c each. $\$ 3.00$.

Verbena Plants Single plants of this pretty annual creeper will carpet a pace 8 to 10 inches in diameter with meat foliage and scores of fine flowers. Price: All colors, $21 / 2$-inch pots, doz., $75 \mathrm{c}$; growing in basket of eartl, basket of doz., 50c.

Vinca Vines For foliage only; variegated and green; hanging baskets and porch boxes. Price: $21 / 2$ inch pots, doz., \$1.50; 3 -inch pots, doz., \$2.25; 4 -inch, 25c each, \$3.00.

\section{Vegetable Plants}

We grow large-quantities of Vegetable plants and Roots, and can supply all the varieties listed below in their proper season. Well grown and packed to carry a long distance, they can be shipped from the beds on a day's notice. All prices subject to season conditions, stocks on hand and change at time of purchase. Write for spring prices.

Cabbage Plants Transplanted plants, early sorts ready May 10th. Doz., 15c; 100, \$1.00.

Cauliflower Plants Early Snowball and secCauliflower Plants ond early. Transplanted Plants. Doz., 25c; 100, \$1.75.

Celery Plants Ready May 10th. Seedling stock. Transplanted stock, per 100, \$1.50.

Egg Plants In pots or growing in basket of Egg Plants earth only. Basket earth, 50c Potted plauts, doz., 60c; in bulk, per 100, \$1.50.

Pepper Plants Bull Nose and Chinese Giant in Pepper Plants bulk. Doz., 25e; in basket earth, growing, doz., 50c; in bulk, 100, \$1.50.

Sweet Potato Plants Ready about May 5th. Sweet Potato Plants Yersey plants. Price: 100 plants, $75 \mathrm{c} ; 500, \$ 3.25 ; 1,000, \$ 6.00$.

Horseradish Large roots, each, 10c; doz., 75c; Special price in quantities.
Tomato Plants Dwarf Champion (Tree). Ready ny Best and about May 1st. Earliana, Bon growing in basket earth, basket, 25c; Potted plants, 2-inch pots. Fancy plants, doz., כ0e; Transplanted Plants. Loose in bulk. Doz., 15c; $100, \$ 1.00 ; 1,000, \$ 7.00$.

Seedling Plants. 100, 50c; 1,000, \$4.00.

Asparagus Roots Crowns should be set early in spring or late in fall. old roots. Doz., 25e; $100, \$ 1.50 ; 1,000, \$ 10.00$.

Rhubarb or Pie Plant (wine Plant). Roots can be planted either fall or spring. Choicest large sorts, roots, each, 10c; doz., $\$ 1.00 ; 100$, $\$ 7.50$.

Chives Perennial plant. Per clump, 25̃.

Mint (Spearmint). Per clump, 20c. 


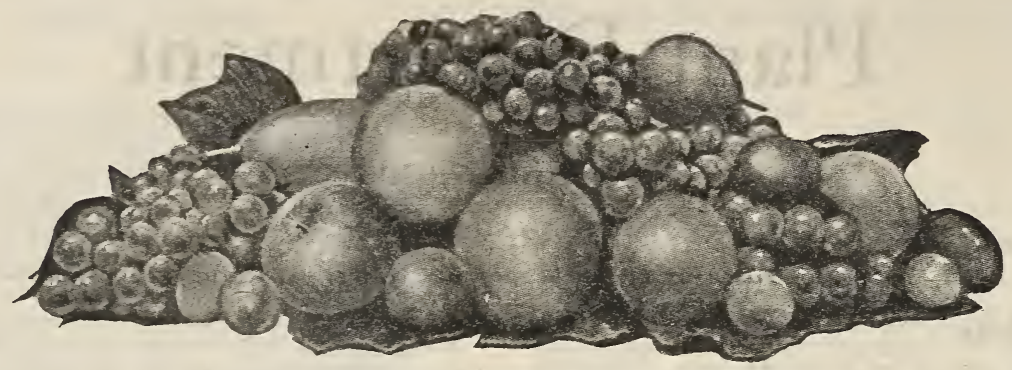

\section{NURSERY DEPARTMENT}

MPORTANT TO PROSPECTIVE CUSTOMERS OF ROOTS, BULBS, PLANTS, NURSERY STOCK, ETC.

We handle only such kinds and varieties of trees, shrubs and plants as grow here and stand this climate. Stock strong, true to name, dug when wanted and roots carefully packed in wet moss for shipping. All prices subject to market ohange.

OUR NURSERY DEPARTMENT is in the basement of our concrete seed store building at 316 Pearl Street. well lighted with electricity as a salesroom and an ideal place for keeping nursery stock, bulbs and roots just as fresh and nice for two or three weeks as though they were dug out of the ground and where too, there can possibly be no effect from weather changes that are often severe, damaging shrubbery after it is dug in the spring time and before it is planted.

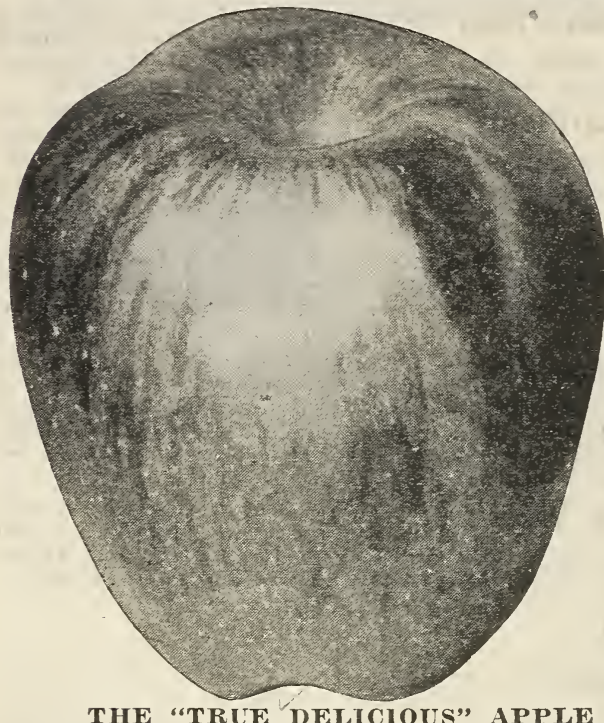

Delicious originated twenty years ago at Peru, Madison Co., Iowa. The original tree still flourishes, bearing an annual crops of beautiful fruit. Fruit is large, with the surface almost covered with a most beautiful brilliant dark red, blending to golden yellow at the blossom end. In quality it is unsurpassed, flavor slightly acid, delightfully fragrant, flesh fine-grained, crisp, juicy, melting and delicious. Good keeper, coming out of storage in March or April in perfect condition. 5 to $6 \mathrm{ft}$. select trees, 75c each.

\section{Summer Apples}

Yellow Transparent One of the earliest apgood bearer. Two-year old trees frequently produce fruit. Medium large, smooth transparent. Skin is pale yellow when ripe. Flesh white, and splendid quality. Does well most anywhere. Is perfectly hardy.

Duchess of Oldenburg From Russia, extremeyellow with red stripes. Somewhat sour, fine for cooking. A couple of these trees should be in every orchard. Will not keep long when fully ripe. 5 to 6 foot trees, roc each.

Prices quoted are for select, hardy trees, adapted

\section{Fall and Winter Apples}

Wealthy A seedling originated in Minnesota; very arge, durk crimson; flesh crisp sub-acid, white tinged with red; good quality. Tree a fine, upright grower, oth in the nursery and orchard. Season, October ecember. 5 to $6 \mathrm{ft}$. trees, 75c each.

Intosh Red Canadian (Ontario) origin; extremely hardy and does well even in the exposed cold regions of Montana and Wyoming and very popular in the Northeastern states. It bears a ig red apple above medium; a beautiful crimson ; lesh snow white; slightly acid and a wonderful keeper. It is growing more popular wherever it is known.

Hibernal Russian origin. Absolutely hardy in this climate. It represents the hardiest of all ussian races of apples. Tree vigorous, wide-spreading and productive. Fruit very large with a dull bronze color over a greenish yellow. Flavor sub-acid, plendid for cooking. It is often used as a main stalk or limb grafting of other varieties. 5 to 6 foot trees,

owa Blush Originated in Iowa. Tree very fruitful, strong grower: Fruit ther conical, surface sinooth, yellow, with bright mottled red blush, white flesh, juicy and rather sub-acid. November to fanuary is the season it is good to eat. 5 to $6 \mathrm{ft}$. trees, $70 \mathrm{c}$ each. Peerless Tree a very fine, straight, upright Duchess, near Fairbault, Minnesota. It is quite hardy and productive; fruit of medium size, color red or a yellow-greenish; perfectly hardy here. 5 to 6 ft. trees, 70c each.

Northwestern Greening Tree of Wisconsin fine shaped. origin and extremely froenish-yellow; June. $\tilde{5}$ to $6 \mathrm{ft}$. trees, roc each.

Ben Davis A tree highly esteemed in the Ben Davis West. Fruit conically shaped, striped and of fair quality. Very productive. roc each.

Jonathan A brilliant dark red apple of exand juicy. It is one of the Tender, spicy, rich ties for commercial planting. October to March. 5 to $6 \mathrm{ft}$. trees, $70 \mathrm{c}$ each.

Winesap old favorite, vigorous grower, and er. 5 to $6 \mathrm{ft}$. trees, roc each.

d to this climate. 5 to $6 \mathrm{ft}$. specimen stock. 


\section{Crab Apples}

Whitney No. 20 (Hybrid Crab). Fruit very ple striped red with yellow flesh; rather juicy and grained. Healthy and vigorous tree, upright, rather conical in growth and a beautiful tree.

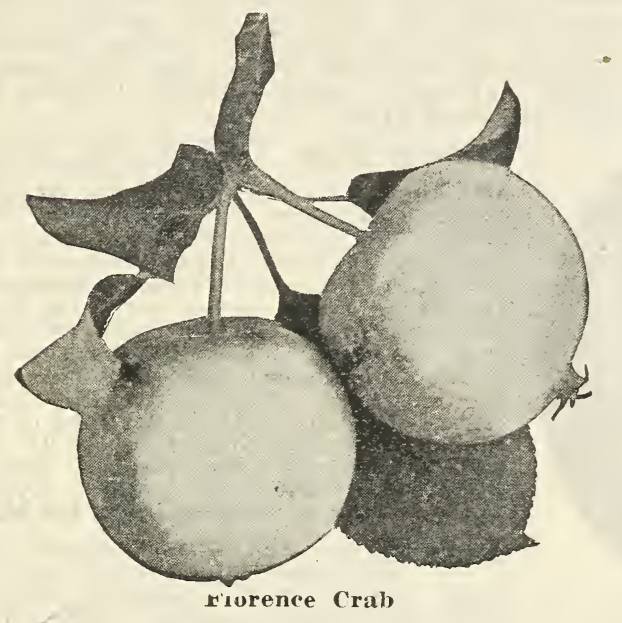

The Florence Crab The most valuable crab beares fruited here. Annual ually fruiting the second season after planting. Early, large, beautiful, excellent, voungest bearer, most prolific of all. Hardiest and most ornamental fruit tree we grow. Exempt from blight.
Red Siberian About an inch in diameter, grown abundantly. August to September.

PRICES: These prices are for selected crab trees', 5 to 6 ft., each, roc.

\section{Dwarf Apples}

The Dwarfed Apple trees we offer are any of the standard varieties, budded on a foreign Ducine (Paradise) Apple stock, which has the effect to dwarf the growth of the standard varieties when budded on this stock. This habit of 'growth makes it essentially a city tree for the reason that the standard Apple grows rather too large for the city garden plot, while these Dwarfs do not attain a great. er size than the Plum tree. Dwarf trees bear when very young, beginning to bear the second year they are out. The usual distance for garden planting of Dwarf Apples is about 6 or 8 feet apart each way but they can be planted in hedgerows and set near together. When planted this way, the tree grows only in two directions and makes a beautiful, ornamental and profitable hedge way or they may be treated espaliers. Varieties we offer: Dutchess, Wealthy, Delicious and Yellow Transparent. 4 to 5 foot trees, $\$ 1.50$ each. 5 for $\$ 7.00$.

\section{CHERRIES}

The Cherry is the most valuable of all fruit trees for the Northwest; perfectly hardy, grows and thrives on anv of our soil. An annual bearer; ornamental as well as valuable.

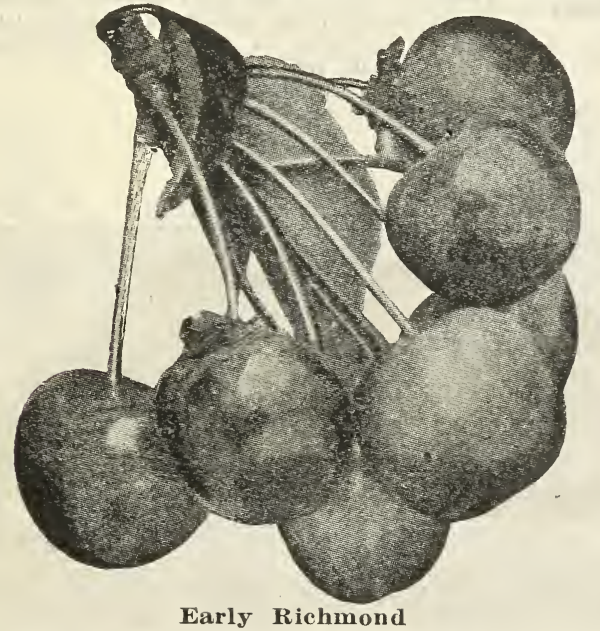

Early Richmond An early red, acid cherry, Tree a free grower, hardy, healthy and very productive. It is the leading market variety for this section. Ripens in June.

Large Montmorency Large, red, acid cherry ; Richmond and about ten days later. Early perior sort for home use.
English Morello Trees very hardy and great the late varieties. Fruit large, round; skin dark red, becoming nearly black when fully ripe; pleasant sub-acid flavor when fully ripe. Season, July and August.

Wragg Originated in Iowa. Large, dark red Wruit, dwarfish growth. Very hardy, vigorous growth. Very heary bearer, fine commercial variety.

Black Tartarian Very large, fruit of purplishBlack Tartarian black color, flesh is mild and sweet. Tree is vigorous, upright grower, and immense bearer. A sweet cherry of the Ox-heart type.

Compass Cherry Plum Absolutely hardy everywhere. Originated in Minnesota. A cross 2herry, Morello Cher60.7 Cherry, Morello CherPlum. The tree is a regular and heavy bearer, and produces fruit the next year after setting out. Its e a rly bearing is truly wonderful.

Compass' Cherry

PRICES: Cherry, standard varieties, very select, picked trees, 5 to 6 feet, each $\$ \mathbf{1 . 0 0}$. 


\title{
PLUMS
}

\section{A LIST OF THOROCGHLY TESTED AMERICAN VARIETIES}

The Plum tree attains its greatest perfection on our heary soils, being entirely free from disease. Plums are very hardy and grow vigorously in all sections.

\section{PROF. HANSEN'S HYBRID PLCMS}

Hanska This is a cross between a wild northHanska western plum and the Prumus Simoni. The flat shape of this plum and its peculiar red color with its heary blue bloom distinguishes Northwest. Tree a very strong grower and very hardy. An early and profuse bearer; quality good. Per each, $\$ 1.00$.

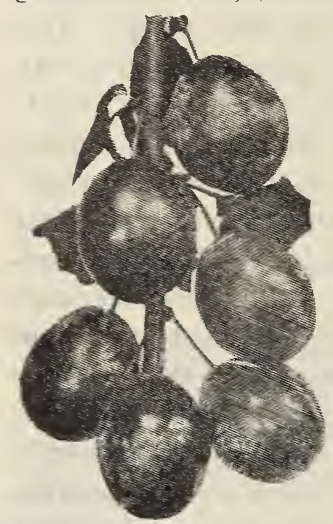

ple red flesh of its Japanese sire. for the prairies of the Northwest.
Opata A cross between the Dak. Sand Cherry large hybrid by Burbank. It possesses the sprightly acidity of the Sand Cherry and rich sweetness of the Gold Plum, the male parent. Season extremely early. Dark tourplish-red fruit. Per each, \$1.00.

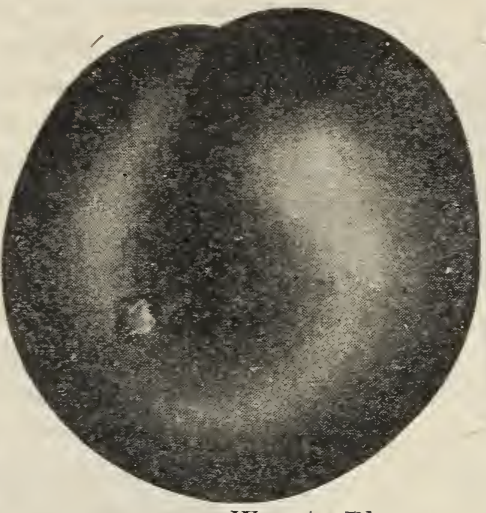

Waneta Plum Waneta Plum This is the largest ten thousand hybrids of the Hansen Hybrid varieties. Size of fruit, two inches in diameter. The tree is a cross with the Japanese Apple Plum and our native Iowa variety (Prunus Americana) the Terry Plum, which bears the largest fruit of all the native or Chickasaw rarieties. Color of the fruit is dark red, flaror delicious; possesses the hardiness of the native Chickasaw parent with the fruiting qualities of the famous Japanese variety; an early and profuse bearer. See picture outside back cover. Price: $\tilde{5}$ to 6 ft., 2-yearold top growth, $\$ 1.25$ each; 5 for $\$ 6.00$.

Sapa This is a cross between the large purple-fleshed Japanese variety, dark purple skin and rich dark purple flesh Plum called Sultan. The fruit has the glossy skin and rich dark purHas attracted great attention as a new departure in stone fruits Per each, \$1.10. כ for \$5.00.

\section{Native Plums}

\section{Chickasaw Varieties}

\section{Terry Plum The largest fruit of any of the Thickasaw or Native plums, fruit ous grower and perfectly hardy. Fruit bright, attractice color, very firm. Price: 5 to 6 ft. trees, $\$ 1.00$ each.}

De Soto Tree is extremely hardy. It comes heavily as to retard the growth of the tree. It is an annual bearer. Fruit good size and quality. Color red at full maturity. Ripens in August. 5 to $6 \mathrm{ft}$. select, $\$ 1.00$ per tree.

Miner Tree a very strong, vigorous grower. Fruit large, deep red and of good qual. ity. A valuable variety to raise. Fruit ripens late. $\tilde{5}$ to $6 \mathrm{ft}$., $\$ 1.00$ per tree.

\section{PEARS}

\begin{abstract}
Seckel (Sugar Pear). Tree rather slow very productire, bearing immense crops of fruit. Small size but of the highest flaror and sweet as honey. The sweetest pear known and is a favorite with everybody who eats it. Should be sprayed once or twice during summer. We furnish in both Standard and Dwarf. Standard Stock, 5 to $6 \mathrm{ft}$., \$1.25 each. Dwarf stock, 4 to $5 \mathrm{ft}$., $\$ 1.00$ each.

Keiffer This is the most popular pear or and good quality; tree very vigorous and seldom blights; should be picked at maturity and ripened indoors. October and November. 5 to $6 \mathrm{ft}$. trees, $\$ 1.25$ each.
\end{abstract}

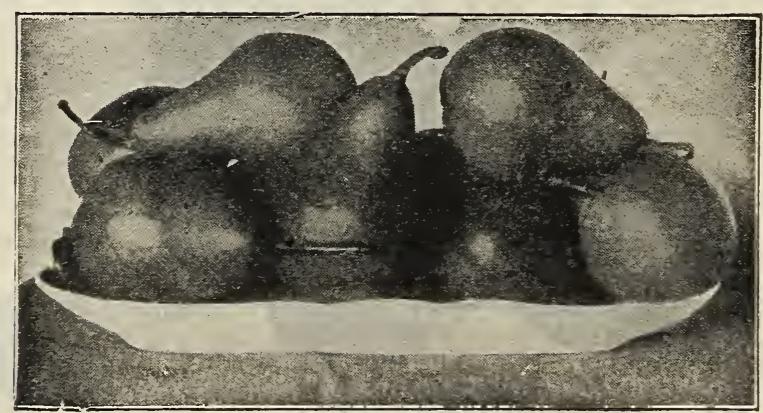

Plate Seckel Pears

\section{Mulberry}

Russian Mulberry Introduced to this country on account of its hardiness makes a beautiful ornamental tree. The fruit much inferior to the native, but is greatly prized by birds, keeping them away from other garden fruit. For hedge size see page 43 . Trees, 5 to $6 \mathrm{ft}$., 50c each. 


\section{Currants}

Hardy, easily cultivated, standing neglect well, indispensable for table use, jellies, etc. Set four feet apart in rich ground. - If the currant worm appears, dust with hellebore.

Diploma This is the largest known variety of Pan-American Medal at the Buffalo Exhibition on account of its size and excellence. It is a strong, upright grower, prolific bearer, beautiful red berries of finest quality.

Red Cross This is another of the large-beras large as the Diploma it has the advantage of being a sweet variety and requires very little sugar when canning.

Fay's Prolific It has given general satisfaction; fruit very large, bright red, and of excellent flavor, less acid than Cherpicking, and is enormously productive.

White Grape Currant Berries large, very productive. Much sweeter cellent for table use.

Black Champion The leading well-tested ductive. Excellent quality, strong grower.

Prices above: For 2-year, No. 1 standard varieties, 25c each; $\$ 2.50$ per dozen.

\section{Gooseberries}

Should be planted in good, rich soil and well manured once a year. Evell more rugged and easier to grow than Currants. Do not let bushes grow too thick; the fruit will be larger and more plentiful.

Downing Large; light green; soft, tender, good Downing flavor; extremely vigorous, hardy and prolific. Per each, 30e; doz., \$3.00.

Houghton Most productive. Best payer of all. Fruit excellent ield easily 700 bushels per acre. doz., \$2.75.

\section{Buffalo Berries}

Buffalo Berry Silver gray foliage quite like Buffalo Berry the Russian olive in appearance. A native of the Missouri River country, hardy and most prolific bearer, fruit resembles the currant, a beautiful red color, ripens in July. 2 to 4 feet, $40 \mathrm{c}$ each; 5 to $7 \mathrm{ft.,} \$ 1.00$ each.
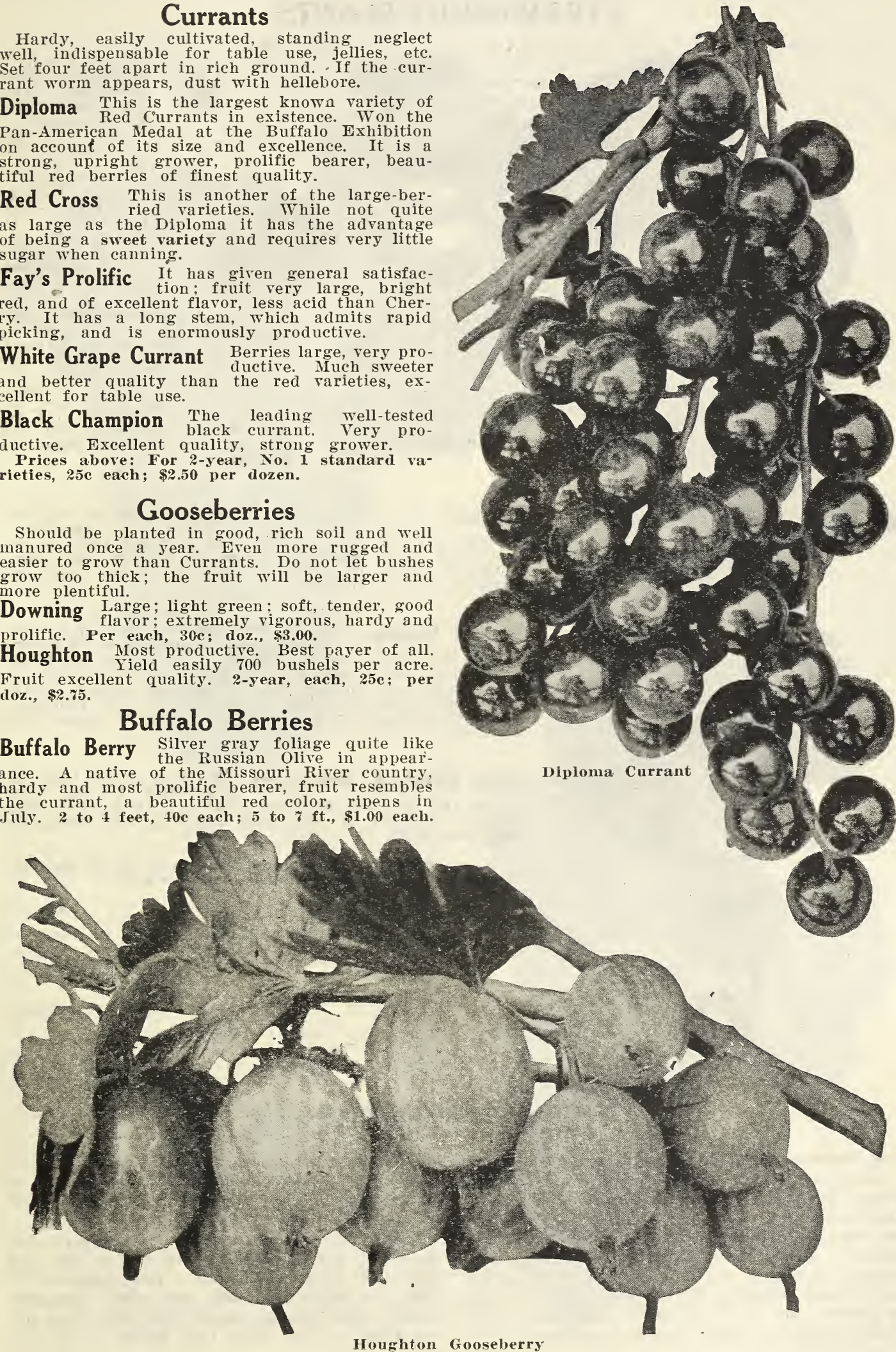

Houghton Gooseberry 


\section{STRAWBERRY PLANTS}

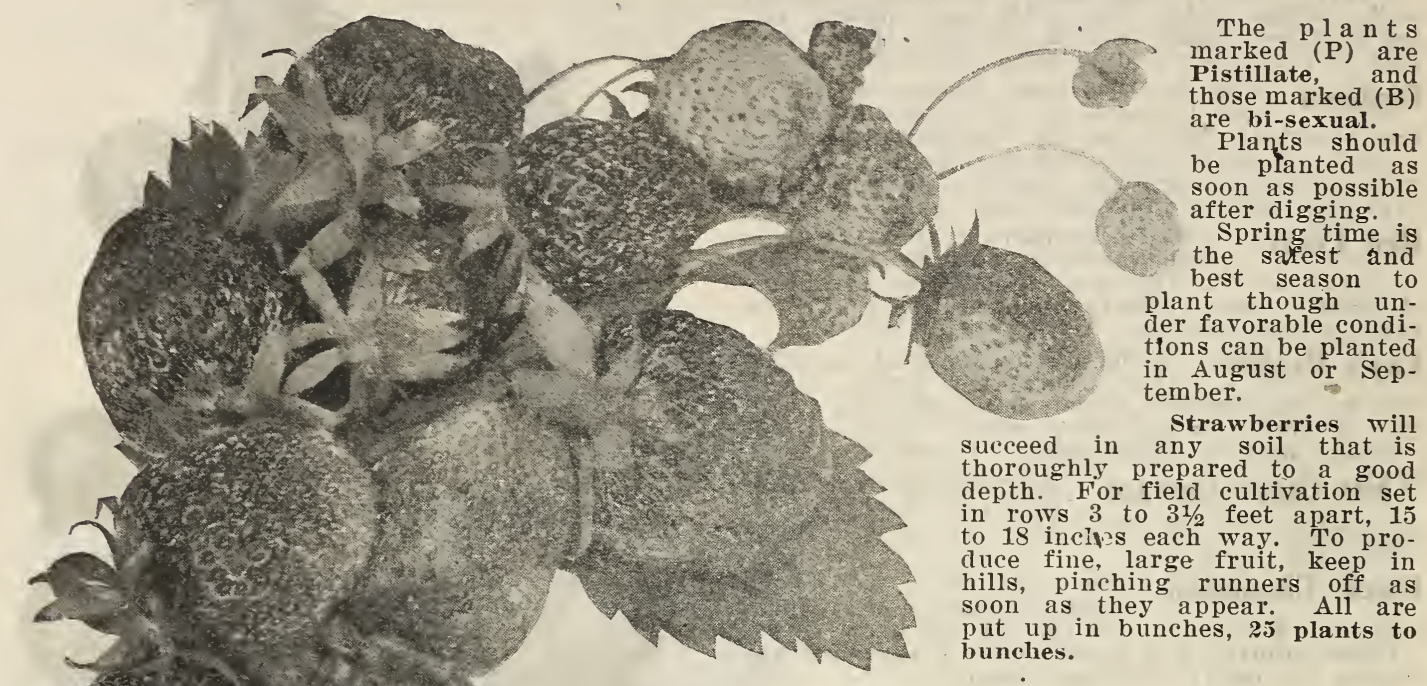

The plants Pistillate, and those marked (B) re bi-sexual. nts should ted as n as possible ter digging.

Spring time is

satest and lant though uner favorable condisan be planted August or Sepember.

Strawberries will succeed in any soil that is thoroughly prepared to a good inth frer field cultivation set to 18 incliss each way. To produce fine, large fruit, keep in hills, pinching runners off as soon as they appear. All are put up

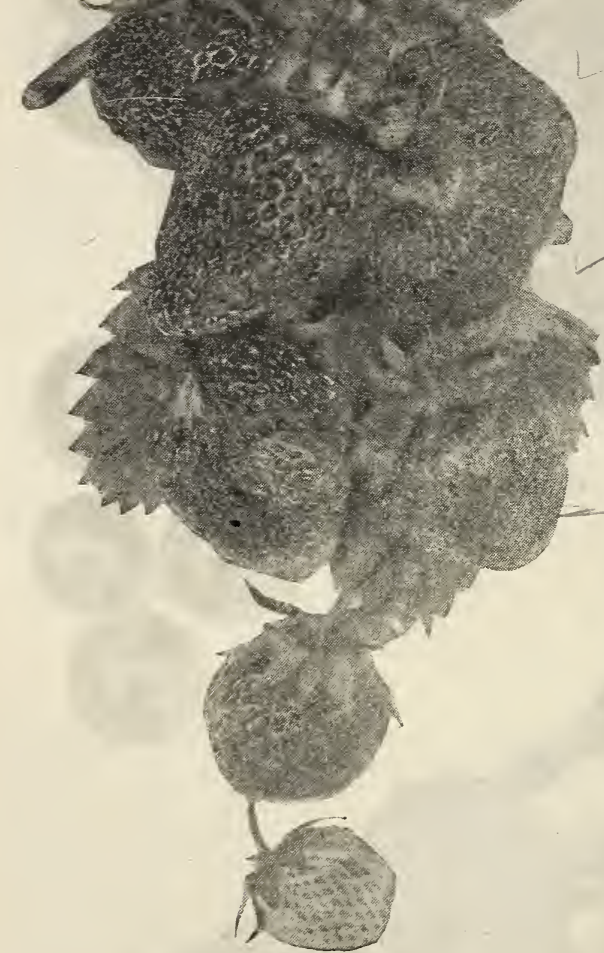

Warfield (P). Early. One of the most popular varieties of strawberries grown; large, top shaped berry, with a glossy red exterior that does not fade or become dull after picking; exceedingly juicy, just tart enough to make it delicious. Plant with two rows of Warfields one of Dunlaps.

Senator. Dunlap (B). Perfect blossom. Medium to late. to One of the most popular varieties known Dorld. Dunlap is a large, handsome fruit, rich, dark red, with a glossy finish, shaded to deep scarlet on the under side, and prominent, bright yellow seeds that look like gold bronze. The foliage is tall, bright green, upright with a long leaf. Plant with Warfield.

Early Elizabeth Strawberry Ten days earlier than the hardy and prolific: excellent quality. As a new, early rariety of berry it surpasses anything that has ever been produced.

Prices of Strawberry Plants, June bearing, 25 for 50c; per hundred, $\$ 1.00$; per $500, \$ 4.50 ; 1,000$ for $\$ 7.50$.

\section{Everbearing Strawberries}

The Everbearing Strawberries Have Made Good There can be no possible doubt any longer about the everbearing strawberries. They have made good and then some. They have proved the past four seasons that they will bear all summer, earlier than the others and until the ground freezes in the fall. Ripe berries, green berries and blossoms all the time. And the best of berries, big and red, sweet and juicy. The plant is medium sized; closely resembling Dun- lap; foliage strong and healthy, has a good root system, makes almost as many plants as Dunlap; spring set plants fruit the same year set out.

There are several varieties, the Superb, the Americus, but the Progressive is the best and only one kind we handle. Progressive-color deep red inside and out, quite firm, rich and sweet. Good young plants, per doz., 50c; per $100, \$ 2.00$; per $500, \$ 8.00 ; 1,000, \$ 15.00$. 


\section{GRAPE VINES}

One of the best, healthiest and longest cultivated fruits we. have. Easy to grow in most any kind of soil that is not too wet, even a stony hill brings good results. Yet they are great feeders and pays to manure them well when planting, rich, well-rotted manure mixed in the soll.

INSTRUCTION-Grape vines should be planted so that the first bud next to the stem will come on a level with the surface of the ground. Grape vines have two layers of roots, from 6 to 8 inches apart, and in planting spread the lower layer of roots in their natural position; fill in the earth and press down in the soil firmly, then spread the second layer of roots and fill in the balance of the hole. After planting trim the vines back to two buds.

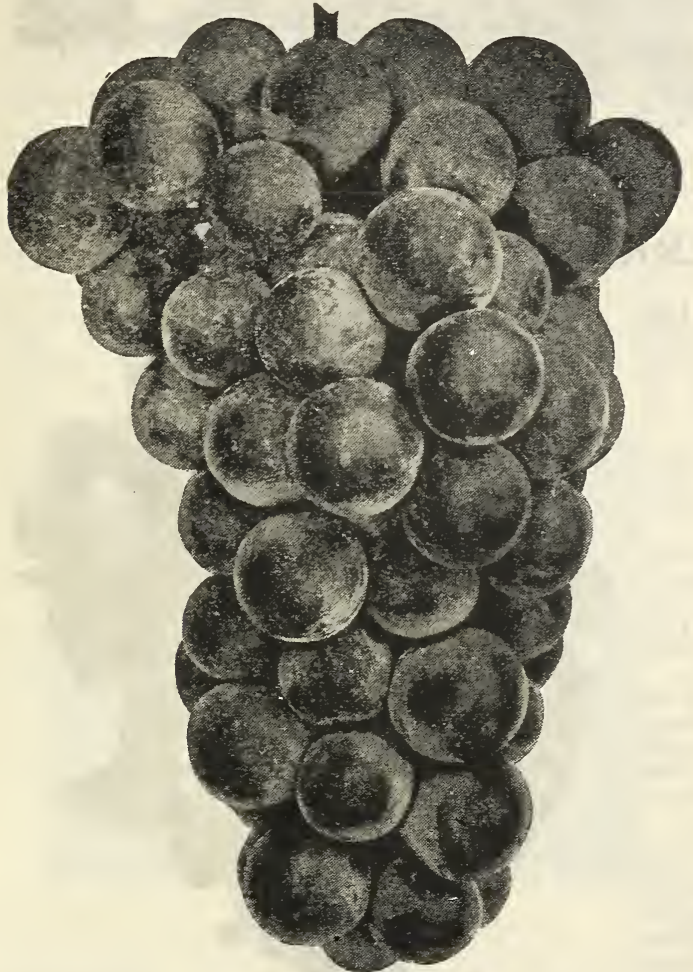

Concord urapes

Concord The most popular grape in America. Concord Bunch large shouldered, compact; berries large, covered with a rich, dark bloom. No. 1 2-year-roots, 25c each; \$2.50 per doz., 25 for $\$ 1.00 ; \$ 15.00$ per 100 .

Niagara White. This is the most valuable large and handsome, compactly filled with large berries. When fully ripe, they are a pale yellow with a thin white bloom. Price: 2 -year-old roots, $35 \mathrm{c}$ each, 4 for $\$ 1.00$.

Campbell's Early Black. A new variety of very hardy, foliage perfectly healthy, very early and abundant bearer. The berries are large, nearly round; dark blué. Price: No. 1 2-yearold star stock, each, 35c; doz., \$4.00.

Clinton. Black Bunches and berries small and auite and compact. Berries juicy and quite acid. A good grape for dark red wine. Vine vigorous grower, productive and hardy. 2-year-old roots, 40 each; $\$ 4.00$ per doz.

Moore's Early Black with heavy blue bloom. Bunches of medium size, rarely shouldered. Berries large, round, of excellent quality; desirable for market on account of its earliness. Price: 2-year-old star stock, 35c each; $\$ 3.50$ per doz.

Agawam Large red grape of rich, sweet, aroA matic flavor. A vigorous, hardy vine. each; $\$ 3.00$ per doz.

\section{Bachus Grape}

Bachus Grape... A new wine grape of powerful growth which originated in northern New York. Absolutely hardy and as strong a viner as the Beta with somewhat better quality fruit but especially a wine grape and one of the easiest grapes to start to grow that we have ever planted. It is a seedling of the Clinton, very productive, free from mildew, adapted to a variety of soils, ripens later than the Beta. Fruit rather tart but if left on the vines until extra ripe, makes an excellent table grape. Per each, 50c; 1 for $\$ 1.75$; per doz., $\$ 5.00$.

\section{Beta Grape}

This is the greatest of all the arbor grapes, a cross with the cultivated black variety and the common wild grape. Vines in great profusion. Unpruned, it runs in every direction, as one man says: "Over the woodshed and down the alley fence in its mad flight to cover everything unsightly in sight." Fruit is medium in size: black in color, rather acid in taste, a splendid wine maker. Bears in great abundance, always bearing every season and is absolutely as hardy as its wild parent. Needs no protection. Price: 2 year-old No. 1, star stock, $40 \mathrm{c}$ each; $\$ 4.50$ per doz. See picture outside back cover.

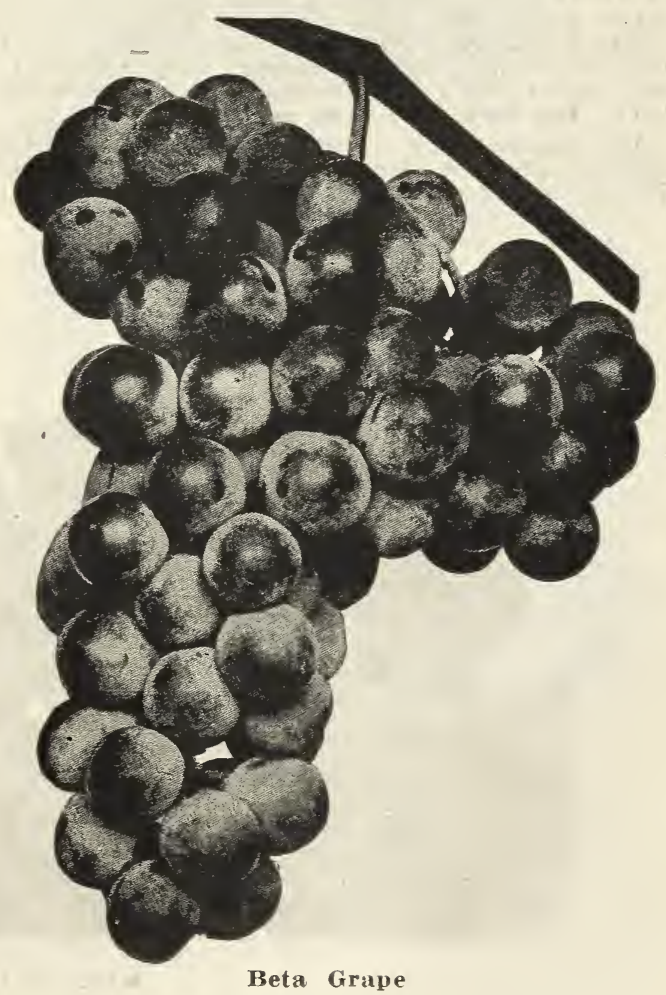




\section{BLACKBERRIES}

Snyder One of the best. Berries juicy tive. Per doz., \%5c.

Ancient Briton Another hardy rariety. der. Strong roots, 10 e each; 75e per doz., per $100, \$ 6.00$.

Bartel's Dewberry Is hardier than any dry or cold climate-a grand delicious fruit. Each, 10c; doz., 75e; per 100, \$6.00.

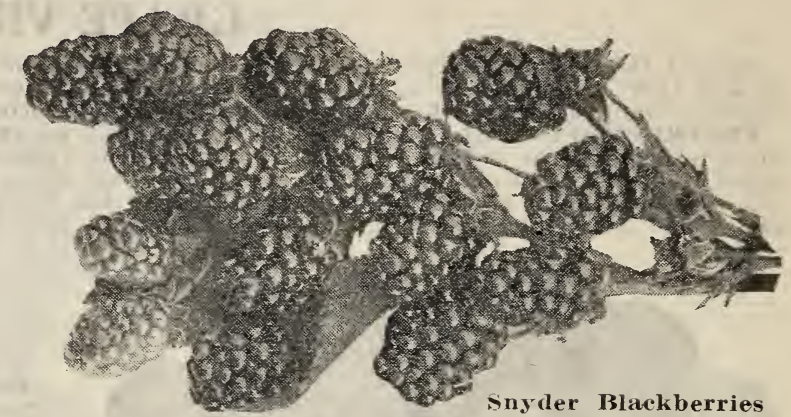

\section{RASPBERRIES}

King of Cliff Black Cap $\begin{aligned} & \text { (Everbearing Black } \\ & \text { Raspberry). Actually bears }\end{aligned}$ continuously from June 1st until killed by trost in the fall. The canes are literally loaded with fruit in all stages from bloom to ripe fruit. Has no equal as an everbearing rariety. Price: 10c each; doz., \$1.00.

Cumberland Largest of all Black Caps; healthy, branched canes that produce immense crops. Per doz., 75e; per 100, \$5.00.

Sunbeam Originated by Professor Hansen of BrookSunbeam ings Agricultural College. It is a powerful grower with very heary foliage and being of Dakota origin it is one of the hardiest red raspberries grown. Quantity of the fruit very fair, medium size and very desirable. Price each, 10c; per doz., \%̃c.

St. Regis Everbearing Red Raspberries for four you when months! That is what bearing variety. A brilliant crimson color; the first raspberry to give ripe fruit and bears without intermission until late October. 10e each; 75c per doz.

Herbert In hardiness it easily takes first place, standing a lower temperature than any other kind. The cane is very strong and vigorous, slightly prickly, leaves large and healthy. Fruit bright red, somewhat oblong, larger than Cuthbert, flavor very sweet and juicy. Season 5 to 6 days before Cuthbert. Per each, 10c; $\$ 1.00$ per doz.

We handle other varieties of both Black Caps and Red Raspberries, standard sorts, which we quote at $75 \mathrm{c}$ per dozen; $\$ 5.00$ per hundred.

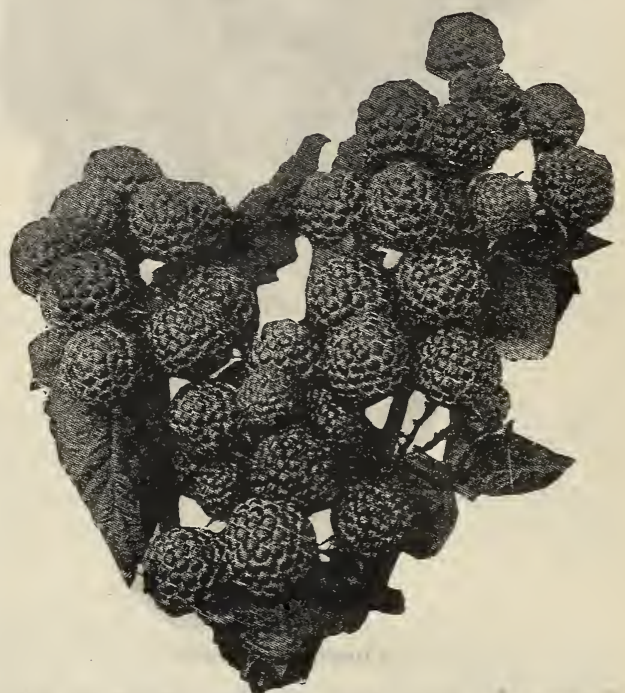

St. Regis Red Raspberries

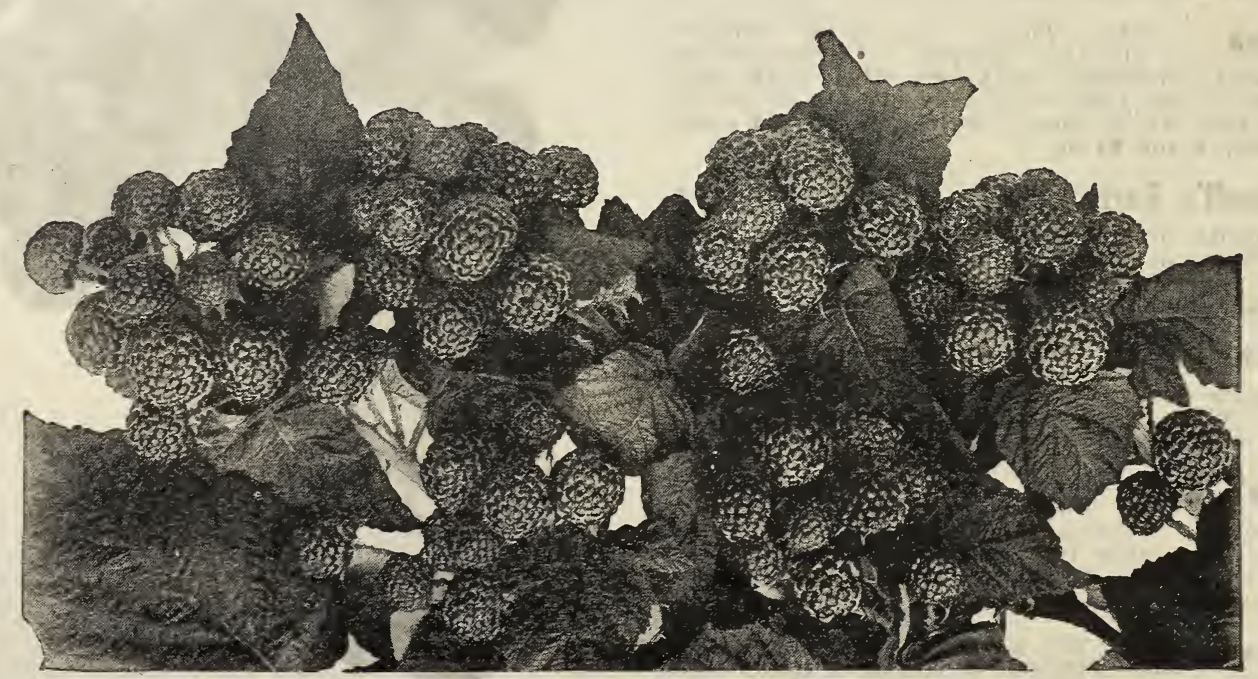

King of Cliff Raspberries. 


\section{ORNAMENTAL FLOWERING SHRUBS}

Nothing adds more to the beauty of a place than to have the sides and background well filled with groups of shrubbery. Whether you have a lawn of many acres, or an humble dooryard, we recommend this class of plants as indispensable to the real beauty of your home.

Almond Double Flowering Pink. One of the ed down with double pink flowers which attract attention. 2 to 3 feet, y5c each.

Almond Double Flowering White... Like above 3 feet, \%5c each.

Dogwood (Quarnus Siberica): A very hardy, dark red bark, making an effective and showy winter display among other shrubs with handsome white flowers in early summer which are distinctly dainty. Per each, 3 to 4 ft., 50c. Large 5 -yr. old clumps, 4 to 6 ft., $\$ 2.50$ each.

Hydrangea Arborescens Everblooming. Someblooming snowball. This new American variety begins blooming in June and continues all season. Very easy of culture and hardy. Blooms best if flowers are clipped before ripening. to 3 feet, each, 75c; 10 for $\$ 6.50$.

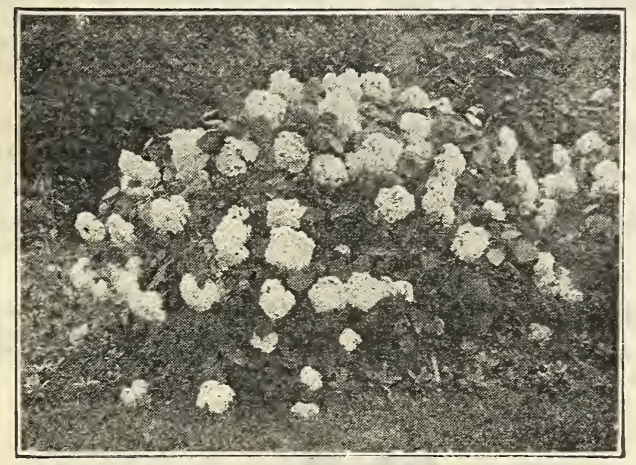

Hydrangea Arborescens

Hydrangea (Pāniculata Grandiflora). Large, fine shrub, growing from 4 to 6 feet high. Flowers white, in large pyramidal panicles, produced in August and September. Each, 2 to 3 feet, 75c; tree form, 3 to 4 feet, $\$ 1.50$ each.

High Bush Cranberry This plant has a handa shiny green color, turning to a rich, coppery tint as the season advances. Flowers are white and conspicuous. The berries are a brilliant scarlet and remain on nearly all winter. Per each, 3 to 4 ft., $75 \mathrm{c}$; large clumps, 5 to 6 ft., 5-year-old, \$2.50 each.

Elder, Golden (Sabucus Aurea) A variety Grows to a height of about 8 feet and is useful for contrast effect. The berries are edible. Should have full sun to give best effect; can be pruned into a neat, compact little bush. 3 to $4 \mathrm{ft}$., 50c each.

Crab (Bechtel's Flowering). Makes a medium Crab sized tree; perfectly hardy, succeeds well in all soils. When in bloom appears to be covered with delicate pink, perfectly double small roses of delicious fragrance. Price: 3 to $4 \mathrm{ft.}$ each, $\$ 1.00$.

Forsythia, Suspensa (Golden Bell). These up the lawn with masses of yellow, very early. in spring before the leaves appear. 2 to 3 ft., 50c each.

Flowering Currants Hardy, bushy shrubs, prized on account of their early spring flowers bright berries and bark; and pretty, richly coloring foliage. Price: 2 to $3 \mathrm{ft}$., 50c each.
Honeysuckle (Red Tartarian, bush form). Grows to a height of 8 feet with upright, somewhat spreading branches and bright green foliage. The flowers are borne freely in May and June, are of a bright pink color. 3 to 4 feet, select, each, 50c; large clump, 5-yearold, \$2.00.

Prunus Triloba (Double Flowering Plum). A Blooms in May. Flowers double delicate pink which are thickly set on long slender branches. Per each, 3 to 4 ft., 75c.

Rhodotyphus (Kerrioides). A distinct decorative shrub. Foliage very large white pendulous flowers in spring followed with black berries that last through the winter. Per eacli, 2 ft. size, 35c. Large clumps, 5 to 6 years old, 3 ft., $\$ 2.00$ each.

Syringa Philadelphus (Coronorious). (Mock strongest-growing varietiorange). Is one of the flowers. Price: 3 to 4 ft., 50c each; large 5-yr. clumps, \$2.50 each.

Syringa Lemoine (Mock Orange). Flowers of double, very variety are large, semihabit and will not get over four feet high. 2 ft., each, 50c.

Syringa, Golden Leaved A handsome dwarf variety with goldenor the entire season; for pleasing effects. Never over 3 feet high. 2 ft., 60c each.

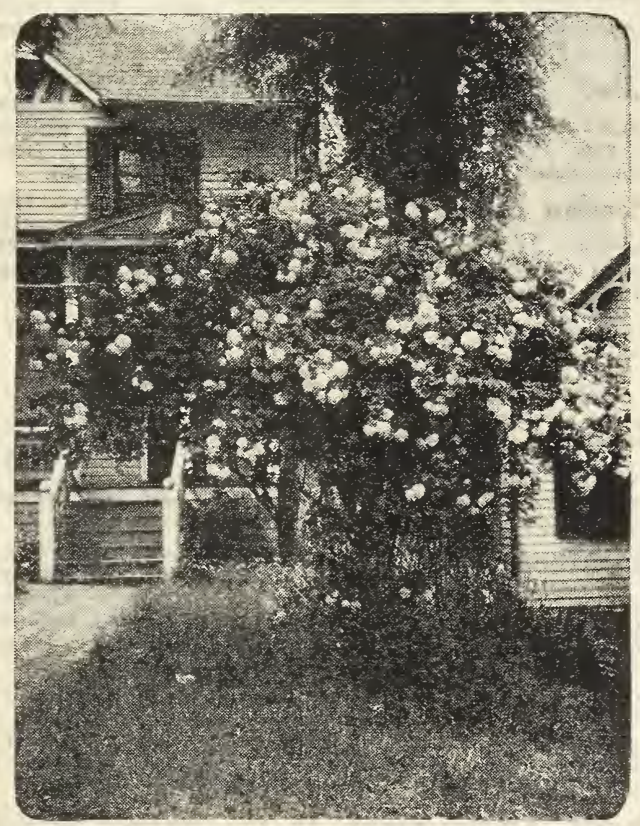

Snowball (Virburnum Opulus Flora Pena) gardens. It grows into a magnificent high bush with upright branches and handsome foliage. It forms one of the most impressive sights of early summer, when its pure white four-petaled. flowers, borne in showy balls are in bloom. Hardy everywhere. 3 to $4 \mathrm{ft}$., 50c each. 


\section{Spirea Van Houttei}

(Bridal Wreath). We can say positively this shrub is the most attractive lawn shrub known. Has white flowers, astonishingly profuse in bloom ing: very fine for cemeteries, 3 to $4 \mathrm{ft}$., 500 each; large 5-year-old clumps, \$2.00.

Spirea Aurea A beautiful variety with golden ers in June. Per each, 3 to 4 ft., 75c; large 5-yr.-old clumps, $\$ 2.50$ each.

Spirea (Anthony Waterer. The grand ornamental hedge shrub; grows about $21 /$ flowers from June until frost. Price: 18 to 24 inches, each, 60c; large 5-yr. clumps, \$1.25.

Spirea Billardi Rich pink colored flowers in summer. Very pretty and showy and splendid for cut flowers. Grows 6 feet high. Price: 2 to 3 feet, 50c each.

Weigelia (Eva Rathke). The finest Weigelia in cultivation: flowering continuously throughout the summer and autumn; of rich ruby carmine. 50c each.

\section{Lilacs}

Do you love the lilac? If so we have something rare and beautiful.

Mme. Casmir Perier The finest double white Mme. Casmir Perier lilac yet introduced. The individual flowers as well as the truss are of immense size, deliciously scented; very fragrant. Price: 3 to 4 feet, $\$ 1.00$ each; tree form, 3 to 4 feet, $\$ 1.50$. Michael Buchner Dwarf variety. Very double ender lilac. Very effective among other taller shrubs as a border feature. ..Each, 2 to 3 feet, 75c. Souvenir de Ludwig Spaeth A choice variety cles of single flowers; dark, purplish blue. Price: 3 to $4 \mathrm{ft}$., each, $\$ 1.00$; tree form, 3 to $4 \mathrm{ft}$., $\$ 1.50$.

Lilac Common Purple or White. The oldfashioned lilac, which grows into a very high bush, with bright green, heart shaped leaves. In May covered with light purple flowers. Each, 3 to $4 \mathrm{ft}$., 75c; tree form, \$1.25.

Persian Lilac Blooms a good deal more than leaves. Does not sprout as much from the roots. Persian white, 3 to $4 \mathrm{ft}$., $\$ 1.00$; tree form, \$1.25; Persian purple, 3 to $4 \mathrm{ft}$., $75 \mathrm{c}$

\section{HEDGE SHRUBS}

\section{Barberry Thunbergi of dwarf graceful hab-} ing to beautiful red early in fall. 18 to 2 inch, per each, 50c; doz., \$5.00; per 100, $\$ 35.00$; large 5-yr.-old clump, $\$ 1.00$ each.

Buckthorn (Rhamnus Catharticus). A dense twiggy bush, with dark foliage, re lieved by masses of attractive white flowers in June and July. Most ornamental of all hedge plants. Makes a good prunable hedge. Price: 18 to 24-inch size, $\$ 7.50$ per 100 .

Russian Olive Makes a medium sized hedge; very hardy and beautiful. Foliage growth is silvery white. The most popular hedge plant of the North. Price, 18 to 24 inch, per $25, \$ 2.00 ; 50, \$ 3.50$; per 100,\$6.50.

Privet, Amoor River Is of vigorous growth, foliage, keeping its color. Price: 18 to 24 inch. 2 to 4 cones, per 160, $\$ 12.50$. Polish Privet. 18 to 24 inch, same price.

Japanese Quince (Red). Cydonia. One of the Japanese Quince earliest shrubs to bloom, the flowers appearing before the leaves are fully developed, the brilliant scarlet flowers glaming like red hot coals. Make beautiful informal or clipped hedge. Very hardy and easily transplanted. 12 to 18 inch size, \$12.50 per 100 .

\section{CLIMBING VINES}

Ampelopsis (Engelmanni). This is one that face, covering it closely with over-lapping foliago. 2-year, 35c.

Ampelopsis (Veitchii). Boston Ivy. It is a object, as it splendid plant for covering any clings perfectly to the smoothest surfaces. Price: 50e each.

Clematis (New). Sweet Scented Paniculata. Flowers pure white in large clusters. Bright green foliage and fragrant flowers. ..Price: 2 -year roots, 50c each.

Clematis Jackmanii. A beautiful, hardy, climbclusters of splendid purple flowers. Price: roots, $75 \mathrm{c}$ each.

Cinnamon Vine Well known Tardy climber quick grower, with beautifu glossy heart-shaped leares and sweet-scented flowers. Vines will run 25 to 40 feet in a season. Large roots, each, 10c; doz., \$1.00.

Dutchman's Pjpe Sipho. A plant of climbing with magnificent light green foliage, growth, pipe-shaped, yellowish brown flowers. Price: $\$ 1.00$ each.

Honeysuckle Scarlet Trumpet. Blossoms freely entire season; bright red

Honeysuckle Hall's Japan. The finest climber, trumpet shaped flowers, sweet scented; extremely hardy. 35c each.

Maderia Vine One of the best and most popular climbers for foliage effect. Large bulbs, 10c each, 75c per doz.; Medium size, 5c each, 50c per doz.

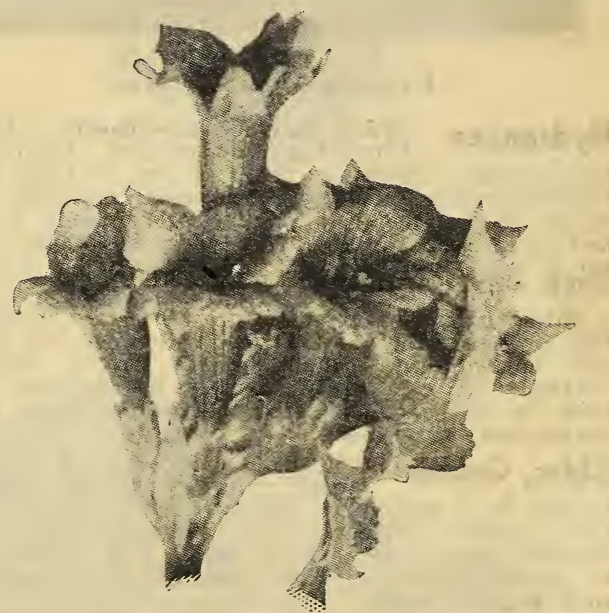

Trumpet Vine Flower

Trumpet Vine Bignonia Radicans. Dark red orange throat, free blooming. Very places, stumps, or wherever a Uroful for cov

Wisteria Purple flowering. Rapid grower. Flowers pale blue borne in long Price: 75c each.

Wild Grape Vine Besides being fruit-bearing hardy. Cultivated vines. Price: 35 c each. 


\section{NATIVE SHADE TREES}

Below we give a list of shade trees that are hardy and can endure the dry weather of the West and the frigid winters of the Northwest.

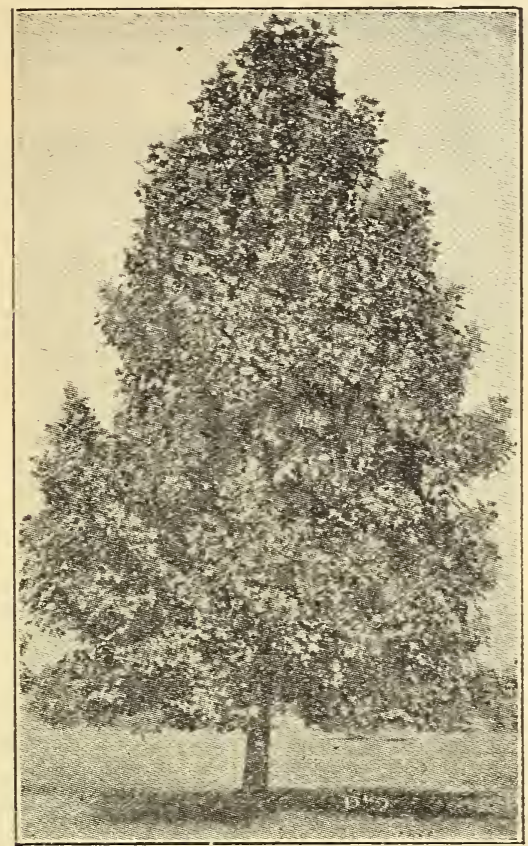

Carolina Poplar

Special Price on any and all varieties shade trees in quantity.

Poplar, Carolina A very rapid-growing tree but has a larger leaf, thicker and more spreading top. 8 to 10 foot, roc each; $11 / 4$ to $11 / 2$ inch caliper, $\$ 1.50 ; 11 / 2$ to 2 inch caliper, $\$ 2.00$.

Bolleana Poplar A tall columnar tree of picaspect. A rery rapid growing and hardy tree, long lired. 8 to 10 foot, $\$ 1.75$ each; 5 for $\$ 7.50$.

Volga Poplar A Russian variety, hardy and umnar type, like the Lombardy, but more durable. 8 to $10 \mathrm{ft}$., $\$ 1.00$ each.

Poplar, Silver-Leaved Rapid growth and wide form. Leaves glossy silvery green abore and white underneath. Very hardy and a splendid shade tree that will grow anywhere. 8 to 10 ft., $\$ 1.25$ each; 5 for $\$ 6.00$.

Maple, Soft or White A native tree. A very med to keep down suckers and avoid forks. 8 to $10 \mathrm{ft}$., $\$ 1.00$ each; $11 / 2$ to 2 inch caliper, $\$ 2.00$ each. Norway Maple A large and handsome tree of compact growth; deep green 8 to $10 \mathrm{ft}$. size, $\$ 2.50$ each.

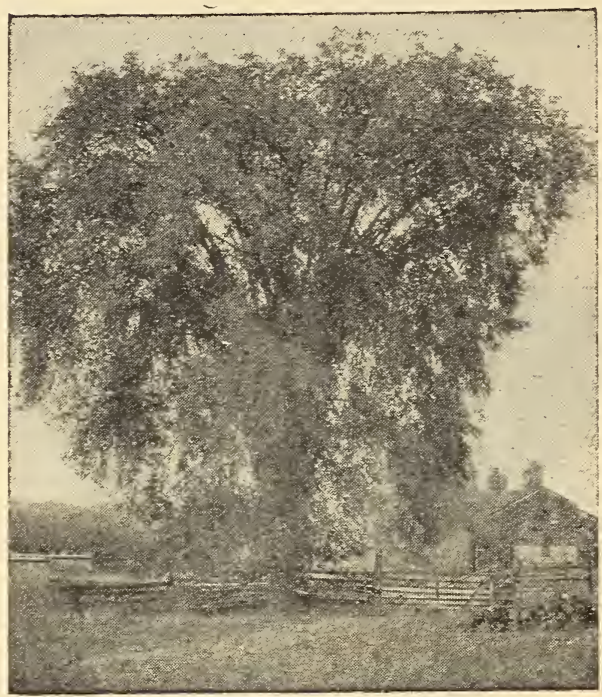

The Stately American Elm

Elm Native White American. A native of South Elm Dakota and the entire Northwest. One $11 / 2$ to 2 incli caliper, $\$ 3.00$ each.

Sycamore A lofty, wide-spreading tree, heartShaped leaves. Makes a fine street tree. 8 to $10 \mathrm{ft.}$. $\$ 1.25$ each.

Hackberry A very desirable street tree of age. 8 to $10 \mathrm{ft} ., \$ 1.50$ each.

Mountain Ash (European). A fine hardy tree; $8 \mathrm{ft} ., \$ 1.00$ each.

Birch (White Bark). A graceful tree with 6 to $8 \mathrm{ft} ., \$ 1.50$ each.

Horse Chestnut (Castenea). White flowering. Horse Chestnut A fine large tree of compact outline, dense dark green foliage. In June corered with white flowers. 5 to $8 \mathrm{ft}$., $\$ 1.75$ each.

Sugar Maple (Acer Saccharum). A popular The foliage is large and handsome and of rich, pleasing green. 8 to $10 \mathrm{ft}$., $\$ 2.00$ each.

Black Walnut This is a common and stateand spreading fy forest tree. Has an open to $8 \mathrm{ft} ., \$ 1.25$ each.

Linden A handsome lawn or shade tree. The Linden blossom is very fragrant and sweet. Price: 8 to $10 \mathrm{ft}$., $\$ 2.25$ each.

\section{Weeping Ornamental Deciduous Trees}

Birch Cut-Leaf Weeping. The most erect and finely cut foliage. Price: 6 to $8 \mathrm{ft}$., $\$ 3.00$ each. Mulberry Tea's Weeping. The most graceistence. Price: 2-year heads, $\$ 3.00$ each.

Babylonian Weeping Willow Napoleon's Willow Babylonian Weeping Wix). A wellous or weeping habit. Price: 5 to $6 \mathrm{ft}$., $75 \mathrm{c}$ each.
Weeping Elm Camperdown. Its vigorous habit, overlap so regularly that a compact, rooflike head is formed. Leaves are large and rich, glossy dark green. Price: 2-year heads, \$3.00.

Mountain Ash (European Weeping). Grafted on tall stems this tree spreads green tent of shade, making it a distinct and beautiful ornament to the lawn. Price: 2-year heads, \$2.50 each. 


\section{ROSES}

Our Rose Department Is a Dream

We handle nothing but the very hardiest varieties and the very finest bloomers. Many varieties are too tender for the Northwest. Hothouse roses a re worthless for outdoor planting-ours are field grown, are more easily transplanted, and hardier. Before planting roses cut them back severely. Our stocks of roses are all 2-year No. 1 powerful roots, and some kinds 3-year Star Clumps.

Mildew. Use Bordeaux Mixture as long as the disease continues. For Slugs, use Hellebore or Arsenic till destroyed. Lice. Use Kerosene Emulsion, apply until destroyed.

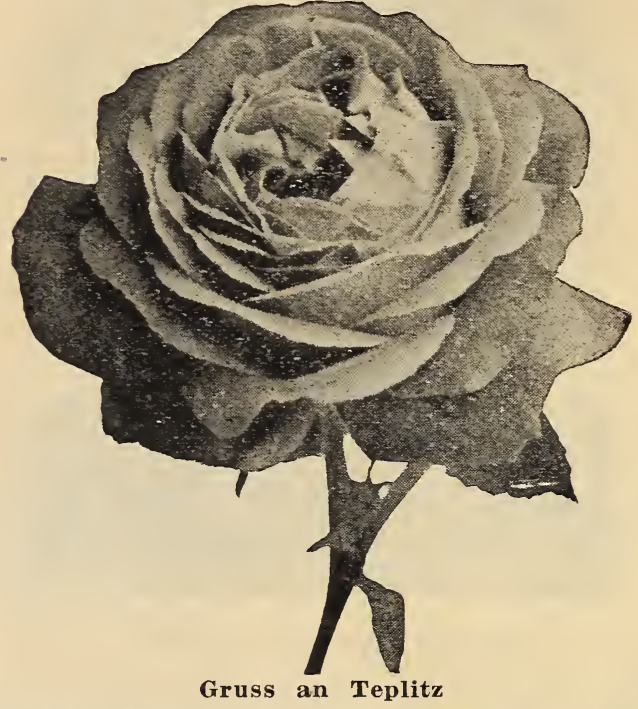

Gruss an Teplitz One of the brightest colored opened, it is a dark, rich crimson, changing to a bright scarlet. Blooms continually; flowers good size and delightfully fragrant. 2-year No. 1 , 75 c each.

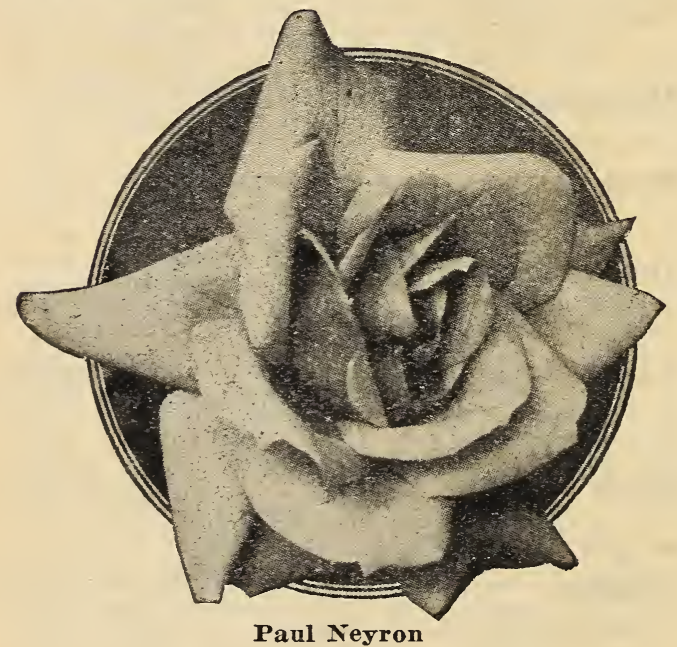

(World's Most Glorious Pink)

Paul Neyron The largest rose in cultivation, sometimes called the Paeony Rose. Color bright, fresh, cerise pink. Flowers are very double and full, delightfully fragrant. The plant makes a strong, healthy growth and has clear, glossy foliage. Blooms almost without intermission from June until late October. Per each, 2-year No. 1, 75c.

American Beauty The world famous rose. sitely shaded. A uich, rosy-crimson, exquiA universal favorite. Not hardy. Price: 2-year No. 1, 75e each.

\section{Hardy Perpetual Roses}

These are hybrids or crosses between June and Monthly roses, partaking of the hardiness of one parent and the perpetual blooming habit of the other.

General Jacqueminot This might be called the rose for the mil

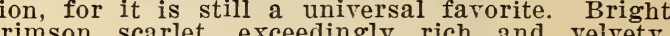
Price: 2-year No. 1, 75c each.

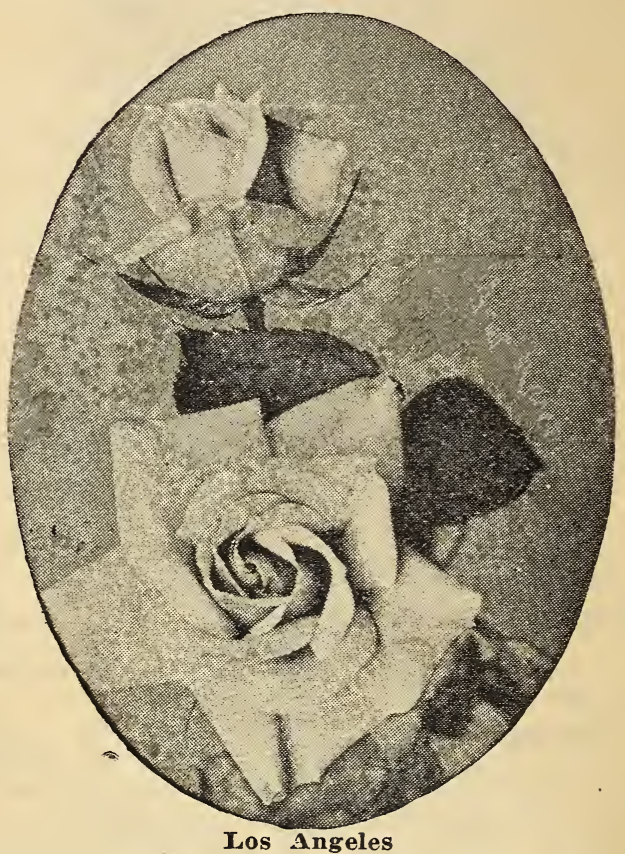

Los Angeles This is one of the grandest allerer put on the market. The stems arican origin as American Beauty; the flowers are large as Paul Neyron; its freedom and continuance of bloom are remarkable: its color a "flame pink, toned with coral and shaded with translucent gold at the base of the petale" er $<n$ mnh.

\section{Frau Karl Druschki}

White American Beauty. (Lambert, 1900). This grand rose has become renowned as the very highest type of its class and the best snow-white rose ever introduced. It is an extraordinary grower, and has the vigor and hardiness of an oak. 2-year No. 1, $\$ 1.00$ each.

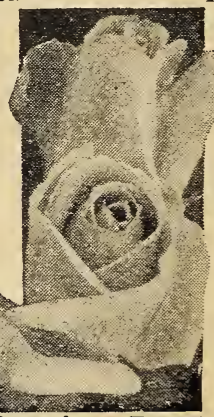

Druschki, White American Beauty

The Hoosier Beauty This rose is a glowing with dark shadings, a perpetual bloomer and bids fair to become one of our choicest garden varieties. 2-year No. 1 stock, 75c each. 


\section{Ramblers and Climbing Roses}

Climbing American Beauty This variety reink to tains the deep or and the same delightful fragrance of the bush American Beauty. 2-year, $60 \mathrm{c}$ each.

Rambler Roses

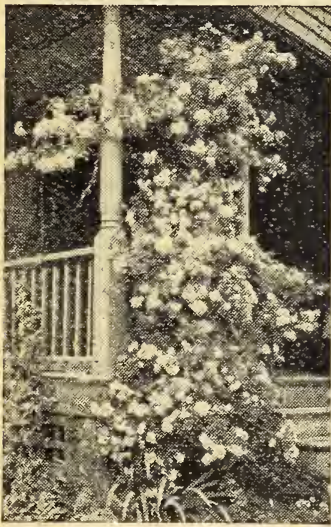

(C. P). This grand old climber hardly needs description. The magnificent trusses of bright crimson flowers are freely produced and admired by everyone. Very hardy and a strong grower. 2-yearold, No. 1 stock, each variety.

Crimson Rambler, 60c. White Rambler, 60c. Yellow Rambler, 60c. Blue Rambler, 60c.

\section{Dorothy Perkins}

The most popular climbing rose of today and hardier than the Ramblers. Most beautiful shell pink and holds a long time without fading. 2-year, 50c each, 3 for \$1.25.

\section{Rugosa Roses}

Rugosa Roses (Ramanas). 'The hardiest rose Thrt in existence. Ideal for the es 3 to 5 feet in height, covered with handsome glossy, green foliage and clusters of beautiful fragrant flowers. Rugosa, single red; Rugosa, single white. 2-year No. 1 field grown, 50c each, 3 for $\$ 1.40 ; 1$ doz., $\$ 5.00$.

Conrad F. Meyer (Hybrid Rugosa). Flowers shaped. Color, deep, bright, vivid, intense, cup with a penetrating fragrance. 2-year No. 1, each 75e.

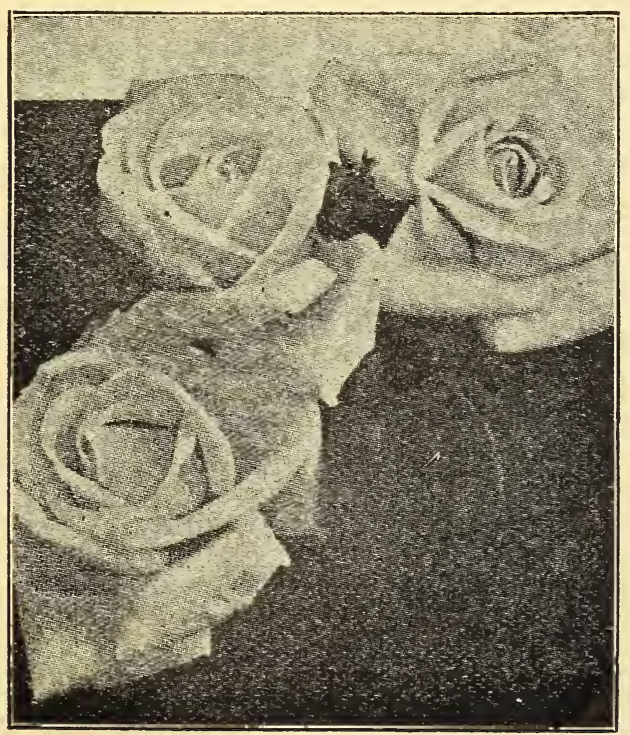

Sir Thomas Lipton

Sir Thomas Lipton (Hybrid Rugosa). The best pure white Rugosa Rose. Strong and vigorous; grows four feet high. Flowers perfectly double, pure snow white, with a penetrating fragrance. Price, 2-year-old No. 1, each, $75 \mathrm{c}$
Excelsa (New). (Red Dorothy). The color is an intense clear crimson, with tips of the petals tinged with scarlet. Grows 10 feet in a season. Flowers are large and double and almost every eye produces a cluster of bright blossoms. 2-year No. 1 stock, 60c each.

White Dorothy A beautiful white flowered cluster Rose, as free and expressive as its pink rival, the Dorothy Perkins. The rines are a sheet of white during their blooming season. 2-year No. 1 stock, 50c each.

American Pillar A single-flowering variety of great beauty which appeals to 4 inches across, of a lovely shade of pink, with a clear white eye and cluster of yellow stamens. 3 year No. 1 stock, $75 \mathrm{c}$ each.

Gardenia (Hardy Marechal Neil). The finest hardy yellow climbing rose yet Deep, rich golden yellow; flowers borne in great profusion on strong, vigorous bushes as hardy as oaks. 3-year Star stock, hardy field grown, each, 75c; 3 for $\$ 2.00$.
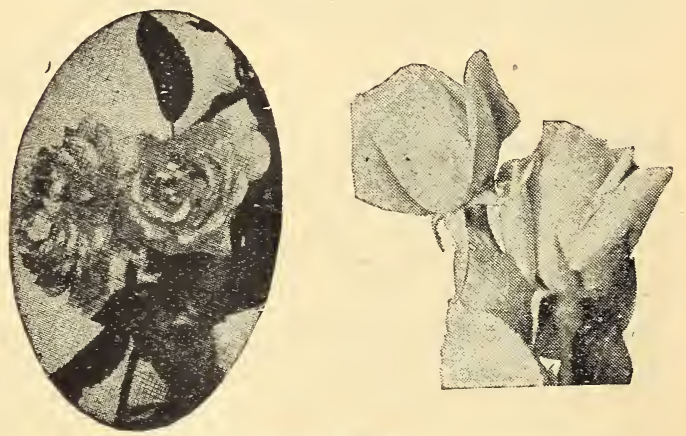

Baby Roses

\section{Dwarf Polyantha Roses}

Baby Rambler The flowers are borne in clusage is dark, glossy and profuse.

Crimson Baby Rambler, 75e each.

Pink Baby Rambler, 75e each.

White Baby Rambler, "5e each.

\section{Cemetery Roses}

Memorial White Rose, Mandy's Triumph. (Wichuraina). This rose makes a beautiful and enduring covering for graves and plots in cemeteries. A very hardy Memorial Rose. It creeps along the ground as closely as Ivy. Flowers are produced in lavish profusion. They are single pure white, with a golden-yellow disc five to six inches in circumference. It is also immensely valuable as a climbing rose, covering arches, fences, etc. 2-year No. 1, each, 50c; 3 for $\$ 1.40$.

\section{Potted Roses}

These are hardy varieties suited for outdoor culture, potted in four and six inch pots, started in the greenhouse and in full foliage, ready to bloom and blooming. Can be planted oudoors, about the 1 st to the 10 th of May. Will continue to bloom all throughout the summer and fall. 4-in Potted Roses, blooming, 75c each. 6-in. Potted Roses, blooming, \$1.50 each. 


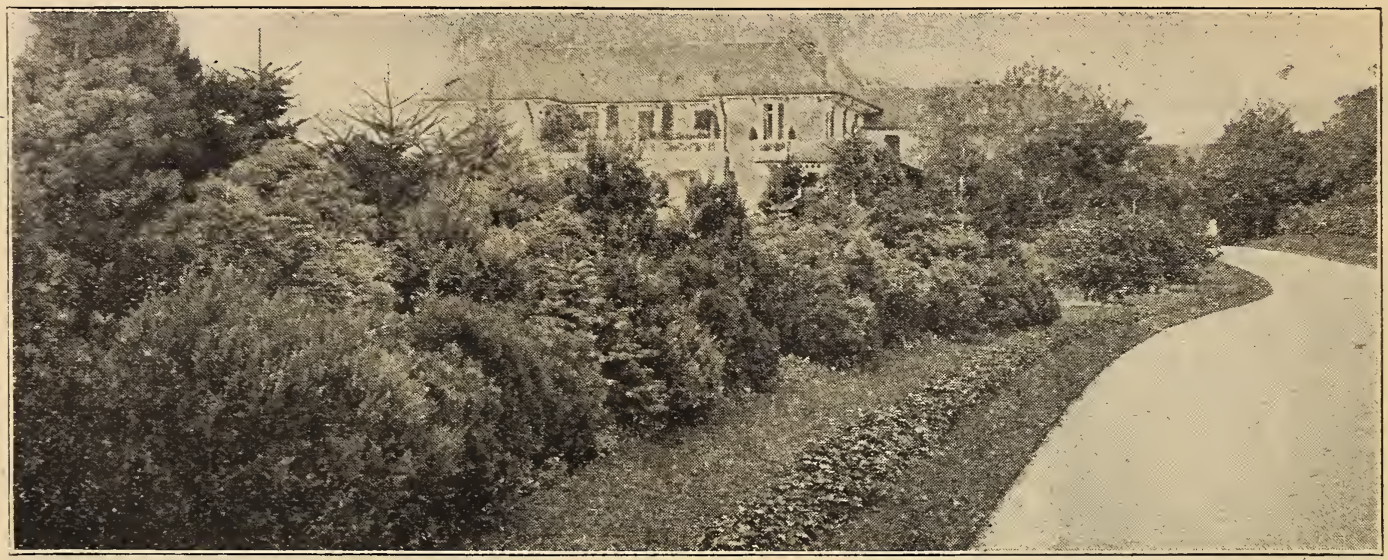

An Evergreen Planting Which Appeals to Our Love of the Home Beautiful

\section{HARDY EVERGREENS}

Evergreens give a cheerful appearance to a home. If properly handled, taken up with ball of earth are as sure to live and grow as deciduous trees. "We list only such varieties as are found to do the best here in this soil and climate. See special prices in large quantities seedlings and transplanted stock given below.

ORNAMENTAL STOCK

Specimen Trees

Red Cedar (Juniper Virginiana). The well ing some in habit and color of foliage. Very attractive in winter when the golden bronze of the young growth contrasts with the dark green foliage of the older growth. 2 to $3 \mathrm{ft} ., \mathbf{B} \& \mathbf{B}$., $\$ 2.00$ each. Pyramidalis form, B \& B., 4 to ft., $\$ 5.00$ each.

Arbor Vitae Pyramidalis. This exceedingly compact and erect of the entire species, being in form almost a counterpart of the Irish Juniper. Foliage a deep green, retaining color remarkably well through the entire season and perfectly hardy. Specimen trees, 2 to $3 \mathrm{ft} ., \mathrm{B}$ \& B., $\$ 3.50$ each; 3 to $31 / 2$ ft., $\$ 5.00$.

Arbor Vitae Globoso. A new variety that is Arbor Vitae very handsome. In shape it is absolutely round, very dense in growth and does not require shearing. It does not grow over 4 or 5 feet tall; foliage is deep, dark green. Each tree dug with ball of earth and roots burlapped. Specimen trees, 1 to $11 / 2 \mathrm{ft}$., B \& B., \$2.50 each; 2 to $3 \mathrm{ft}$., $\$ 4.00$ each .

Mugho Pine (Dwarf). Very distinct, leaves thickly distributed over the branches; does not grow tall but spreads form; very dense. Per each, diameter measure $1 \frac{112}{2}$ feet, $B \&$ B, $\$ 2.00$ each; 2 to $3 \mathrm{ft}$., $\$ 3.50$.

Hemlock Spruce A weeping evergreen. A tive tree with drooping branches, and dark, delicate foliage of green. It makes a fine lawn tree or ornamental hedge. Price: 2 to $3 \mathbf{f t}$., B \& B., \$3.50; pair, $\$ 6.00 ; 3$ to $4 \mathrm{ft.}, \$ 5.50$; pair $\$ 10.00$.

\section{Pines for Shelterbelts and Groves}

White Pine The White Pine is the most known raluable shelter belt evergreen is of the easiest transplanted of dived and does well everywhere. Makes perfect windbreaks, shelter breaks or screen. Price: 2 to 3 ft., B \& B., $\$ 1.50$ each.

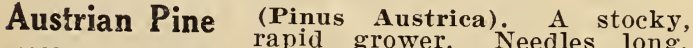
stiff and dark green. Rather handsome and fine formed. A much better and more lasting tree than the Scotch Pine. Price: 2 to 3 ft., B \& B., $\$ 1.50$ each.
Black Hills Spruce (Picea Alba). This has for many generations. It is admirabiy equipped for the IVestern prairies, easily transplanted and altogether it is very desirable for the general planter. Specimen trees, ball dirt burlapped, 2 to $3 \mathrm{ft}$., $\$ 1.60$; pair for $\$ 3.00$.

Norway Spruce A rery beautiful evergreen of It is well large and lofty appearance. will stand pruning for windbreak purposes and Specimen trees, ball and burlapped, 2 to $3 \mathrm{ft}$., $\$ 2.50$ each.

Blue Spruce (Koster Grafted). Other trees able color and form, but here is truly the culmination of Nature's highest effort to produce the beautiful. Specimen trees, 2 to 3 ft., $\$ 7.00$ each; 3 to $4 \mathrm{ft}$., $\$ 8.00$ each.

Colorado Blue Spruce $\begin{gathered}\text { (Picea Pungens). It } \\ \text { is extremely hardy }\end{gathered}$ and endures well the sun and drying winds. The needle is very sharp pointed and varies in color from a delightful green to a deep blue. Specimen trees, select blue, 2 to $3 \mathrm{ft}$., each, $\$ 5.00$; per pair, matched, $\$ 9.00$.

Cemetery Evergreen Trailing Juniper. (J. Sabina). A low, spreading very hardy and suitable for lawns and cemeteries; can be pruned to any desired shape. 2 to $3^{1 / 2} \mathrm{ft}$., diameter, branclies 24 to 36 in., $B \&$ B., $\$ 4.00$ each, $\$ 7.50$ pair.

Scotch Pine Native of Europe, a fine, robust, rapid growing Evergreen. Foliage medium length needles with stout, erect shoots and silvery green foliage. 2 to $3 \mathrm{ft}$., $\mathbf{B} \&$ B., \$1.50 each; Mugho form, $2^{1 / 2}$ ft., $B$ \& $\mathbf{B}$., $\$ 3.00$ each.

Jack Pine (Pinus Banksiana). An unusually rapid grower, making two or three joints each year, where other pines make but one. A rery valuable tree in sandy poor soils where nothing else will succeed. Price: 2 to 3 ft., B \& B., $\$ 2.00$ each. 
Special_Evergreen Seedlings

AND TRANSPLANTED STOCK

Seedlings 'Transpl'd Stock

4 to 6 in. $11 / 2$ to $2 \mathrm{ft}$.

Per 100 Per 10 Per 100

Jack Pine

White Pine

scotch Pine

Norway spruce

Red Cedar

Arbor Vitae

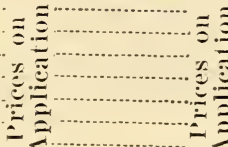

Austrian Pine

Black Hills spruce

\section{Forest Tree Seedlings}

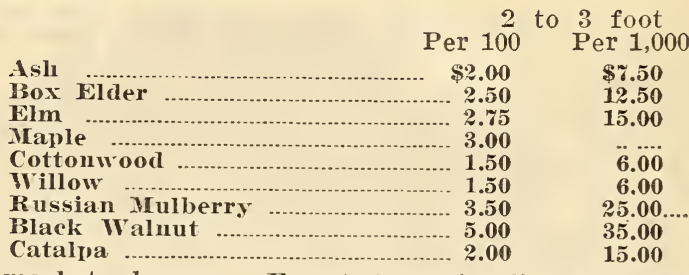

YOTICE-All prices subject to conditions and market changes. Forest trees in fire and ten thousand lots, special prices on application.

\section{INSECTICIDES AND FUNGICIDES}

The control of insects and fungi is imperative in every garden. Plants must be protected from their enemies, if they are to produce most luxuriantly in flower and fruit. There are three kinds of these enemies-fungous diseases or blights, insects which eat the foliage, and insects which suck the sap of the plants.

Dry Lime Sulphur Best remedy for San Jose use early in the season before the foliage puts out on fruit trees and berry bushes; mix one part to ten parts water. Also one of the best summer sprays as an excellent fungicide. When used in summer dilute with twenty to thirty parts water. Prices: 1b. pkg., 40c each.

Arsenate of Lead Dried powder Arsenate of Lead will destroy leaf eating or leaf chewing insects such as the coddling IIoth, Plum Curculio, Canker Worm, Tussock IIotl, Gypsy and Brown Tail Moths, and similar insects that feed on the foliage of fruit trees, shade trees and ornamental shrubbery. It readily mixes with water and stays in suspension almost indefinitely and insures an eren distribution of the poison. Price: 1 lb. pkg., 50c each. Hammond Slugshot Guaranteed to destroy potatoes, tomatoes, egg-plant, also currant worms, cabbage lice, and cabbage worms. I lb. package, 25e; 5 lbs., $\$ 1.00$

Bordeaux Mixture The best fungicide for curing and prerenting black. rot, mildew and blight. Price: lb., 50c.

Paris Green Our Paris Green is absolutely pure and meets the requirements of State and National laws. ${ }^{2}$ Put $u$ p in sift-proot cartons. Prices on application.

Nicotine Sulohate "Black Leaf 40 " is a concentrated solution of nicoweight. It is a contact insecticide. Per oz. bottle, 3ãc.

Tree Tanglefoot A perfect safeguard for trees against the Caterpillar of the Gypsy, Brown Tail and Tussock Moth, and also Canker Worms, Cut Worms, Ants and other creeping insects. Will remain sticky about three months when fully exposed to the weather. A band of one sixteenth of an inch thick cannot be crossed by insects. Works equally as well during a rainstorm as before and after it. Will not dry up and drop off in hot weather. It acts as a trap in catching insects at any temperature between freezing and 110 Fahrenheit. Price: 1 1b. cans, 60e each.

\section{FERTILIZERS}

For the intensive cultivation of plants in the home sarden or crounds. fertilizers play a rery important part. The following fertilizers represent the best for the home garden and the lawn. All prices subject to market changes.

Prices quoted are F. O. B. depot or delivered in city within delirery distance. joc per hundred allowed from these prìces delirered at store door, 316 Pearl St.

Sheep Manure A pure, natural manure that directly in the immediate effect. Plantit promotes a rapid and steady growth until maturity. On lawns well raked in either springtime or fall adds wonderfully to the growth of the grass, $100 \mathrm{lbs}$ to about $2500 \mathrm{sq}$. ft. It makes the richest, safest and best liquid manure. For use in liquid form, $1 \mathrm{lb}$. of the material to 5 gallons of water will make a liquid that

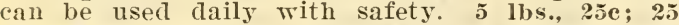
lbs.. \$1.00; 100 lbs., \$3.00; 500 lbs., \$12.00; ton, $\$ 35.00$.

Stim-U-Plant Comes in tablet form and conStim-U-Plant tains highly concentrated plant the growth of flowers, regetables, fruit and the ormamental plants. Full description with each package. Trial size, 10 tablets, 25̃; Medium size, 30 tablets, $5 \mathrm{c}$.

Bone (Fine Ground). For use by the regetable gardener it is superior to anvthing on the market. It has been steamed to soften same and is quick to act. For trees or vines use 2 to 4 lbs. About $5 \mathrm{lbs}$. for 100 square feet for starting a new lawn. Per 1b., 10e; 3 lbs., 25e; 100 lbs., \$4.50.

Peat Humus A decayed vegetable matter Peat Humus which loosens the soil, makes it more pliable, enabling the soil at the same time to retain moisture more effectively, besides adding to the fertility and life producing qualities of the soil for plant life. $100 \mathrm{lbs}$. to $1,000 \mathrm{sq}$

ft. Per 100 lbs., $\$ 2.50$.
Gypsum (Eand Plaster). Calcium sulphate. All regetable crops, as well as most phur in building rarious organic compounds. GIPSUM furnishes this item in an immediately arailable form-sulphate of sulphur. It improves the condition of the soil, making it granular, much as lime does. Agricultural gypsum is a preservative and deodorizer of barnyard, stable and hen-house manure. Holds the ammonia, preserving the nitrogen until it can be applied to the soil. We handle Ben Franklin brand of Gypsum. Apply 400 to 800 lbs. per acre for garden crop: 200 to 400 an acre for field crop. Per 100 lbs., \$2.00; per 500 1bs.. \$8.00.

Acid Phosphate This fertilizer is the most phosphorus. It can be used on any crop that bone meal is used on. It is very soluble and more quickly taken up by the plant life than bone meal. Phosphorus promotes root growth in roung plants and is the active element in the formation of seed or grain. Crops are often matured as much as a week in advance of normal by use of phosphate. Any soils which have been cropped for any great length of time soon become lacking in phosphorus for the best results. Per 100 lbs., \$2.50; 500 lbs., \$12.00.

Nitrate of Soda Not a substitute for other in which to apply nitrogen to the plants. In pulverized form can be used as a top dressing at the rate of $1 \mathrm{lb}$. for 500 square feet, or 100 lbs. per acre when plants are well established. Per, lb. 15e; special prices in quantity. 


\section{POULTRY SUPPLIES}

\section{ALL PRICES ON POULTRY AND ANMML FOODS SUBJECT TO CHANGE}

Our Poultry Foods Are All Foods-No Waste, Always the Same

Starter (For the Little Fellows.) ..Is a complete and properly balanced food for small chicks two days to two weeks old, adapted to their delicate digestive organs 6 1bs., 25c; 50 lbs., \$1.35; 100 lbs., \$2.50.

Eureka This is a food intermediate between the Eureka Starter and the Acme Scratching Food. (For chicks from two weeks to two mouths old). 6 lbs., 25c; 50 lbs., \$1.35; 100 1bs., \$2.50.

Acme (Scratcli Food). We claim it to be the Acme best all-around scratch food offered to the trade. All food and no waste. 6 lbs., 25c; 100 lbs., \$2.25.
ALFALFA MEAL furnishes the green food that is absolutely necessary for winter $\in \mathrm{gg}$ production. 5 lbs., 25c; 100-lb. bags, \$2.75.

CRUSHED OYSTER SHELLS. This is one of the most commonly used articles in poultry yards. Price: 12 lbs., 25c; 100 lbs., \$1.50.

CHARCOAL. Most successful poultry raisers feed this soft food. 3 lbs., 25c; 10 lbs., 60c.

MICA GRIT. Fowls have no teeth, so it is essential that they should have grit. 100 lbs., $\$ 1.50$.

\section{BLATCHFORD'S PRODUCTS}

Calf Meal Milk substitute made in an exclulb. bag, $\$ 1.25$; 50 lbs., $\$ 2.50 ; 100$ lbs., $\$ 4.50$.

Pig Meal Milk substitute made in an exclu1b. bag, $\$ 1.25 ; 50$ lbs., $\$ 2.50 ; 100$ lbs., $\$ 4.50$.

Egg Mash This is a genuine Egg Increases the egg output and keeps the hens in vigorous condition. $25-11$. bag, $\$ 1.25 ; 100$ lbs. for $\$ 4.50$. Milk Mash The ideal food for brine and muscle, excellent for growing chickens. 25-1b. sacks, \$1.50; $\$ 6.00$ per 100 .

\section{Animal Poultry Foods}

Bone (Coarse ground for poulBone try). Rich in Bone Phosphate and Lime. Lb., 10c; 5 lbs., $25 c ; 100$ lbs., \$4.50.

Blood Meal It will make hens months. Lb., 10c; 3 1bs., 25c; 10 lbs., ซ็c.

Meat Meal Is a combination of Neat $\mathrm{meat}$ trimmings$25 \mathrm{c} ; 100$ lbs., \$5.00.

Beef Scraps (Granulated Protein Lb., 10c; 4 lbs., 250 to 65 per cent).

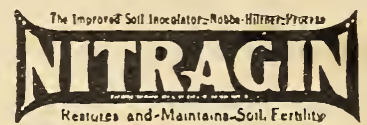

Soil Inoculator

\begin{abstract}
The New Way to Spray
As used with bucket, knapsack, tank or barrel for spraying orchards, gardens, vineyards, whitewashing, disinfecting chicken houses, killing vermin on stock. It throws a spray 25 feet; throws a solid stream 50 to 60 feet high. With two solid brass valves. No leather washers or sockets. No castings to rust. No leaky joints. Nothing to get out of order.
\end{abstract}

\section{Price $\$ 6.00$ Each}

\section{Warranted to Purchaser for Five Years}

\section{Planet Jr. Garden Planters}

Special Cut Price. Subject to change without notice.

No. 4D Planet Jr. Combined Hill and Drill Seeder. As Seeder only, $\$ 14.00$ each.

No. 25 Planet Jr. Combined Hill and Drill Seeder, Double Wheel Hoe, Cultivator and Plow. $\$ 20.00$ each. Weight, packed, $61 \mathrm{lbs}$.

\section{Keystone Berry Boxes}

Be sure to name crop you want to inoculate.

\section{A Great Price Reduction}

to farmers growing Alfalfa, Soy Beans, Clover and other legumes

\section{BUSHEL SIZES instead of ACRE SIZES}

Price: $1-b u$. size, $\$ 1.00$ per can. $1 / 2-b u$. size, 55̃ per can.

This means NITRAGIN will now cust you: $20 \mathrm{c}$ per acre if you sow 12 lbs. seed to the acre. $25 \mathrm{c}$ per acre if you sow $15 \mathrm{lbs}$. seed to the acre. $331-3 \mathrm{c}$ per acre if you sow $20 \mathrm{lbs}$. seed to the acre.

NITRAGIN for field peas is sold in $1 \mathrm{bu}$. and $1 / 2$ bu. sizes. Price per bu. size., $\$ 1.00$ per can. For $1 / 2$ bu. size, 55c per can.

There is also a garden size for peas, beans and sweet peas. Price: 15e per can.

\section{Farmogerm}

All leguminous seeds make a stronger growth and will add more nitrogen to the soil if they are inoculated with Farmogerm. Their cultures are all different. In ordering be sure to state what crop you wish to inoculate.

New reduced prices: 12 acre size, $\$ 9.00 ; 3$ acre size, $\$ 2.50 ; 1$ acre size, $\$ 1.00$.
This box is manufactured from clean chip board, paper waxed on one side, well ventilated, clean, sanitary, easy to set up without breakage and requires no tacks, wire or equipment of any kind for assembling. Can be assembled in the field by the picker. Does not deteriorate, crack, or warp when stored for carrying over. Fits any ordinary crate. Furnished in quart and pint sizes.

Pint sizes: per 100,90c; per 500, \$4.00; per 1,000 $\$ 7.50$. Quart sizes: per $100, \$ 1.00 ;$ per $500, \$ 4.50$; per $1,000, \$ 8.00$.

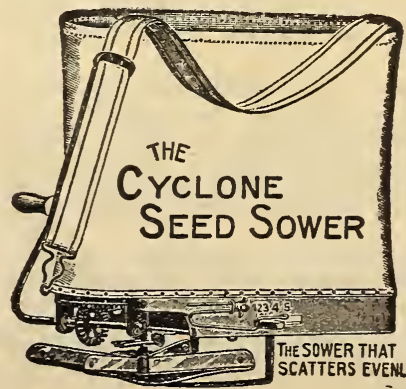

Langs's Hand Weeder

Handiest Tool on Warth Per each, 20c.

\section{Cyclone} Seeders

It is especially designed for distributing evenly all kinds of grain as well as every variety of grass seed. Price: $\$ 1.00$ 


\section{Peonies-World's Greatest Three}

All Perfect in Points Perfection

\section{PEONY CLUMPS}

3-year-old undivided Price Each FESTIVA MAXIMA

EDULIS SUPERBA

FELIX CROUSE

See Page 25 for Full Description
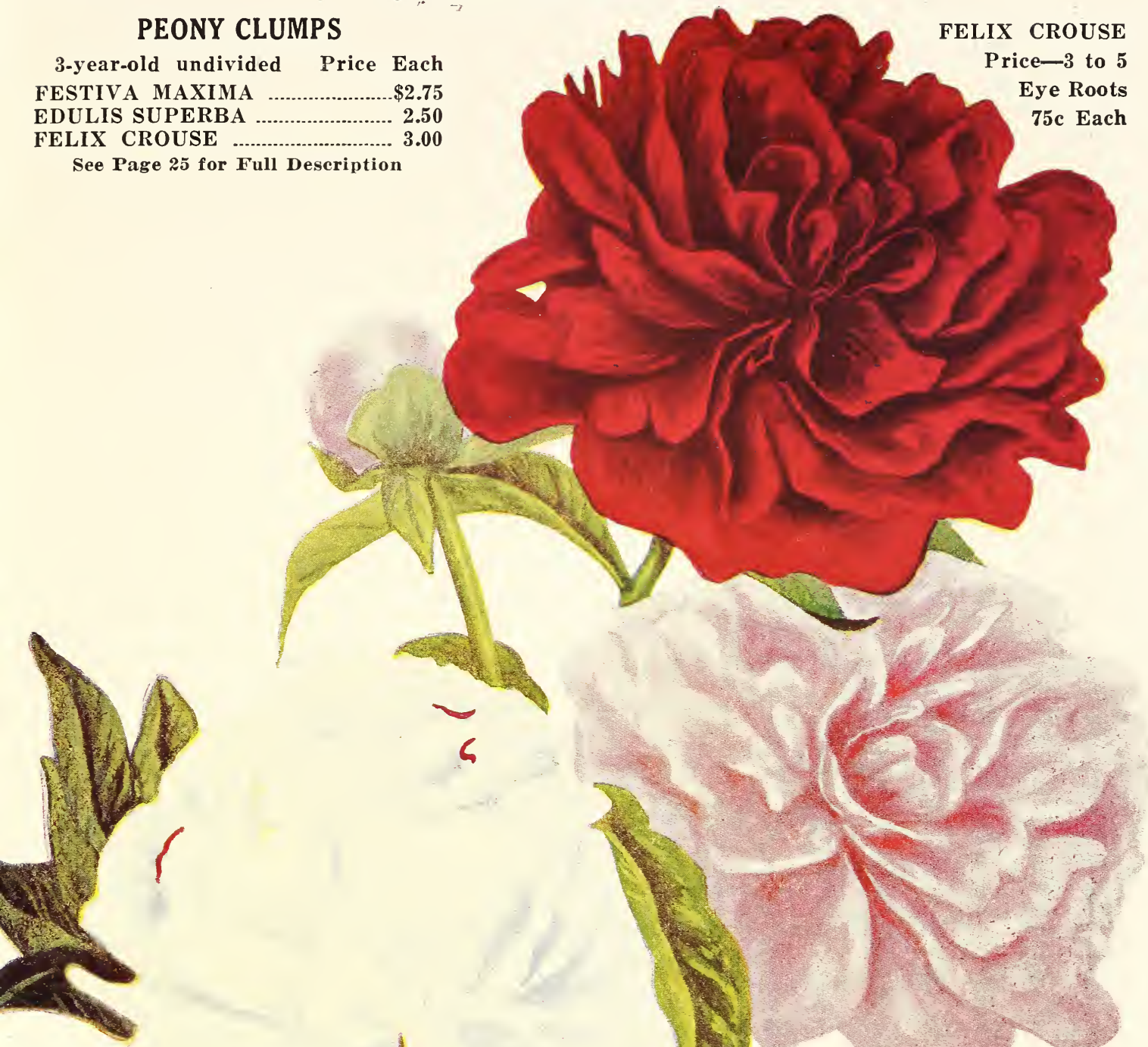


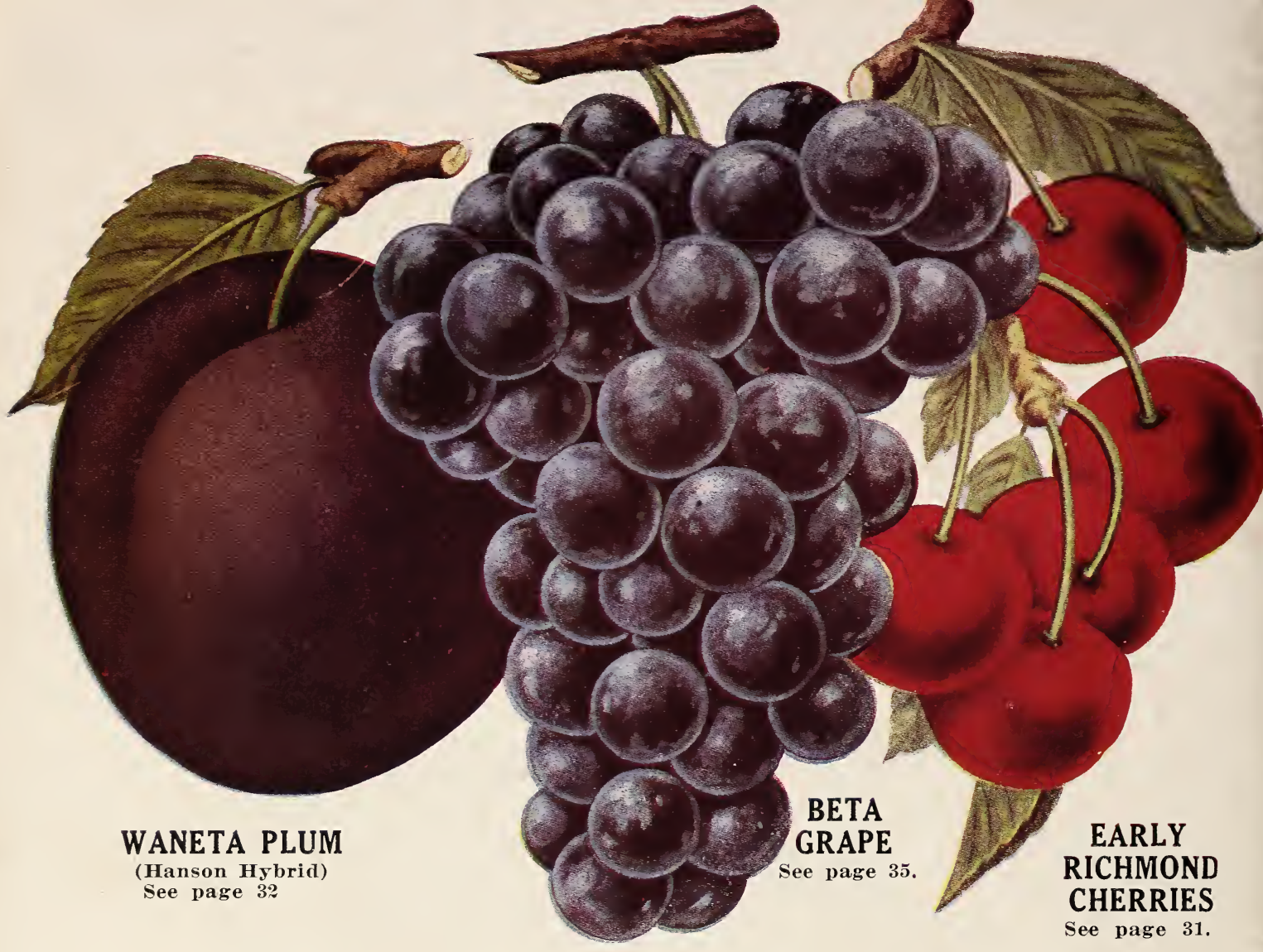

NORTHWEST'S THREE GREATEST FRUITS

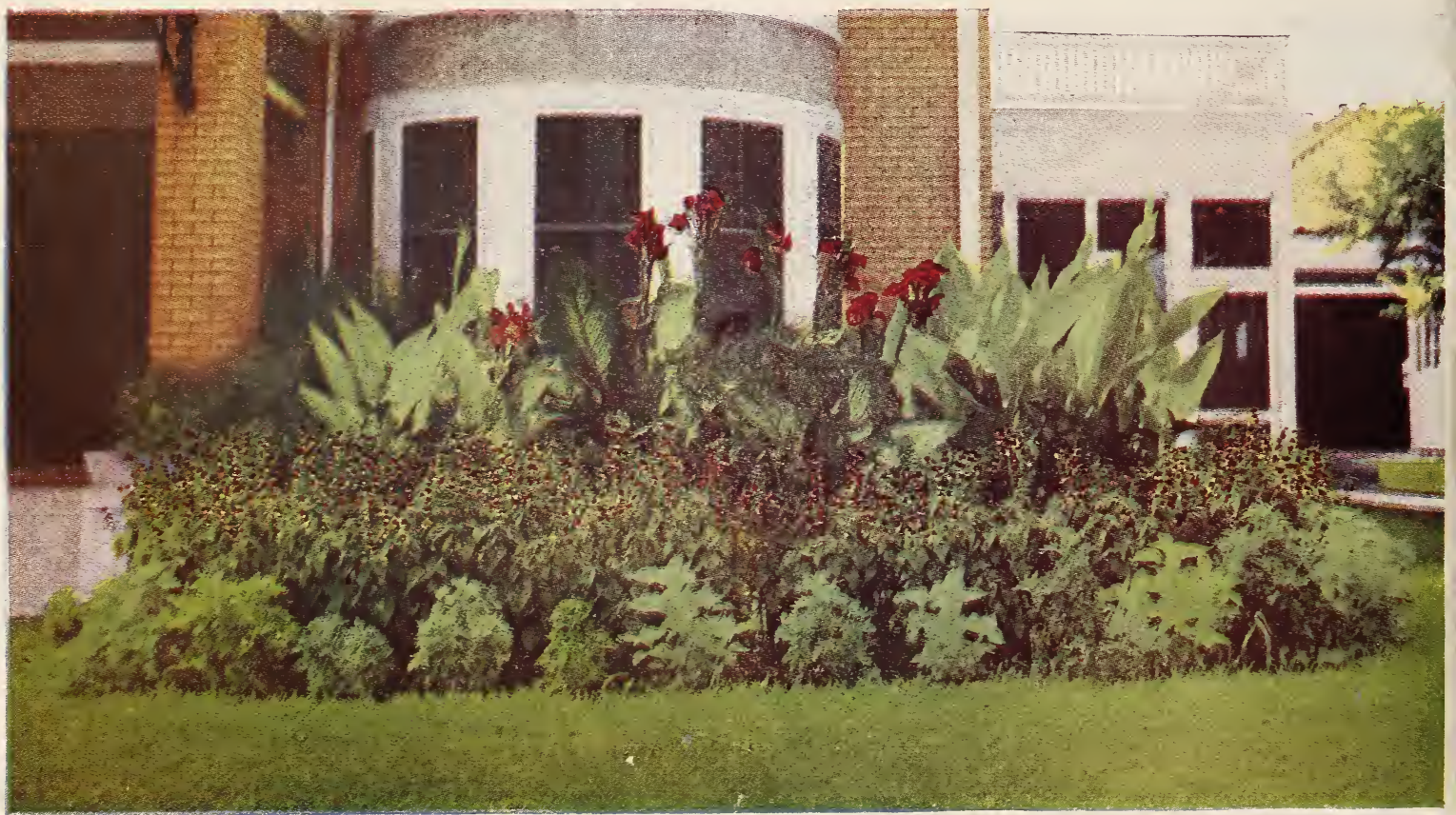

A Planting Which Appeals to Our Love of the Home Beautiful

MICHAEL SEED STORE, 316 Pearl Street, Sioux City, Ia.

Campbell Printing Co., Des Moines, Iowa 